\title{
Water quality changes over time in Upper Freeport and Pittsburgh coal mines in West Virginia
}

\author{
Ben M. Mack \\ West Virginia University
}

Follow this and additional works at: https://researchrepository.wvu.edu/etd

\section{Recommended Citation}

Mack, Ben M., "Water quality changes over time in Upper Freeport and Pittsburgh coal mines in West Virginia" (2008). Graduate Theses, Dissertations, and Problem Reports. 2634.

https://researchrepository.wvu.edu/etd/2634

This Thesis is protected by copyright and/or related rights. It has been brought to you by the The Research Repository @ WVU with permission from the rights-holder(s). You are free to use this Thesis in any way that is permitted by the copyright and related rights legislation that applies to your use. For other uses you must obtain permission from the rights-holder(s) directly, unless additional rights are indicated by a Creative Commons license in the record and/ or on the work itself. This Thesis has been accepted for inclusion in WVU Graduate Theses, Dissertations, and Problem Reports collection by an authorized administrator of The Research Repository @ WVU. For more information, please contact researchrepository@mail.wvu.edu. 


\title{
Water Quality Changes over Time in Upper Freeport and Pittsburgh Coal Mines in West Virginia
}

\author{
Ben M. Mack \\ Thesis submitted to the \\ Davis College of Agriculture, Forestry, \\ and Consumer Sciences at West Virginia University \\ in partial fulfillment of the requirements for \\ the degree of \\ Master of Science \\ In \\ Plant and Soil Sciences \\ Jeffrey Skousen, Ph.D, Chair \\ Louis McDonald, Ph.D \\ Dorothy Vesper, Ph.D \\ Division of Plant and Soil Sciences \\ Morgantown, WV \\ 2008
}




\title{
ABSTRACT \\ Water Quality Changes Over Time in Upper Freeport and Pittsburgh coal mines in West Virginia
}

\author{
Ben M. Mack
}

The objective of this research was to determine the changes in acidity, sulfate, iron, aluminum, and calcium concentrations over time in above-drainage, underground mines.

Water analyses were compiled from four sampling dates for two coal seams. Results for all sites showed declines in all parameters. Acidity decreases from the 40 sites were compared to three acidity decay curves. The data most closely matched the 5 percent decay curve. Acidity values from a different mine most closely matched the 10 percent decay curve during its first 12 years after closure. None of the five parameters showed significant relationships with either decade of mine closure or coal seam.

Five sites were more intensively sampled during March, May, and July 2007 to determine how flow and acidity changed over differing time periods. Flows were found to vary significantly between months. However, flow differences were not significant within the same month. Acidity followed a similar trend. 


\section{ACKNOWLEDGMENTS}

I would like to thank my professors and colleagues that helped me along my research path. My adviser, Jeff Skousen, was an invaluable source of information and support during the research and writing processes. His door was always open whenever I had a question. Louis McDonald and Dorothy Vesper provided very helpful information about the chemistry/geochemistry of AMD, as well as help with data presentation and analysis.

I would also like to thank Desta Fekedulegn for his help with the statistical part of the data analysis. His explanations of the statistical analyses performed were easy to understand and made the task of writing the discussion of the data much easier. Ken Stewart of the NRCCE Lab and Joan Wright of the Division of Plant and Soil Sciences aided in the analysis of water samples.

Lastly, I would like to thank my family. Their encouragement and love has supported me through the entire process of graduate school. The completion of this degree would not have been possible without them. 


\section{TABLE OF CONTENTS}

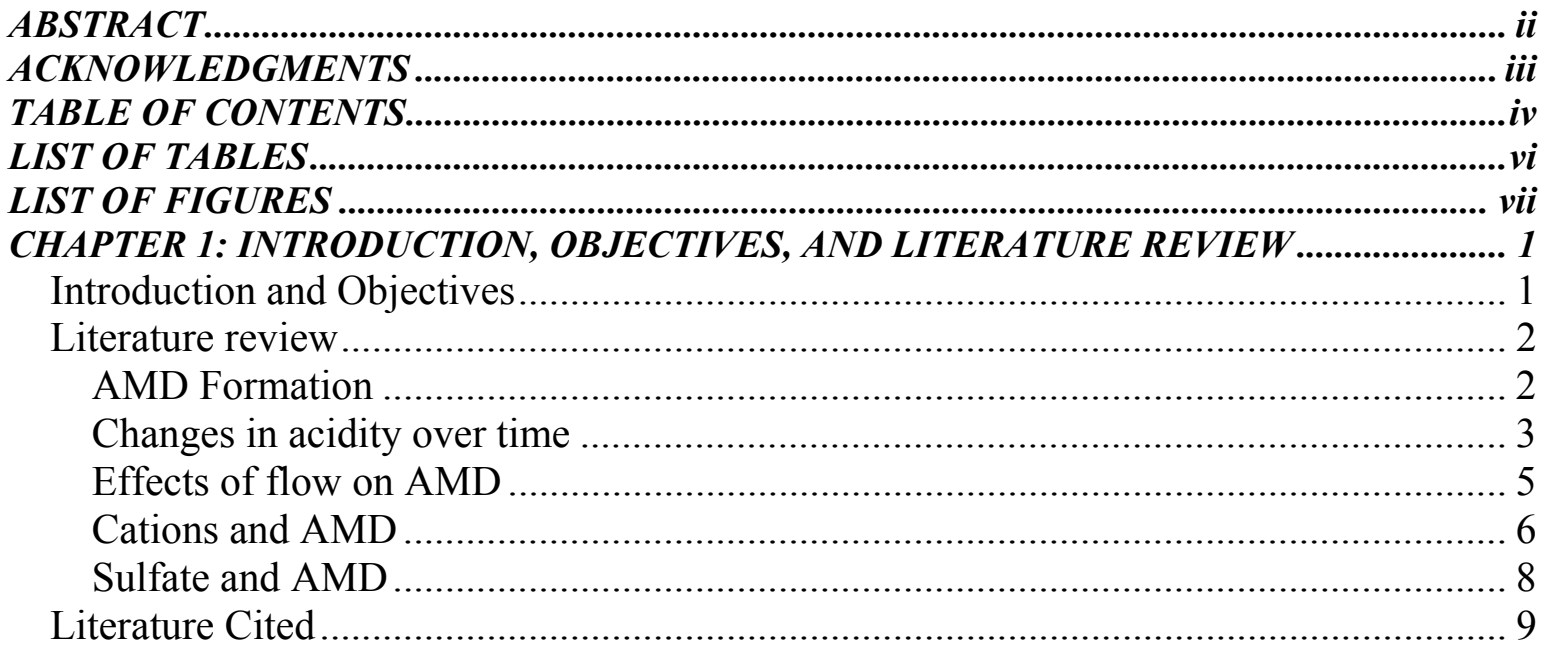

CHAPTER 2: CHANGES IN WATER QUALITY OF 40 ABOVE-DRAINAGE MINES OVER

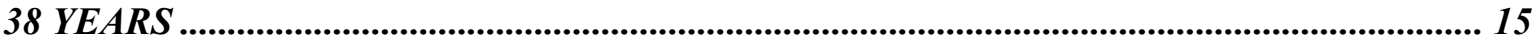

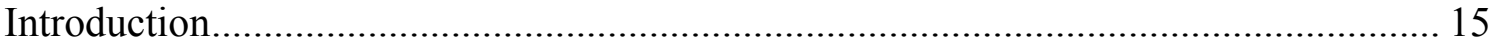

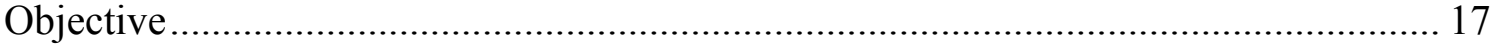

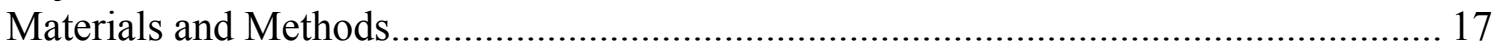

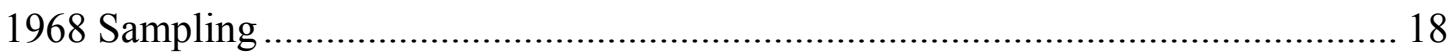

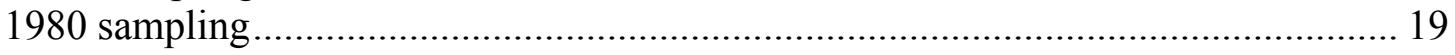

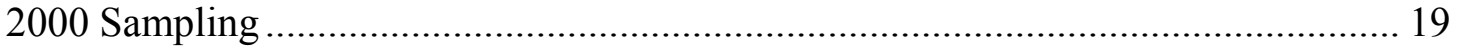

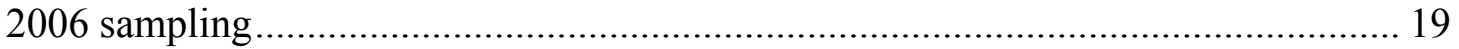

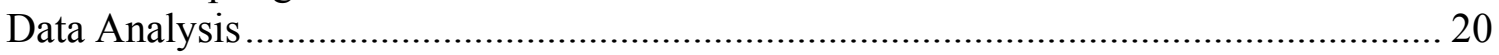

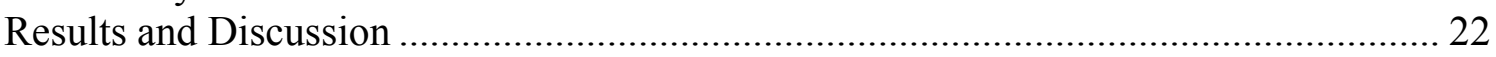

ANOVA was used to show significant differences for each parameter. Table 2-2

shows the results of the ANOVA for each parameter by both coal seam and decade of

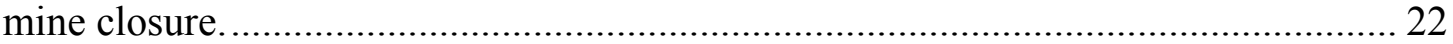

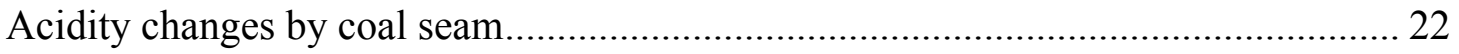

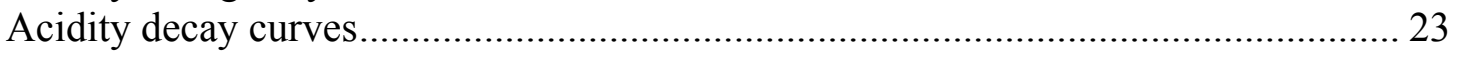

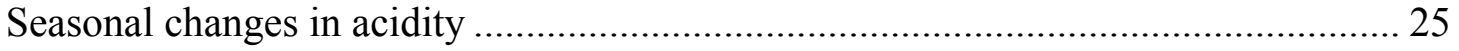

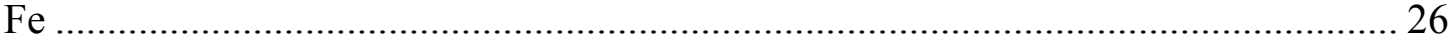

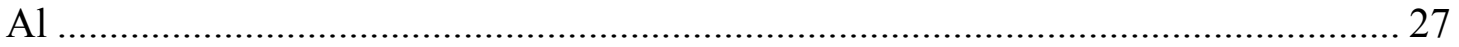

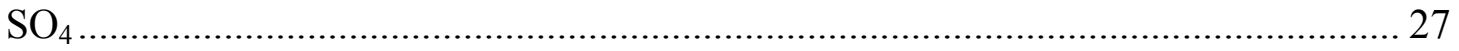

$\mathrm{Ca}$

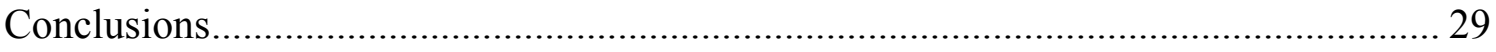

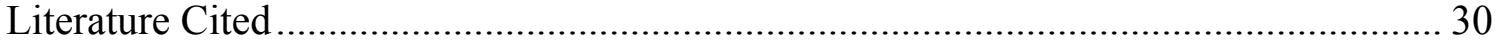

CHAPTER 3: INTENSIVE SAMPLING TO DETERMINE CHANGES IN FLOW AND

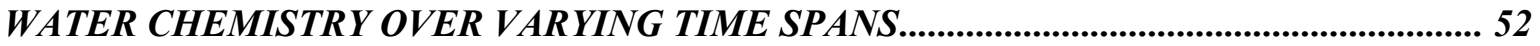

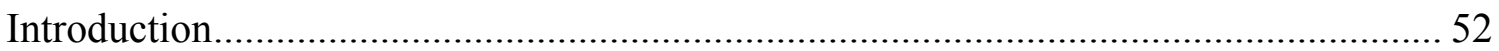

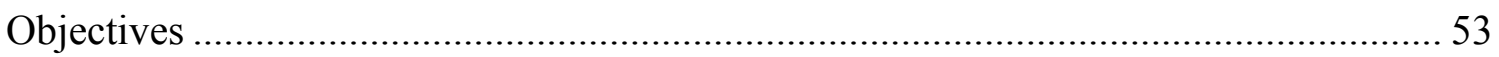

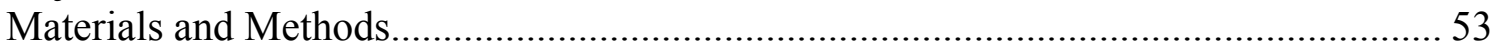

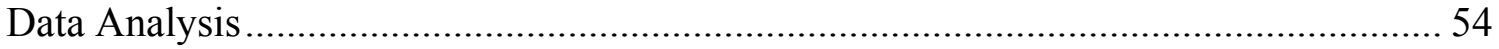

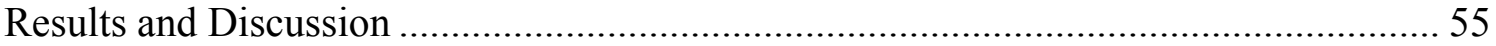

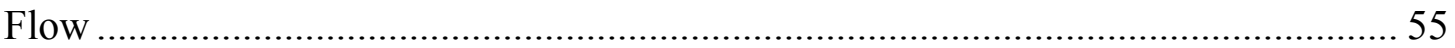




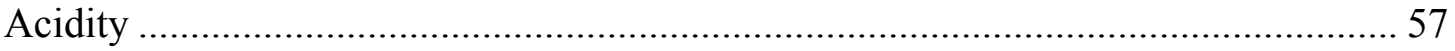

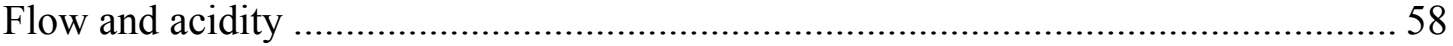

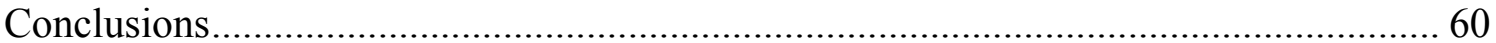

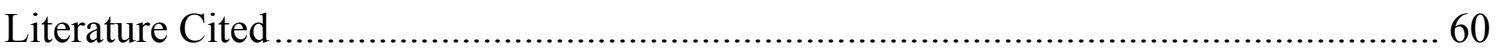

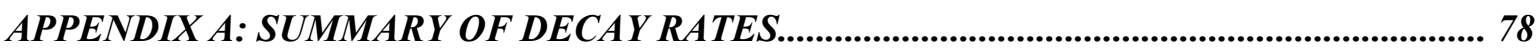

APPENDIX B: SIGNIFICANCE MATRICES FOR FLOW AND ACIDITY ......................... 79

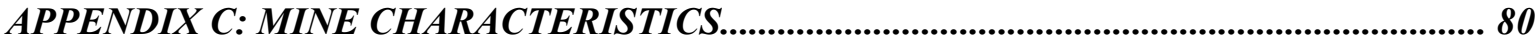

APPENDIX D: WATER CHEMISTRY FOR 40 MINE SITES................................................ 81 


\section{LIST OF TABLES}

Table 2-1. Number of samples taken at each site in each sampling year.

Table 2-2. ANOVA results for sampling dates, coal seam, and decade of closure. Interactions between dates and coal seams as well as dates and decades of closure are also shown. "Type III SS" is Type III Sum of Squares, which is used in the determination of the F value. All P values less than or equal to 0.10 are significantly different from the other class values for that class. ...

Table 2-3. Percent changes in acidity between sampling dates. UF=Upper Freeport coal seam.

Table 2-4. Mean concentrations for three different data groupings. The letters next to the values represent significant differences between values. For example, "a" is significantly different from "b."....

Table 2-5. Mean percent changes for three different data groupings. The letters next to the values represent significant differences between values. For example, "a" is significantly different from "b.".

Table 2-6. Mean $k$ values for three different data groupings. The $k$ value is equivalent to the slope of the data. The letters next to the values represent significant differences between values. For example, "a" is significantly different from " $b . "$

Table 2-7. Mean acidity concentrations for 4 different data groups. UF $=$ Upper Freeport, UF X 4= Upper Freeport sites sampled four times, and UF X 3= Upper Freeport sites sampled three times.

Table 2-8. Slope of linear trend lines for T\&T and the five other sites .39

Table 2-9. Mean acidity concentrations for T\&T and 5 other sites. The percent difference between the means is shown for each sample month.

Table 3-1. Descriptive statistics for flow and acidity .66

Table 3-2. Analysis of variance results for flow of five sites .66

Table 3-3. Mean flow and acidity values for entire sampling period by site. .66

Table 3-4. Mean flow and acidity values for each sampling month. .67

Table 3-5. Percent difference of mean flow values for five sites.

Table 3-6. Flow and acidity values for each week. All flow and acidity values are mean values....68

Table 3-7. Analysis of variance results for acidity of five sites. . .68

Table 3-8. Percent difference of mean acidity values for five sites .69 


\section{LIST OF FIGURES}

Figure 1-1. Difference between below-drainage and above-drainage mines. Underground mines are placed into one of these categories dependent upon their location relative to the local water table.

Figure 2-1. Map of the Cheat River watershed. Most AMD problems in the watershed are from Rowlesburg north to the river's terminus with the Monongahela River.

Figure 2-2. General stratigraphic column of part of the Pennsylvanian system. The Upper Freeport seam is located at the top of the Freeport formation in the Allegheny Group.................................41

Figure 2-3. General stratigraphic column of the Upper Pennsylvanian. The Pittsburgh coal seam is located at the bottom of the Monongahela Group .....................................................42

Figure 2-4. Acidity vs. time for six Pittsburgh sites. All sites showed decreased acidity over time. A line is used to connect sampling points to guide the eye .43

Figure 2-5. Acidity vs. time for 12 UF sites. All sites showed decreased acidity over time. A line is used to connect sampling points to guide the eye.

Figure 2-6. Acidity vs. time for 10 UF sites. All sites showed decreased acidity over time. A line is used to connect sampling points to guide the eye......

Figure 2-7. Acidity vs. time for 11 UF sites. All sites showed decreased acidity over time. A line is used to connect sampling points to guide the eye...... . .45

Figure 2-8. Acidity vs. time for 1 UF site. A line is used to connect sampling points to guide the eye.

Figure 2-9. Relative acidity $\left(\mathrm{C} / \mathrm{C}_{0}\right)$ vs. time since closure for three different decades of mine closure. Acidity values from the 1968, 1980, 2000, and 2006 sampling dates were divided by acidity values from $1968\left(\mathrm{C}_{0}\right)$ to obtain all points. . .46

Figure 2-10. Relative acidity $\left(\mathrm{C} / \mathrm{C}_{0}\right)$ vs. time since mine closure for two different coal seams. Acidity values from the 1968, 1980, 2000, and 2006 sampling dates were divided by acidity values from $1968\left(\mathrm{C}_{0}\right)$ to obtain all points. 46

Figure 2-11. Example of a site with linear acidity decline (Bull 2) and exponential acidity decline (Lynn 3)

Figure 2-12. Ideal acidity decay curves of 2,5 , and $10 \%$.

Figure 2-13. Relative acidity of six Pittsburgh sites vs. ideal decay curves. The decay curve of the Pittsburgh sites is closest to the $5 \%$ decay curve. 48

Figure 2-14. Relative acidity of 34 Upper Freeport sites vs. ideal decay curves. The decay curve of the Upper Freeport sites is closest to the 5\% decay curve. .48 
Figure 2-15. Decay rate values vs. time since mine closure for mines sampled four times. The low $\mathrm{R}^{2}$ value and the wide spread of the points indicate a poor relationship between decay rates and time since closure.

Figure 2-16. Decay rate values vs. time since mine closure for mines sampled three times. The low $\mathrm{R}^{2}$ value and the wide spread of the points indicate a poor relationship between decay rates and time since closure. 49

Figure 2-17. Relative acidity of T\&T \#2 vs. ideal decay curves. T\&T's decay curve is closest to the $10 \%$ decay curve

Figure 2-18. Mean acidity concentrations for T\&T and 5 other Upper Freeport sites. Month $1=$ March, Month 2= May, and Month 3= July. All sites showed increased acidity over time...

Figure 2-19. Relative Fe concentrations $\left(\mathrm{C} / \mathrm{C}_{0}\right)$ vs. time since mine closure for three decades of mine closure. Fe values from the 1968, 1980, 2000, and 2006 sampling dates were divided by Fe values from $1968\left(\mathrm{C}_{0}\right)$ to obtain all points.

Figure 2-20. Relative Fe concentrations $\left(\mathrm{C} / \mathrm{C}_{0}\right)$ vs. time since mine closure for two coal seams. Fe values from the 1968, 1980, 2000, and 2006 sampling dates were divided by Fe values from 1968 $\left(\mathrm{C}_{0}\right)$ to obtain all points. .48

Figure 2-21. Relative $\mathrm{Al}$ concentrations $\left(\mathrm{C} / \mathrm{C}_{0}\right)$ vs. time since mine closure for three decades of mine closure. Al values from the 1968, 1980, 2000, and 2006 sampling dates were divided by Al values from $1968\left(\mathrm{C}_{0}\right)$ to obtain all points. .48

Figure 2-22. Relative $\mathrm{Al}$ concentrations $\left(\mathrm{C} / \mathrm{C}_{0}\right)$ vs. time since mine closure for two coal seams. Al values from the 1968, 1980, 2000, and 2006 sampling dates were divided by Al values from 1968 $\left(\mathrm{C}_{0}\right)$ to obtain all points

Figure 2-23. Relative $\mathrm{SO}_{4}$ concentrations $\left(\mathrm{C} / \mathrm{C}_{0}\right)$ vs. time since mine closure for three decades of mine closure. $\mathrm{SO}_{4}$ values from the 1968, 1980, 2000, and 2006 sampling dates were divided by $\mathrm{SO}_{4}$ values from $1968\left(\mathrm{C}_{0}\right)$ to obtain all points.

Figure 2-24. Relative $\mathrm{SO}_{4}$ concentrations $\left(\mathrm{C} / \mathrm{C}_{0}\right)$ vs. time since mine closure for two coal seams. $\mathrm{SO}_{4}$ values from the 1968, 1980, 2000, and 2006 sampling dates were divided by $\mathrm{SO}_{4}$ values from $1968\left(\mathrm{C}_{0}\right)$ to obtain all points.

Figure 2-25. Relative Ca concentrations $\left(\mathrm{C} / \mathrm{C}_{0}\right)$ vs. time since mine closure for three decades of mine closure. Ca values from the 1968, 1980, 2000, and 2006 sampling dates were divided by Ca values from $1968\left(\mathrm{C}_{0}\right)$ to obtain all points. .50

Figure 2-26. Relative Ca concentrations $\left(\mathrm{C} / \mathrm{C}_{0}\right)$ vs. time since mine closure for two coal seams. Ca values from the 1968, 1980, 2000, and 2006 sampling dates were divided by Ca values from 1968 $\left(\mathrm{C}_{0}\right)$ to obtain all points.

Figure 3-1. Map of five intensively sampled sites represented by the orange dots. Site $1=$ Fickey 5 , Site 2=Fickey 6, Site 3=Fickey 7, Site 4= Muddy 11, and Site 5=Green 3. Sites 1-4 are in the Muddy Creek subwatershed and site 5 is in the Greens Run subwatershed. .66 
Figure 3-2. Range of flow for each sampling site and month. Each box represents the mid-range of the data while the black line in the middle of each box is the median. The lines extending from the box terminate at the minimum and maximum value of the data. M1=March, M2=May, and M3=July. F5, F6, and F7= Fickey 5, 6, and 7, M11= Muddy 11, and G3=Green 3. Fickey 5 and Muddy 11 were graphed separately to keep the graphs legible.

Figure 3-3. Relationship between percent variation and sample month for flow. All sites except Fickey 6 show an inverse relationship between the two parameters. Month $1=$ March, Month $2=$ May, and Month 3=July....

Figure 3-4. Comparison of long-term and short-term flow values. Each box represents the midrange of the data while the black line in the middle of each box is the median. The lines extending from the box terminate at the minimum and maximum value of the data. F5, F6, and F7= Fickey 5, 6, and 7, M11= Muddy 11, and G3=Green 3. LT=Long-term, ST=Short-term. "+"=outlier. .68

Figure 3-5. Range of acidity for each sampling site and month. Each box represents the mid-range of the data while the black line in the middle of each box is the median. The lines extending from the box terminate at the minimum and maximum value of the data. M1=March, M2=May, and M3=July. F5, F6, and F7= Fickey 5, 6, and 7, M11= Muddy 11, and G3=Green 3 .

Figure 3-6. Percent variation of acidity vs. sample month. All sites except Fickey 6 show a positive relationship between the two parameters. Month 1=March, Month 2=May, and Month $3=$ July.

Figure 3-7. Comparison of long-term and short-term acidity values. Each box represents the midrange of the data while the black line in the middle of each box is the median. The lines extending from the box terminate at the minimum and maximum value of the data. F5, F6, and F7= Fickey 5, 6, and 7, M11= Muddy 11, and G3=Green 3. LT=Long-term, ST=Short-term. "+"=outlier. .70

Figure 3-8. FA results for Fickey 5. Direction of lines indicates the loading of a parameter on the first or factor. Length of the lines indicates parameter magnitude. Acidity and flow show an opposite relationship to one another, as do $\mathrm{pH}$ and acidity..... .71

Figure 3-9. FA results for Fickey 6. Direction of lines indicates the loading of a parameter on the first or second component. Length of the lines indicates parameter magnitude. Acidity and flow show an opposite relationship to one another, as do $\mathrm{pH}$ and acidity. .71

Figure 3-10. FA results for Fickey 7. Direction of lines indicates the loading of a parameter on the first or second component. Length of the lines indicates parameter magnitude. Acidity and flow show an opposite relationship to one another, as do pH and acidity....

Figure 3-11. FA results for Muddy 11. Direction of lines indicates the loading of a parameter on the first or second component. Length of the lines indicates parameter magnitude. Acidity and flow show an opposite relationship to one another, as do $\mathrm{pH}$ and

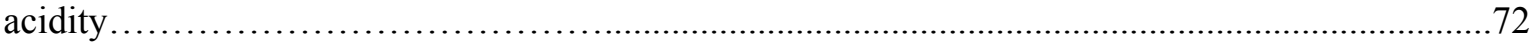


Figure 3-12. FA results for Green 3. Direction of lines indicates the loading of a parameter on the first or second component. Length of the lines indicates parameter magnitude. Acidity and flow show an opposite relationship to one another, as do $\mathrm{pH}$ and acidity.

Figure 3-13. Relationship between flow and acidity for Fickey 5. The slope of the regression line is negative, showing an inverse relationship between flow and acidity. ....

Figure 3-14. Relationship between flow and acidity for Fickey 6 . The slope of the regression line is negative, showing an inverse relationship between flow and acidity.

Figure 3-15. Relationship between flow and acidity for Fickey 7. The slope of the regression line is negative, showing an inverse relationship between flow and acidity. .74

Figure 3-16. Relationship between flow and acidity for Muddy 11. The slope of the regression line is negative, showing an inverse relationship between flow and acidity. .75

Figure 3-17. Relationship between flow and acidity for Green 3. The slope of the regression line is negative, showing an inverse relationship between flow and acidity..... .75

Figure 3-18. $\mathrm{Cu}$ and $\mathrm{Zn}$ concentrations and discharge for Richmond mine effluent at Iron Mountain, CA with rainfall history at nearby Shasta Dam. .76

Figure 3-19. Discharge, $\mathrm{Fe}, \mathrm{Zn}, \mathrm{Cu}$, and $\mathrm{Mn}$ concentrations in Contrary Creek during the rainstorm event of September 12-14, 1978 .... 


\section{CHAPTER 1: INTRODUCTION, OBJECTIVES, AND LITERATURE REVIEW}

\section{Introduction and Objectives}

Commercial mining of coal has taken place in West Virginia since the early 1800's (West Virginia's Office of Miner's Health, Safety, and Training, 2007). At this time, the majority of coal was mined using deep mining methods. Workers would mine the coal using picks and shovels, and it would be hauled from the mine by coal cars. Large-scale surface mining did not begin until the early 1900's. Even with the advent of mountain-top removal mining, the majority of coal extracted in WV is still mined using underground methods. It is estimated that about 610,000 ha (1.5 million ac) have been mined by underground methods (Bennett, 1991).

Acid Mine Drainage (AMD) is a major pollutant of surface waters in the Mid-Atlantic Region of the United States (US Environmental Protection Agency, 2006). The formation of AMD is a complex chemical and microbial process (Rose and Cravotta, 1998). The sulfur-bearing rocks that are associated with many types of coal become fractured during the mining process and are exposed to oxygen and water (Akcil and Koldas, 2006). The reaction is also catalyzed by certain types of bacteria, which greatly increases the rate of AMD production (Horan, 1999).

The Cheat River watershed in northeastern West Virginia has been heavily impacted by AMD pollution due to a long history of coal mining in the region. The Upper Freeport coal seam is found near the land surface in Preston County, which makes it accessible to deep and surface mining methods. The Pittsburgh seam was mined extensively for the same reason in Monongalia County. The geology associated with these two seams contributes to many of the impacts of mining that are seen in the watershed. Due to the Upper Freeport and Pittsburgh seams associations with pyritic rocks, mining of these seams typically releases a large amount of acidity and metals to receiving streams. The quality of these discharges may be affected by the amount of flow through the mine, as well as the age of the mine. Millions of dollars are spent to treat this water, making the quantification of flow's effects on metal concentrations and acidity, as well as changes in water quality over time, important areas of study (Skousen and Ziemkiewicz, 1996).

Flow and acidity in AMD-affected streams can be highly variable throughout the same watershed. These concentrations differ between mines due to hydrologic, chemical, and geologic factors within the mines. Some of these factors may include: different flow paths, dissimilar rates of reaction of the pyrite within the mine, various $\mathrm{pH}$ values, and different types and amounts of overburden surrounding the coal seam. This wide variation is important to understand because water treatment projects must be designed to handle periodic high flows and acidities over time. 
There were two main objectives of this research. The first of these was to determine changes in water quality of above-drainage, underground mines over time. The parameters that were studied to meet this objective were flow, acidity, $\mathrm{Fe}, \mathrm{Al}, \mathrm{Ca}$, and $\mathrm{SO}_{4}$. The second objective was to determine how flow and acidity change over various time periods for above-drainage, underground mines.

\section{$\underline{\text { Literature review }}$}

\section{AMD Formation}

AMD is one of the most prevalent sources of pollution in the watersheds of Appalachia today, affecting over 10,000 miles of streams (US Environmental Protection Agency, 1995). It is formed when pyrite-containing rocks are exposed to oxygen and water (US Environmental Protection Agency, 2006). AMD is characterized by high metal content (especially iron), as well as high acidity. These products of AMD formation are dissolved in water and then transported into receiving streams (Da Silva et al., 2006). The pyrite that forms AMD is oxidized in a series of reactions that can be summarized by the following chemical equations (Baker, 1975; Barnes and Romberger, 1968):

$$
\begin{aligned}
& \mathrm{FeS}_{2}+7 / 2 \mathrm{O}_{2}+\mathrm{H}_{2} \mathrm{O}=\mathrm{Fe}^{2+}+2 \mathrm{SO}_{4}{ }^{2-}+2 \mathrm{H}^{+} \\
& \mathrm{Fe}^{2+}+1 / 4 \mathrm{O}^{2}+\mathrm{H}^{+}=\mathrm{Fe}^{3+}+1 / 2 \mathrm{H}_{2} \mathrm{O} \\
& \mathrm{Fe}^{3+}+3 \mathrm{H}_{2} \mathrm{O}=\mathrm{Fe}(\mathrm{OH})_{3(\mathrm{~s})}+3 \mathrm{H}^{+} \\
& \mathrm{FeS}_{2(\mathrm{~s})}+14 \mathrm{Fe}^{3+}+8 \mathrm{H}_{2} \mathrm{O}=15 \mathrm{Fe}^{2+}+2 \mathrm{SO}_{4}{ }^{2-}+16 \mathrm{H}^{+}
\end{aligned}
$$

Due to the high acidity of most AMD discharges, $\mathrm{pH}$ is consequently low. The $\mathrm{pH}$ is defined as the hydrogen ion activity in a chemical solution (Buck et al., 2002). It is an essential parameter in the study of AMD because it strongly influences the solubility of metals in AMD (Geidel and Caruccio, 2000). Typically, both iron and aluminum are dissolved as AMD is discharged from underground mines. However, as the AMD mixes with higher-pH stream water, the $\mathrm{pH}$ of the AMD begins to rise and some of the acidity is neutralized. As the $\mathrm{pH}$ increases to $3.5, \mathrm{Fe}^{+3}$ begins to precipitate from the chemical solution and cover the bottom of the stream with a reddish-orange coating (Rose and Cravotta, 1998). As pH continues to increase above 3.5, aluminum also precipitates out of the chemical solution as a white solid at a $\mathrm{pH}$ of 4.5-5.5 (Nordstrom and Ball, 1986). 
The formation and composition of AMD is also influenced by the overburden surrounding the coal seam. The overburden can be characterized by Acid-Base Accounting, in which both the neutralization and the acidity potentials of the overburden are determined (Smith et al., 1974). Of particular importance to the acid-base characterization of overburden is the amount of sulfides associated with the coal, how these sulfides are distributed, and the type and size of pyrite particles present (Hill, 1968). The type of pyrite also affects metal concentration in the mine drainage, both

directly and indirectly. For example, the main source of iron in AMD comes from the pyrite itself, while aluminum comes from the breakdown of clay and other minerals due to acidic conditions (Druschel et al., 2004; Furrer et al., 2002).

The reaction rate of pyrite can also affect the composition of AMD. The kinetic rates of pyrite reaction have been well documented, and have been determined in the laboratory using artificial leaching methods (Lorenz and Tarpley, 1963; Renton et al., 1984). The speed with which pyrite oxidizes is heavily dependent upon the surface area of the reacting mineral (Caruccio, 1973). Pyrite with greater surface area will produce AMD more quickly due to a larger amount of available space for reactions to take place (Caruccio et al., 1977). Morin and Hutt (1994) found that the large majority of the surface area of waste rock is primarily made up of the fine size fraction $(<0.25 \mathrm{in})$, implying that waste rock will weather quickly and produce AMD at a faster rate due to its larger surface area.

Although the reaction rate of pyrite has been well-researched, the changes over time in pyrite reaction rates need further study. It is likely that pyrite reaction rates will differ according to the amount of time that has passed since mine closure. For example, changes in the levels of water and/or oxygen within the mine environment may occur after mine closure. Such a change in mine environments could alter the decay rate of pyrite.

\section{Changes in acidity over time}

Determination of changes in water quality over time from mined areas is very important. These changes are important to determine if the water can be treated adequately. Studying the longevity of AMD discharges will enable an estimation of how long current loading rates will continue, as well as the length of time that the discharge will violate water quality standards. Longevity also affects the type of treatment that can be used (active vs. passive).

Estimates of AMD longevity have been particularly difficult for underground mines. A large influence on the longevity of the drainage is the type of underground mine. There are two types; above-drainage and below-drainage (Fig. 1-1). Above-drainage mines are above the local water table. This type of mine will not fully flood because water will continually drain to the 
lowest point of the mine and discharge from an opening in the down-dip side of the mine. The voids in an above-drainage mine are continuously exposed to fluctuating levels of water and oxygen, which allows for continuous acid generation for decades.

The second mine type is below-drainage mines. These are situated below the local water table, and ground water must be pumped from the mine during active mining. After mining ceases and pumps are turned off, the mine void fills up with water and acidity production slows due to the exclusion of oxygen. Because of this, below-drainage mines generally are thought to have a limited amount of time in which they can produce AMD.

Changes in the water quality of abandoned mines can occur at different rates due to the type of mining that was performed. Investigations of surface mine discharges have shown that acidic water may be released at a consistent level for 10 to 20 years. After one or two decades, the metal salts generated during pyrite oxidation have been highly leached, which leads to a decrease in acidity (Meek, 1996). However, underground mines are more difficult to predict. In the United Kingdom, Younger (1997) estimated that acidic drainage may continue for 10 to 100 years. He contributed the longevity of AMD to two different types of acidity. The first of these types is the acidity that is generated from the initial filling of the mine void soon after mine closure (Type 1). This process adds a large amount of iron hydroxysulfates into the AMD solution. The second type of acidity is generated by the continued oxidation of pyrite as the water table fluctuates (Type 2). The AMD during the first 40 years after mine closure consists mainly of Type 1 acidity, while Type 2 acidity in AMD may be generated for hundreds of years. Type 1 acidity is related more to hydrologic factors, such as recharge rate, hydraulic conductivity, and mine volume, while Type 2 is related to the amount of pyrite available for oxidation and the reaction rate. The longevity of the AMD of a given discharge is dependent upon the amount of these two types of acidity (Younger, 1997).

Younger drew four major conclusions from his research. First, the worst discharge quality is seen within the first 40 years after mine closure. Second, the worst water quality occurs within 10 to 20 years after closure if there are large amounts of rainfall and few interconnected workings within the mine. Third, iron concentrations approach their asymptotic levels between 10 to 30 $\mathrm{mg} / \mathrm{L}$; and fourth, water quality is worse (higher iron and acidity concentrations) in mines with more pyrite and frequent water table fluctuations.

There have also been other theories proposed to determine the longevity of AMD discharges. The former British Coal Corporation used a rule of thumb stating that iron concentrations will decrease $50 \%$ for every time period required for flooding the void space in an underground mine. For example, if a mine void requires five years to fill up with water, iron 
concentrations should decrease by $50 \%$ every five years. This rule of thumb was only used for below-drainage mines (Glover, 1983).

Some researchers have stated that the worst pollution occurs in the first few decades after mine closure, but then settles to a lower level of impairment within 40 years. Wood et al. (1999) found that circum-neutral $\mathrm{pH}$ was obtained within 30 years after mine closure, while iron concentrations were $<40 \mathrm{mg} / \mathrm{L}$ after 40 years. Jones et al. (1994) found that underground mine discharges in Pennsylvania also showed improved quality after several decades since closure.

There has also been a great amount of research performed on mines that have fully flooded. Flooding of an underground mine slows and sometimes stops pyrite oxidation by excluding oxygen from the mine void (Vermeulen and Usher, 2006). Three mines in the Pittsburgh coal seam were studied by Lambert and Dzombak (2000). Water samples were taken in 1974 and 1999. Two of the three mines were flooded, below-drainage mines, while the third was an unflooded, abovedrainage mine. The first mine was closed in 1934, and showed a pH of 6.0 in 1974, and a pH of 6.4 and an iron concentration of $25 \mathrm{mg} / \mathrm{L}$ (down from $45 \mathrm{mg} / \mathrm{L}$ ) in 1999. The second mine closed in 1970, showing a pH increase from 3.1 to 5.9, and a Fe decrease of 50\% from 1974 to 1999 . From these results, the researchers determined that these two mines went from acidic to alkaline in 30 years from time of flooding. The above-drainage, unflooded mine also showed water quality improvements over the 25-year sampling time. However, these improvements were much less than the flooded mines, as the $\mathrm{pH}$ only increased from 3.0 to 3.5 .

Other research performed in this region has produced more information related to acidity changes over time. Brady et al. (1998) found that long-term water quality was tied to the geology surrounding the coal seam. The Monongahela Group, which contains the Pittsburgh coal seam, had the greatest maximum acidity value of all the geologic groups. Samples taken within this group had acidity concentrations that remained at a higher concentration for a longer period of time than other geologic groups.

\section{Effects of flow on AMD}

It is known that the flow from underground mines is affected by seasonal variations in rainfall. Typically, flows in this region of Appalachia are highest in winter and spring due to increased rain and snowfall. Rainfall recharges the groundwater, resulting in increased flows from discharge points. McDonough et al. (2005a) found that the M-59 discharge in the Uniontown Syncline of Pennsylvania followed a seasonal variation in discharge amounts, with lower flows in the summer months and the highest flows in the spring months. Wendland (2001) showed that groundwater reacted to rainfall within a month or within two months, depending on the season. 
Flow is a very important factor that can have a large influence on the effects of AMD to a receiving stream. Seasonal changes in flow will affect acidity and metal concentrations in AMD. One of the ways that flow can influence AMD is by the concept of the "spring flush." A study of the 51-hectare Majestic mine in Ohio by Pigati and Lopez (1999) supported this concept. They showed that larger flows in the spring scoured metal salts from the interior of the mine and "flushed" them out with the high flow events. This caused an increase in acidity and metal concentrations due to the higher flow. Desbarats and Dirom (2007), during their study of the Maya mine in British Columbia, found that small spikes in mine flow were found during the summer months after storm events. However, the highest spikes in metal concentrations in this mine was during the initial heavy rains in autumn. The Omega mine, an above-drainage mine in West Virginia, was sampled continuously for six years. Acidity values were consistently higher (roughly $4,500 \mathrm{mg} / \mathrm{L}$ ) between February and May when there were larger amounts of rainfall and higher flow values $(1.4 \mathrm{~L} / \mathrm{s})$. By contrast, June-January, with a lower average flow of $1.1 \mathrm{~L} / \mathrm{s}$, showed lower acidities of roughly 3,500 mg/L (Demchak et al., 2004). In general, above-drainage mines seem to support the "spring flush" theory.

In contrast, the "higher concentration at lower flow" theory suggests that acidity and metal concentrations will increase during times of decreased flow. This is because there is less water to dilute the metals dissolved in the water (Skousen and Ziemkiewicz, 1996). A study by Griffiths et al. (2001) at the Arnot mine in Pennsylvania found that acidity decreased as flow increased.

However, many small flushing events were found, which may have skewed the results. Stillings et al. (2007) found that the concentrations of the major metal elements (as measured by specific conductivity) in the Beatson Mine in Alaska decreased after major rain events. However, the dissolved concentrations of $\mathrm{Fe}$ and $\mathrm{Al}$ had increasing concentrations with higher flows. Lopez and Stoertz (2001) determined that mine chemistry stayed relatively constant over time, suggesting that the mine environment had approached the point of chemical equilibrium. They also found that following the first large flush after base flow, only a slight increase was seen in metal concentrations. Due to the contradicting nature of many of these studies, more research is needed to evaluate the effects of flow on water chemistry in underground mines.

\section{Cations and AMD}

The acidity in AMD comes from the addition of water and oxygen to pyrite, as well as the hydrolysis of metal ions (Drever, 1997; Totsche et al., 2006). In the mid-Atlantic region, the metal that occurs in the highest concentrations in AMD is iron (Fe). Sources of Fe in AMD are varied. Pyrite weathering is the primary process associated with AMD formation and the principal source 
of $\mathrm{Fe}$ in $\mathrm{AMD}$. However, as pyrite weathers, other secondary minerals are formed, including copiapite $\left.(\mathrm{Fe}, \mathrm{Mg}) \mathrm{Fe}_{4}\left(\mathrm{SO}_{4}\right)_{6}(\mathrm{OH})_{2}-20 \mathrm{H}_{2} \mathrm{O}\right)$, jarosite $\left(\mathrm{KFe}_{3}(\mathrm{SO} 4)_{2}(\mathrm{OH})_{6}\right)$, goethite $(\mathrm{FeO}(\mathrm{OH})$, and hematite $\left(\mathrm{Fe}_{2} \mathrm{O}_{3}\right)$. Weathering of these secondary minerals can be another source of $\mathrm{Fe}$ in AMD as they may solubilize due to changes in $\mathrm{pH}$ and oxidation conditions (Alpers et al., 1994). Other minerals that may form from Fe and add iron to the AMD solution are schwertmannite $\left(\mathrm{Fe}^{+3}{ }_{16} \mathrm{O}_{16} \mathrm{OH}_{12}\left(\mathrm{SO}_{4}\right)_{2}\right)$, ferrihydrite $\left(\mathrm{Fe}\left(\mathrm{OH}_{3}\right)\right.$, or other noncrystalline, amorphous masses.

However, these minerals are not well understood due to their poor structure, and their effects on AMD chemistry are not always known (Murad and Rojik, 2003).

In addition to mineral formation, flooding of an abandoned coal mine may also affect $\mathrm{Fe}$ concentrations in AMD. The exclusion of oxygen by water stops pyrite oxidation from occurring. Research conducted by McDonough et al. (2005b) showed an average decrease of $43 \%$ in Fe concentrations between two study areas in the Pittsburgh coal seam over the course of 25 years. They stated that the initial flush of metals after flooding of the mine was offset by infiltration of alkaline recharge water. The mine pool reached steady state in 25-30 years, which is also when the mine finished flooding. This caused both a increase in $\mathrm{pH}$ and a decrease in $\mathrm{Fe}$ and $\mathrm{SO}_{4}$ concentrations. In a study of a complex of underground mines in Butte, Montana, Metesh (2006) found that the mine complex flooded due to infiltration from the surface. A gradual improvement in water quality was noted after more water from the surface infiltrated into the mine complex.

$\mathrm{Al}$ is also one of the principal components of AMD. It is typically found in the kaolin family of clay minerals, as well as some secondary minerals, such as gibbsite $\left(\mathrm{Al}(\mathrm{OH})_{3}\right)$, boehmite $(\mathrm{AlO}(\mathrm{OH}))$, and amorphous $\mathrm{Al}$ hydroxides $\left(\mathrm{Al}(\mathrm{OH})_{3}\right)$. Silt particles may also increase the amount of $\mathrm{Al}$ found in an AMD solution due to dissolution of these particles when samples are acidified (Hedin, 2006). Al is found as a dissolved constituent of AMD when these minerals are dissolved in an acidic environment and are free to enter the chemical solution (Nordstrom et al., 2006).

$\mathrm{AMD}$ can be treated so that $\mathrm{Al}$ is removed from the chemical solution by mineral precipitation. Metal precipitation of Al begins at pH 4.5 (Skousen et al., 2000). The amount of Al present in the chemical solution determines the type of treatment that will be used. Some discharges have $\mathrm{Al}$ concentrations that are too great to be treated with passive remediation. For example, an anoxic limestone drain (ALD) cannot be used to treat a discharge with an Al concentration of greater than $25 \mathrm{mg} / \mathrm{L}$. The ALD will clog with metal precipitates and provide inadequate treatment (Hedin et al., 1994).

Calcium (Ca) may also be found in large concentrations in mine drainage. This is often the case in alkaline mine drainage, which is mine drainage that issues from overburden that contains 
more carbonate minerals than sulfides (Banks et al., 2002). These carbonate minerals can include calcite $\left(\mathrm{CaCO}_{3}\right)$, dolomite $\left(\mathrm{CaMg}\left(\mathrm{CO}_{3}\right)_{2}\right.$, and aragonite $\left(\mathrm{CaCO}_{3}\right)$, among others.

In the case of acidic mine drainage, the carbonate minerals are not present in sufficient quantities in the overburden. However, some acidic drainages may still have Ca concentrations of greater than $100 \mathrm{mg} / \mathrm{L}$. This Ca comes from dissolution of Ca-based minerals, such as gypsum $\left(\mathrm{CaSO}_{4} * 2 \mathrm{H}_{2} \mathrm{O}\right)$ and carbonates. Clay minerals, such as those from the vermiculite and smectite groups, may also provide a source of $\mathrm{Ca}$ (Schulze and Dixon, 2002). The Ca from these minerals is released into the AMD solution when the minerals are dissolved by low $\mathrm{pH}$ water in the mine void. Small amounts of Ca evaporites, such as anhydrite $\left(\mathrm{CaSO}_{4}\right)$, may also be left on the walls and ceiling of the mine as water levels decrease (McKee and Hannon, 1985). When the water level rises, these accumulated Ca salts may be washed off the walls and into the AMD solution, thus providing another source of $\mathrm{Ca}$ in the mine discharge. If the mine has limestone associated with the coal or if rock dust was applied for fire control during mining, Ca concentrations in the discharge may be elevated due to residual dust in the mine (Banks et al., 1997).

\section{Sulfate and AMD}

Sulfate $\left(\mathrm{SO}_{4}\right)$ is a common anion found in AMD. It is formed from the oxidation of pyrite and the subsequent mixture of these reaction products with water. This reaction is illustrated in the following chemical equation (Barnes and Romberger, 1968):

$\mathrm{FeS}_{2}+7 / 2 \mathrm{O}_{2}+\mathrm{H}_{2} \mathrm{O}=\mathrm{Fe}^{2+}+2 \mathrm{SO}_{4}{ }^{2-}+2 \mathrm{H}^{+}$

The treatment of $\mathrm{SO}_{4}$ can be accomplished in two steps. The first of these is by reducing $\mathrm{SO}_{4}$ to sulfides. This is often accomplished using an organic matter-based treatment system, such as an anaerobic wetland. The effectiveness of $\mathrm{SO}_{4}$ treatment by an anaerobic wetland can vary depending on the type of organic material used, as this influences the type and amount of bacteria available for $\mathrm{SO}_{4}$ reduction to $\mathrm{S}^{2-}$. A study performed by Zagury et al. (2006) tested six different organic materials (maple wood chips, sphagnum peat moss, leaf compost, conifer compost, poultry manure, and conifer sawdust) to determine which one promoted the greatest amount of $\mathrm{SO}_{4}$ reduction to $\mathrm{S}^{2-}$. A mixture of the six materials gave the greatest amount of $\mathrm{SO}_{4}$ reduction to $\mathrm{S}^{2-}$, while the poultry manure reduced the least amount of $\mathrm{SO}_{4}$ to $\mathrm{S}^{2-}$. Kalin et al. (2006) showed that photosynthesis within the water column can also influence the amount of $\mathrm{SO}_{4}$ reduced to $\mathrm{S}^{2-}$ by sediment-bound bacteria. Thermodynamic chemical reduction of Fe, when combined with $\mathrm{H}_{2} \mathrm{~S}$ 
from $\mathrm{SO}_{4}$ reduction, promotes more alkalinity production and a faster rate of $\mathrm{SO}_{4}$ loss in the AMD solution.

The second step of treating $\mathrm{SO}_{4}$ occurs when $\mathrm{SO}_{4}$ reduces to sulfides, which then form complexes with metals in the AMD solution. Surface complexes can be formed when sulfides adsorb on to Fe-hydroxide precipitates (Paul et al., 2006). These solids then precipitate out of the chemical solution at a certain $\mathrm{pH}$ value that is dependent on the materials that make up the complex (Lenter et al., 2002). Sierra-Alvarez et al. (2006) used synthetic AMD with a pH of 4.0 and high metal concentrations and found that the effluent of treated $\mathrm{AMD}$ in a $\mathrm{SO}_{4}$-reducing bioreactor had a $\mathrm{pH}$ of 7.1 , as well as a $99 \%$ metal removal rate due to metal-sulfide complexation and mineral precipitation reactions.

Changes in cation and anion concentrations over time are highly dependent upon the mineralogy and geochemistry of a mine. Previous research has shown that individual mines differ widely in both of these respects. However, by comparing mines with similar characteristics, such as coal seam mined or mine type, patterns in cation and anion concentrations over time may be found.

\section{$\underline{\text { Literature Cited }}$}

Akcil, A. and Koldas, S. 2006. Acid Mine Drainage (AMD): Causes, treatment, and case studies. Journal of Cleaner Production 14 (12-13): 1139-1145.

Alpers, C.N., Blowes, D.W., Nordstrom, D.K., and Jambor, J.L. 1994. Secondary minerals and acid mine water chemistry. Chapter 9. p. 247-270. In Short Course Handbook on Environmental Geochemistry of Sulfide Mine-Wastes. Volume 22. Mineralogical Association of Canada, Nepean, Ontario, Canada

Baker, M. 1975. Inactive and abandoned underground mines- water pollution prevention and control. EPA-440/9-75-007. USEPA, Washington D.C.

Banks, D., Younger, P.L., Arnesen, R.-T., Iversen, E.R., and Banks, S.B. 1997. Mine-water chemistry: The good, the bad, and the ugly. Environmental Geology 32 (3): 157-174.

Banks, D., Parnachev, V.P., Frengstad, B., Holden, W., Vedernikov, A.A., and Karnachuk, O.V. 2002. Alkaline mine drainage from metal sulphide and coal mines: Examples from Svalbard and Siberia. Geological Society of London, Special Publications 198: 287-296.

Barnes, H.L., and Romberger, S.B. 1968. Chemical aspects of acid mine drainage. Journal of Water Pollution Control Federation 40: 371-384.

Bennett, L. 1991. Abandoned mines: report from WV. EPA Journal 17 (5): 16-18. 
Brady, K.B., Hornberger, R.J., and Fleeger, G. 1998. Influence of geology on post-mining water quality: northern Appalachian Basin. pp. 8-1 to 8-92 In Coal Mine Drainage Prediction and Pollution Prevention in Pennsylvania. PA Department of Environmental Protection. Harrisburg, PA.

Buck, R.P., Rondinini, S., Covington, A.K., Baucke, F.G.K., Brett, C.M.A., Camoes, M.F., Milton, M.J.T., Mussini, T., Naumann, R., Pratt, K.W., Spitzer, P., and Wilson, G.S. 2002. Measurement of pH: Definition, standards, and procedures. Pure Appl. Chem. 74 (11): 2169-2200.

Caruccio, F.T. 1973. Estimating the acid potential of coal mine refuse. p.197-205. In The ecology of resource degradation and renewal. Blackwell Sci. Publishing. London, England.

Caruccio, F.T., Ferm, J.C., Horne, J., Geidel, G., and Baganz, B. 1977. Paleoenvironment of coal and its relation to drainage quality. EPA/600/7-77/067. U. S. Environmental Protection Agency, Washington DC. 108p.

Da Silva, E.F., Reis, P., Fonseca, E.C., Matos, J.X., Barrosinho, J., and Santos Oliveira, J.M. 2006. Interaction of acid mine drainage with waters and sediments at the Corona stream, Lousal mine (Iberian Pyrite Belt, Southern Portugal). Environmental Geology 50(7): 1001-1013.

Demchak, J, Skousen, J., and McDonald, L.M. 2004. Longevity of acid discharges from underground mines located above the regional water table. Journal of Environmental Quality 33: 656-658.

Desbarats, A.J. and Dirom, G.C. 2007. Temporal variations in the chemistry of circum-neutral drainage from the 10-Level portal, Myra Mine, Vancouver Island, British Columbia. Applied Geochemistry 22 (2): 415-435.

Drever, J. 1997. The Geochemistry of Natural Waters: Surface and Groundwater Environments. Upper Saddle River, NJ, Prentice Hall, p. 306-309.

Druschel, G., Barker, B., Gihring, T., and Banfield, J. 2004. Acid mine drainage biogeochemistry at Iron Mountain, California. Geochemical Transactions 5 (2):13.

Furrer, G., Phillips, B.L., Ulrich, K.-U., Pothig, R., and Casey, W.H. 2002. The origin of Al flocs in polluted streams. Science 297: 2245-2247.

Geidel, G. and Caruccio, F.T. 2000. Geochemical factors affecting coal mine drainage quality. p.108. In Reclamation of Drastically Disturbed Lands. Agronomy Monogr. 41. ASA, Madison, WI.

Glover, H.G. 1983. Mine water pollution-An overview of problems and control strategies in the United Kingdom, Water Science Technology 15: 59-70.

Griffiths, J.C., Hornberger, R.J., Miller, K., and Smith, M.W.. 2001. Statistical analysis of abandoned mine drainage in the assessment of pollution load ("The Griffiths Report"). EPA- 821B-01-014. 268 p. National Technical Information Service \# PB2002-104395, Springfield, VA.

Hedin, R.S, Nairn, R.W., and Kleinmann, R.L.P. 1994. Passive treatment of coal mine drainage. US Department of the Interior Bureau of Mines Information Circular 9389. Pittsburgh, PA. 
Hedin, R. S. 2006. The use of measured and calculated acidity values to improve the quality of mine drainage datasets. Mine Water and the Environment 25: 146-152.

Hill, R. 1968. Mine drainage treatment: state of the art and research needs. US Department of the Interior, Federal Water Pollution Control Administration. Cincinnati, $\mathrm{OH}$.

Horan, J. 1999. Thiobacillus ferrooxidans. www.mines.edu/fs_home/jhoran/ch126/thiobaci.htm. Accessed 8/16/06. Updated 12/3/99.

Jones, P.M., Mulvay, S.M., and Fish, D. 1994. The role of sulfate and ionic strength on the shift from acid to alkaline mine drainage in southwest Pennsylvania. pp. 289-295 In:

Proceedings of the International Land Reclamation and Mine Drainage Conference and the Third International Conference of the Abatement of Acid Mine Drainage. Vol. 2: Mine Drainage. US Bureau of Mines Special Publication SP 06B-94.

Kalin, M., Fyson, A., and Wheeler, W. 2006. The chemistry of conventional and alternative treatment systems for the neutralization of acid mine drainage. Science of the Total Environment 366 (2-3): 395-408.

Lambert, D.C., and Dzombak, D.A. 2000. Evaluation of natural amelioration of acidic deep mine discharges in the Uniontown Syncline, Pennsylvania. In Proceedings of the $21^{\text {st }}$ West Virginia Surface Mine Drainage Task Force Symposium, April 4-5, 2000, Morgantown, WV.

Lenter, C.M., McDonald, L.M., Skousen, J.G., and Ziemkiewicz, P.F. 2002. The effects of sulfate on the physical and chemical properties of actively treated acid mine drainage floc. Mine Water and the Environment 21: 114-120.

Lopez, D.L. and Stoertz, M.W. 2001. Chemical and physical controls on water discharged from abandoned coal mines. Geochemistry: Exploration, Environment, Analysis 1: 51-60.

Lorenz, W. C. and Tarpley, E.C. 1963. Oxidation of Coal Mine Pyrites, US Bureau of Mines R.I. 6247, 13 p. Pittsburgh, PA.

McDonough, K., Lambert, D.C., Mugunthan, P., and Dzombak, D.A. 2005a. Processes governing flow and chemical characteristics of discharges from free-draining, underground coal mines. Journal of Environmental Engineering 131 (10): 1361-1368.

McDonough, K., Lambert, D.C., Mugunthan, P., and Dzombak, D.A. 2005b. Hydrologic and geochemical factors governing chemical evolution of discharges from an abandoned, flooded underground coal mine network. Journal of Environmental Engineering 131 (10): 643-650.

McKee, D. M. and Hannon, P.J. 1985. The hydrological environment of the Gays River mine. International Journal of Mine Water 4 (2): 13-34.

Meek, F.A. 1996. Evaluation of acid prevention techniques used in surface mining. Chapt.11. In: Acid Mine Drainage Control and Treatment. National Mine Land Reclamation Center, Morgantown, WV.

Metesh, J.J. 2006. Using a water balance to determine the source of water in the flooding underground mine workings of Butte. Mine Water and the Environment 25: 108-113. 
Morin, K. A. and Hutt, N.M. 1994. An empirical technique for predicting the chemistry of water seeping from mine-rock piles. International Land Reclamation and Mine Drainage Conference and Third International Conference on the Abatement of Acidic Drainage, Pittsburgh, PA, USA, U. S. Bureau of Mines Special Publication SP 06A-94, p. 12-19.

Murad, P., and Rojik, P. 2003. Iron-rich precipitates in a mine drainage environment: Influence of $\mathrm{pH}$ on mineralogy. American Mineralogist 88: 1915-1918.

Nordstrom, D., and Ball, J. 1986. The geochemical behavior of aluminum in acidified surface waters. Science, New Series 232 (4746): 54-56.

Nordstrom, D.K., Ball, J.W., and McCleskey, R.B. 2006. Geochemistry of aluminum in surface waters affected by acid rock drainage. In 2006 Geological Society of America annual meeting, Philadelphia, PA. 22 Oct.-25 Oct. 2006.

Paul, K.W., Kubicki, J.D., and Sparks, D.L. 2006. Quantum chemical calculations of sulfate adsorption at the Al- and Fe-(hydr)oxide-H2O interfaces estimation of Gibbs free energies. Environ. Sci. Technol 40: 7717-7724.

Pigati, E., and Lopez, D. 1999. Effect of subsidence on recharge at abandoned coal mines generating acidic drainage: the Majestic mine, Athens County, OH. Mine Water and the Environment 18 (1): 45-66.

Renton, J.J., Stiller, A.H., and Rymer, T. 1984. Quantitative determination of the acid producing potential of toxic overburden. Symposium on Surface Mining \& Water Quality, Morgantown, WV, USA, West Virginia Surface Mining \& Reclamation Association.

Rose, A.W., and Cravotta, C.A.III. 1998. Chapter 1: Geochemistry of coal mine drainage In Coal mine drainage prediction and pollution prevention in Pennsylvania: 1-1 to 1-21. PA Department of Environmental Protection. Harrisburg, PA.

Schulze, D. G. and Dixon, J.B., Ed. 2002. Soil Mineralogy with Environmental Applications. SSSA Book Series 7. Madison, WI, Soil Science Society of America.

Sierra-Alvarez, R., Karri, S., Freeman, S., and Field, J.A. 2006. Biological treatment of heavy metals in acid mine drainage using sulfate reducing bioreactors. Water Science Technology 54(2): 179-185.

Skousen, J., and Ziemkiewicz, P. 1996. Acid Mine Drainage Control and Treatment. National Research Center for Coal and Energy, West Virginia University, Morgantown, WV.

Skousen, J., Ziemkiewicz, P., and Sexstone, A. 2000. Acid mine drainage control and treatment. p. 143. In Reclamation of Drastically Disturbed Lands. Agronomy Monogr. \#41. ASA, Madison, WI.

Smith, R. M., Grube, W.E., Arkle, T.A., and Sobek, A.A. 1974. Mine spoil potentials for soil and water quality. USEPA 670274070. 320 p. National Technical Information Service \# PB-237 525, Springfield, VA.

Stillings, L.L., Foster, A.L., Koski, R., Munk, L., and Shanks, W.C. 2007. Temporal variation and the effects of rainfall on metals flux from the historic Beatson mine, Prince William Sound, Alaska, USA. Applied Geochemistry 23(2): 255-278. 
Totsche, O., Fyson, A., Kalin, M., and Steinberg, C.E.W. 2006. Titration Curves:

A Useful Instrument for Assessing the Buffer Systems of Acidic Mining Waters. Environmental Science Pollution Research 13 (4): 215-224.

US Environmental Protection Agency. 1995. Streams with fisheries impacted by acid mine drainage in $\mathrm{MD}, \mathrm{OH}, \mathrm{PA}, \mathrm{VA}$, and WV. Wheeling, WV.

US Environmental Protection Agency. 2006. Mid-Atlantic integrated assessment of acid mine drainage. http://www.epa.gov/maia/html/AMD_issue.html. Accessed 8/15/06, Updated 3/3/06.

Vermeulen, P., and Usher, B.H. 2006. Sulphate generation in South African underground and open cast collieries. Environmental Geology 49(4): 552-569.

Wendland, W.M. 2001. Temporal responses of surface water and groundwater to precipitation in Illinois. Journal of American Water Resources Associations 37: 685-693.

West Virginia Office of Miners Health, Safety, and Training. 2007. A Brief History of Coal and Safety Enforcement in West Virginia. http://www.wvminesafety.org/HISTORY.HTM. Updated 07/26/2007, Accessed 07/30/2007.

Wood, S.C., Younger, P.L., and Robins, N.S. 1999. Long-term changes in the quality of polluted minewater discharges from abandoned underground coal workings in Scotland. Quarterly J. Engineering Geology 32: 69-79.

Younger, P. L. 1997. The longevity of minewater pollution: a basis for decision-making. The Science of the Total Environment 194-195: 457-466.

Zagury, G.J., Kulnieks, V.I., and Neculita, C.M. 2006. Characterization and reactivity assessment of organic substrates for sulphate-reducing bacteria in acid mine drainage treatment. Chemosphere 64 (6): 944-954. 


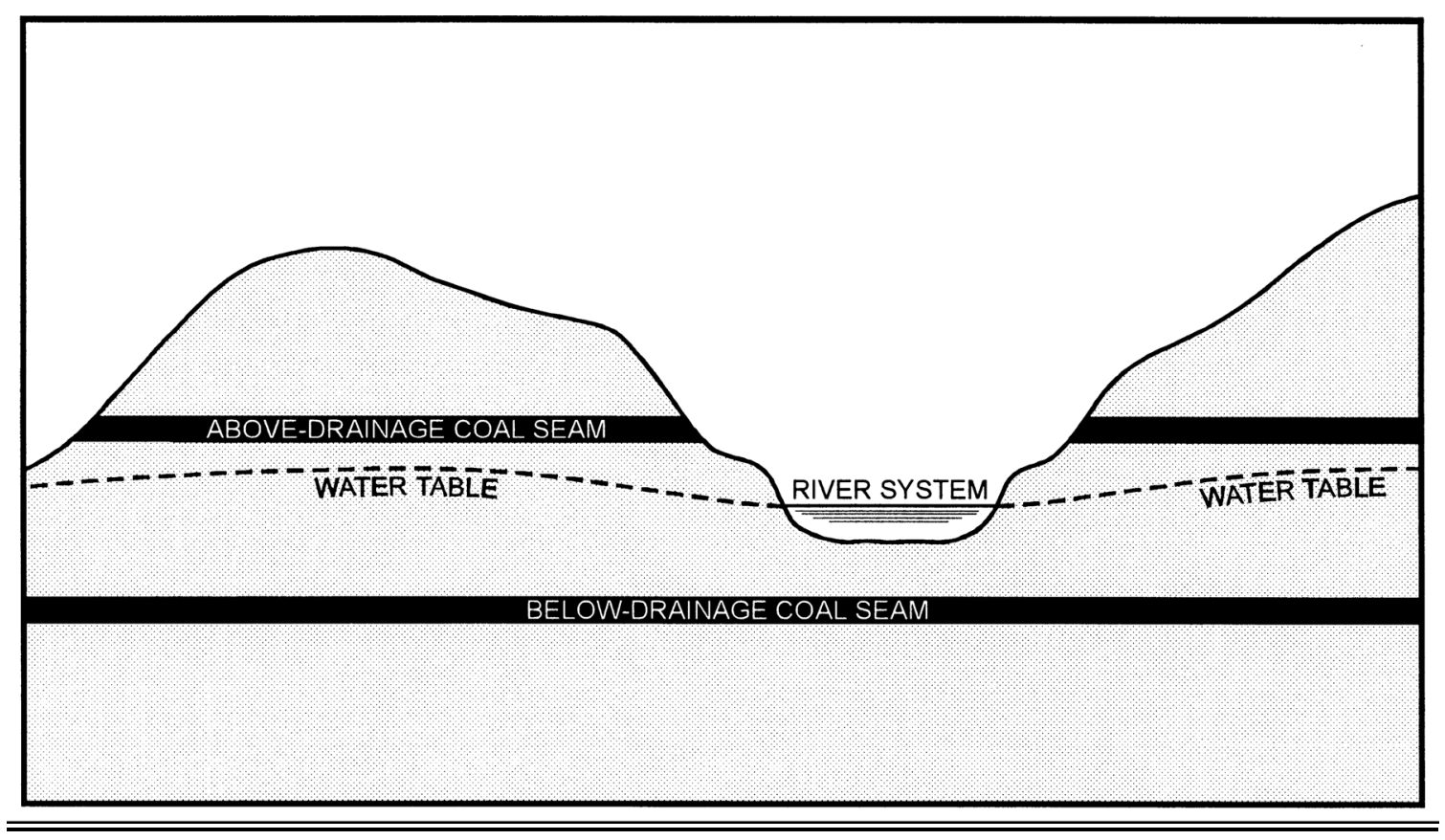

Fig. 1-1. The difference between above and below-drainage mines. Underground mines are placed into one of these categories dependent upon their location relative to the local water table (Figure taken from Demchak et al., 2004). 


\section{CHAPTER 2: CHANGES IN WATER QUALITY OF 40 ABOVE- DRAINAGE MINES OVER 38 YEARS}

\section{$\underline{\text { Introduction }}$}

Extensive underground mining has taken place in West Virginia since the late 1800s (West Virginia's Office of Miner's Health, Safety, and Training, 2007). The total extent of underground mining in WV is unknown, however, Bennett (1991) estimated that about 610,000 ha (1.5 million ac) have been mined by underground methods. This legacy of mining has influenced groundwater quality. The greatest impact on water quality from underground mines is Acid Mine Drainage (AMD).

AMD is a major pollutant of surface waters in the Mid-Atlantic Region of the United States (US EPA, 2006). The formation of AMD is a complex chemical and microbial process (Rose and Cravotta, 1998). The sulfur-bearing rocks that are associated with many types of coal become fractured during the mining process and are exposed to oxygen and water (Akcil and Koldas, 2006). The reaction is also catalyzed by certain types of bacteria, which greatly increases the rate of AMD production (Horan, 1999).

The quality of AMD from underground mines appears to change over time. Much of the published research on the subject of AMD change with time shows that acidity concentrations decline over time. However, several factors influence how quickly this decrease occurs. Younger (1997) estimated that acidic drainage may continue for 10 to 100 years for underground mines. However, overall acidity decreases over time as the mine void fills with water, which eliminates the exposure of pyrite to oxygen. These decreases in acidity were tied to the amount of rainfall, amount of interconnected workings, initial metal concentrations, and initial amount of pyrite available for oxidation (Younger, 1997). Underground mine discharges in Pennsylvania were also found to improve several decades after mine closure (Jones et al., 1994).

Three mines in the Pittsburgh coal seam were studied by Lambert and Dzombak (2000). Water samples were taken in 1974 and 1999. Two of the three mines were flooded, below-drainage mines, while the third was an unflooded, above-drainage mine. The first mine was closed in 1934, and showed a pH of 6.0 in 1974, and a pH of 6.4 and an iron concentration of $25 \mathrm{mg} / \mathrm{L}$ (down from $45 \mathrm{mg} / \mathrm{L}$ ) in 1999. The second mine closed in 1970, showing a pH increase from 3.1 to 5.9 , and a Fe decrease of $50 \%$ from 1974 to 1999 . From these results, the researchers determined that these two mines went from acidic to alkaline in 30 years from time of flooding. The above-drainage, unflooded mine also showed water quality improvements over the 25 -year sampling time. 
However, these improvements were much less than the flooded mines, as the $\mathrm{pH}$ only increased from 3.0 to 3.5 .

Brady et al. (1998) found that long-term water quality was tied to the geology surrounding the coal seam. The Monongahela Group, which contains the Pittsburgh coal seam, had the greatest maximum acidity value of all the geologic groups. Samples taken within this group had acidity concentrations that remained at a higher concentration for a longer period of time than other geologic groups.

Another factor that affects mine water chemistry is the coal seam that is mined (Ruppert and Rice, 2000). Each coal seam has specific chemical and physical qualities, such as sulfur content in the coal, which can influence the quality of the drainage from the mine.

Another factor that contributes to changes in water quality over time is due to changes in the reaction rate of pyrite. As pyrite oxidation slows, less acidity is produced. Changes in reaction rate often occur due to less infiltration of either water or oxygen into the mine. Water infiltration may be slowed due to roof collapses within the mine, surface compaction of soil, filling of cracks from the surface to the mine, or lack of rainfall. The amount of oxygen available for reaction within the mine may be related to reclamation practices such as wet seals, as well as natural portal collapse.

The reaction rate of pyrite and subsequent acidity production shows a relationship between acidity and sulfate. This is expected, as these two parameters are mostly derived from the oxidation of pyrite within the mine. Demchak et al. (2001) found a linear relationship between sulfate and acidity with an $\mathrm{R}^{2}$ value of 0.67 . The first order decay equation was used to determine a decay rate for sulfate from 40 mines between 1968 and 2000. This sulfur decay rate was found to be $2.19 \%$. Through the use of regression analysis, values of both sulfate and acidity could be predicted over time. Studies by other researchers showed similar decline rates of acidity over time. Ziemkiewicz (1994) used a similar rate of $2 \%$ to determine acidity decreases in AMD discharges over time. Wood et al. (1999) determined a higher acidity decay rate of $3.34 \%$ as part of his study of mine discharges in Scotland. A rate of acidity decay greater than $2 \%$ could be found due to greater amounts of mineral precipitation or greater initial pyrite content. Although a large amount of research has been performed on the topic of water chemistry changes of AMD discharges over time, many of these studies do not have a large amount of historical data in order to draw comparisons. Concentrations of certain parameters may also be lacking in older data sets. Through the use of historical and current data, quantification of changes in discharge concentrations over time can be more accurately determined. Decay curves could provide an important prediction tool for future water quality of AMD discharges with suitable data. For example, Gzyl and Banks 
(2007) found that $\mathrm{pH}$ and sulfate decayed exponentially in two mines in Poland. They also found decay constants of -0.003 to -0.005 per day for sulfate. Decay curves could be extremely beneficial when a discharge is being considered for passive or active treatment. By being able to accurately estimate future acidity, metal, and sulfate concentrations, treatment systems can be designed to more efficiently neutralize AMD discharges.

\section{$\underline{\text { Objective }}$}

The objective of this study was to determine the changes in acidity, iron, aluminum, sulfate, and calcium concentrations over time in above-drainage underground mines using decay curves and percent decreases.

\section{Materials and Methods}

The Cheat River Watershed is located in Pocahontas, Randolph, Tucker, Preston, and Monongalia Counties of West Virginia, and Fayette County of Pennsylvania. It is contained within the Appalachian Plateau in the Allegheny Mountains (Fig 2-1). The geology of the Cheat River Basin includes systems from the Pennsylvanian, Mississippian, and Devonian ages. The rocks include: silt and clay shales, limestones, fire clays, massive sandstones, and coal. The coal beds are mostly from the Pennsylvanian age.

The two coal seams that are most prevalent in the Cheat River Basin are the Upper Freeport (UF) and the Pittsburgh seams (Skousen et al., 2002). The UF coal is in the top stratum of the Allegheny Formation of the Pennsylvanian system (Fig. 2-2). This seam typically contains $<1.5 \%$ sulfur and $8-12 \%$ ash. The UF coal seam has multiple beds which are divided into a top and bottom coal. These beds are divided by an interlayer of shale. The coal beds and the shale interlayer average a total of $2 \mathrm{~m}$ in thickness (Ruppert and Rice, 2000). Strata above the UF coal seam contain massive sandstones and shales. Very little or no limestone is found within $50 \mathrm{~m}$ of the UF coal seam, thus offering very little acid neutralization potential.

The Pittsburgh coal seam is the lowest stratum of the Monongahela Group of the Pennsylvanian System (Fig. 2-3). The seam has a sulfur content of 1.5-2\%, and an ash content of 6\%. The Pittsburgh seam is similar to the Upper Freeport seam in that it has layers of coal separated by layers of black shale. A typical cross-section of the Pittsburgh coal seam contains a $1 \mathrm{~m}$ layer of high-quality coal, a $0.7 \mathrm{~m}$ layer of slate, and a $2 \mathrm{~m}$ layer of good-quality coal. The Pittsburgh coal along the Monongahela and Cheat Rivers is located close to the surface, and can be easily obtained with surface or shallow underground mining methods. Similar to the Upper 
Freeport coal seam, there are few to no alkaline materials to neutralize the acid-producing material associated with the Pittsburgh coal seam in Monongalia county (Ruppert and Rice, 2000).

Forty abandoned mine drainage sites were selected for water sampling in the summer of 2005. These sites were selected because historic data were associated with them. Water sampling performed in 1968, 1980, and 2000 on these sites provided the baseline data to be used in this study. The number of samples taken in each sampling year is listed in Table 2-1. The sites were located in Preston and Monongalia counties in WV. The site locations were identified by using a Magellan Sportrak handheld GPS unit. The time since closure of each mine was determined using dates listed in the 1968 water sampling report (Demchak et al., 2004). All sites discharge water from abandoned above-drainage underground mines. All mines removed coal from either the Pittsburgh or UF coal seams.

\section{Sampling}

A previous research project was conducted during June-September of 1968-1970 to take water samples for all mine discharges in the Monongahela River basin. In the Cheat River subbasin from Parsons, WV to Pt. Marion, PA, 555 AMD sources were found, with 315 of these being underground mines (US Environmental Protection Agency, 1971). Maps and field sheets were completed for each site. Flow rates were measured with a bucket and stopwatch, or for larger flows, with installed V-notch weirs. Two water samples were taken at each discharge in this study: (I) a 1-L bottle was filled with water, put on ice, and then analyzed in the laboratory for acidity, alkalinity, conductivity, sulfate, and $\mathrm{pH}$; and (II) a 50-mL glass bottle was filtered and filled with water, treated with acid, and then analyzed in the laboratory for metals (total $\mathrm{Fe}, \mathrm{Mn}, \mathrm{Al}$ ). Water samples were delivered to the laboratory each Friday where they were analyzed using methodology from the latest edition of Standard Methods (American Public Health Association, 1965). Water analyses were monitored for accuracy and precision by periodically running reference standards.

Because only one sample was taken at each site during late summer and early fall in the 1968 study, the amount of error within a site could not be ascertained. However, the researchers and laboratory used standard sampling and analysis protocols to assure quality control of water quality results (American Public Health Association, 1965). This included the use of reference samples and duplicate analyses on each sample. 


\section{0 sampling}

The West Virginia Division of Water Resources also conducted periodic water sampling and analyses of underground mine discharges in this area (West Virginia Division of Natural Resources, 1985). We accessed their data and found that 20 of their mine sites matched our discharges sampled in 1968 and 1999-2000. Therefore, we used their water quality analyses as an intermediate data point between 1968 and 2000 to aid in estimating the rate of change (improvement) in water quality. Samples and flow measurements were taken during spring and summer 1980.

\section{Sampling}

Using maps and field sheets from the 1968 study, 40 underground mine discharge sites from the original group of 555 found in 1968 were located in 2000. Where water flowed out of the ground at each site, flow was determined by placing a pipe to capture the water and measuring the flow with a bucket and stopwatch. Two water samples were taken at each sample point: (I) a 250$\mathrm{mL}$ unfiltered sample was taken for general water chemistry $\mathrm{pH}$, total acidity and alkalinity by titration, and sulfate); and (II) a $25-\mathrm{mL}$ sample filtered with a 0.45 micrometer Nalgene syringe filter was acidified to $\mathrm{pH}$ of $<2$ with $0.5 \mathrm{~mL}$ concentrated nitric acid and used to determine metal concentrations. Flow and water samples were taken in spring and summer 2000.

Water $\mathrm{pH}$, acidity and alkalinity were determined by a Metrohm $\mathrm{pH}$ Stat Titrino System (Brinkman Instruments, Westbury, NY). Metal analysis was performed using a Plasma 400 inductively coupled spectrophotometer (PerkinElmer, Wellesley, MA). Sulfate was measured turbidimetrically by flow injection analysis (Latchat Instruments, Milwaukee, WI). Analyses were performed at West Virginia University's National Research Center for Coal and Energy analytical laboratory.

\section{6 sampling}

Water sampling was performed in the summer of 2006 in order to remain consistent with other sampling years.. Two sites (Cheat 4 and Fickey 3 ) were not included in the final analysis because they were dry during 2006.

Flows were measured by stretching a measuring tape across the width of the discharge and dividing the stream into sections. Each section was between 10 to $20 \%$ of the overall width of the discharge, so there were at least 5 measurement points for each discharge. Depth at each sampling point was measured using the 0.6 depth method (Buchanan and Somers, 1976). Velocity at each 
sampling point was found using a Marsh-McBirney Flo-Mate 2000 (Marsh-McBirney, Frederick, MD). The width interval, depth, and velocity were multiplied together at each point in order to determine flow. Total flow for the discharge was found by adding the flow values from each sampling section together. For discharges where the use of a flow meter was not practical, flows were determined by the bucket and stopwatch method. A bucket pre-marked at $2 \mathrm{~L}$ was filled with water. The amount of time needed to fill the bucket to the $2 \mathrm{~L}$ mark was recorded. This procedure was performed three times for each discharge and the values were averaged together to get the final flow value. The water sample collection procedure was the same as the 2000 study.

Water $\mathrm{pH}$ was determined by a Milwaukee Sharp $\mathrm{pH}$ meter (Milwaukee Meters, Southport, Australia) in the field and an Accumet Model $15 \mathrm{pH}$ meter (Fisher Scientific, Hampton, NH) in the laboratory. Conductivity was measured by a Milwaukee Sharp EC meter (Milwaukee Meters, Southport, Australia) in the field and a WTW LF 3000 (WTW, Weilheim, Germany) in the laboratory. Field measurements were used in the final analysis. Alkalinity (negligible for all sites) was determined by a digital titrator in the lab from a HACH model AL-DT kit (HACH Company, Loveland, CO). Acidity was determined using the same digital titrator as alkalinity, as well as by using the mathematical equation for calculated acidity based on $\mathrm{Fe}, \mathrm{Al}, \mathrm{Mn}$, and $\mathrm{pH}$ values (Kirby and Cravotta, 2004). Calculated acidity values were used in the final analysis. Metal concentrations were determined using an Inductively Coupled Spectrophotometer, Plasma 400 (Perkin Elmer, Norwalk, CT). Sulfate was determined turbidimetrically by flow injection analysis (Latchat Instruments, Milwaukee, WI).

\section{Data Analysis}

For all parameters, the concentration value from the 1968 water sampling was used as concentration at time $0\left(\mathrm{C}_{0}\right)$. Concentration $\mathrm{C}$ at each water sampling time $(1968,1980,2000$, and 2006) was divided by $\mathrm{C}_{0}$ in order to determine how the concentrations of each parameter changed over time. The natural $\log$ of $\mathrm{C} / \mathrm{C}_{0}$ was taken in order to determine the decay rate constant $(k)$ for each parameter. Each point on the $\mathrm{C} / \mathrm{C}_{0}$ vs. time since closure graphs represent relative concentrations over time for the 1968, 1980, 2000, and 2006 water sampling times. The relative concentration for each parameter was plotted against time since mine closure in two different ways. The first way was to group the values by decade that the mine was closed in, regardless of coal seam mined. The second way was to arrange the values to compare the Pittsburgh coal seam against the Upper Freeport coal seam, regardless of decade of closure.

Differences between $k$ values, concentrations, and percent differences for decade of closure and coal seam mined were deemed significant using Analysis of Variance (ANOVA). An alpha 
value of 0.1 was used to determine significance. All negative percent values were referred to as "percent change" and all positive percent values were referred to as "percent difference" to avoid confusion. A summary of calculated $k$ values from this research, along with $\mathrm{k}$ values from other studies, were tabulated in Appendix A.

Further analysis was performed on acidity concentrations for further determination of acidity changes over time. Acidity was chosen for further analysis because it was deemed the most important water quality indicator of all sampled parameters. Each of the 40 sites was plotted on a graph of acidity concentrations vs. sampling date to show changes in acidity over time. Due to the large amount of Upper Freeport sites, these sites were divided into four groups: sites with a 1968 acidity value of $>1600 \mathrm{mg} / \mathrm{L}$ as $\mathrm{CaCO}_{3}$ (12 sites), sites with 1968 acidities of 600-1599 mg/L (10 sites), sites with 1968 acidities of 0-599 (11 sites), and sites that had increased acidity over the 38year sampling period (one site).

A graph of decay curves representing various yearly acidity decline values from other research of $2 \%$, as well as comparison curves of 5 and $10 \%$, was constructed to compare to the mean acidity values of the 34 Upper Freeport and six Pittsburgh sites. Those Upper Freeport sites with four water sample points were also separated from those Upper Freeport sites with three water sample points. A relationship was established between $k$ values and time since closure using regression analysis in order to determine the effect of sampling frequency on acidity decay rates.

Acidity values from the T\&T \#2 mine in northern West Virginia (closed in 1996) were compared to the water sample values of five intensively sampled sites. The T\&T mine was chosen as a comparison because there is a large amount of water quality data associated with it. Acidity measurements have been taken at this mine monthly since 1996. A linear trend line was drawn through the acidity data from the T\&T \#2 mine, as well as the acidity data of the five intensively sampled sites. The slopes were compared to determine significant differences in the data graphs for each site. A test of parallelism was used to determine significance.

T\&T's acidity concentrations were also compared to the 2007 water sampling of the five sites to determine if decay rates are similar at specific times of the year. ANOVA was performed to determine if there were significant differences between mean acidity concentrations from the T\&T mine (water samples taken in March, May, and July of 1996-2007) and mean acidity concentrations from the five intensively sampled sites (water samples taken in March, May, and July 2007). 


\section{$\underline{\text { Results and Discussion }}$}

ANOVA was used to show significant differences for each parameter. Table 2-2 shows the results of the ANOVA for each parameter by both coal seam and decade of mine closure.

\section{Acidity changes by coal seam}

All Pittsburgh sites decreased in acidity from 1968-2006 (Fig. 2-4). The overall acidity change was $-74 \%$ for all sites for this time period (Table 2-3). The largest percent change (-83\%) for any range of years between samples was observed when comparing the 1968 acidities to the 1980 acidity values. This is the case for two reasons. The first reason is that underground mines from the Pittsburgh coal seam more quickly lose acidity due to the large amount of shales that make up the surrounding geology (Capo et al., 2001). Mack and Skousen (2007) found that four Pittsburgh mines also lost acidity faster over a longer period of time. The four Pittsburgh mines had an average annual acidity decline of $2.4 \%$, while Upper Freeport seam mines had an average acidity decline of $1.6 \%$ (Mack and Skousen, 2007).

The second reason is that the Pittsburgh mines had been closed for an average time of 31 years in 1968. It is assumed that the initial acidity value when the mine was closed was much higher than the one measured in 1968. Since there is no way of knowing what type of changes may have occurred within the mine environment in the first 31 years after mine closure, the decay rate may have been larger if we were able to compare the initial acidity at mine closure to the 1968 acidity value.

The Pittsburgh mines also lost a larger total percentage of their acidity between sampling times than the Upper Freeport mines (Table 2-3). Between 1968-1980 and 1980-2000, the acidity concentrations of the Pittsburgh mines decreased more quickly than the Upper Freeport mines. However, the Pittsburgh mines and the two groups of UF mines with the highest initial acidities showed increased acidity concentrations from 2000-2006, while the other two UF mine groups decreased during this time. The reasons for these increases between 2000 and 2006 are not known. Changes within these mines, such as exposure of fresh pyrite from roof/wall collapses or flushing of acidity from the mine with higher rainfall, could explain increased acidity concentrations in this time period. Amount of rainfall, amount of interconnected workings, initial metal concentrations, and initial amount of pyrite available for oxidation were found to affect acidity concentrations over time (Younger, 1997).

For Upper Freeport sites, Figs. 2-5, 2-6, 2-7, and 2-8 show the changes in acidity over time for each group of sites. The largest \% change was seen from 1968-1980 (Table 2-3) and the three 
Upper Freeport groups were similar in percent change at 1968-1980 and 1980-2000 sampling points.

There was one Upper Freeport site that had increased acidity concentrations for the time period from 1968-2006 (Fig. 2-8). This site had a low 1968 acidity value (250 mg/L), and showed a 46\% increase from 1968-2006 (Table 2-3). Acidity increased at each sampling point from 1968 to 2000 . However, acidity changed by $-31 \%$ from $2000-2006$. More water samples should be taken to see if this decreasing trend continues. The mine environment may still be in a state of flux, which could cause the observed vacillations in acidity concentrations.

The Pittsburgh mines had an overall mean acidity concentration $(992 \mathrm{mg} / \mathrm{L})$ that was $50 \%$ larger than the UF mines $(656 \mathrm{mg} / \mathrm{L})$ (Table 2-4). The Pittsburgh mines and UF mines showed no difference in percent change (-74\% vs. $-77 \%$ ) (Table $2-5)$. There was also no difference between acidity decay values ( $k$ values of -0.050 vs. -0.044) (Table 2-6). Ruppert and Rice (2000) stated that differences in coal seam properties could affect water chemistry. However, other factors could be controlling acidity changes over time, since neither the percent change in acidity nor the decay rate between coal seams was significantly different.

In addition to coal seam, the mines were grouped by the decade the mine was closed in. The mines closed in the $1940 \mathrm{~s}$ had lower mean acidity concentrations (600 mg/L) compared to mines closed in the 1930s (971 mg/L) and 1950s (719 mg/L) (Table 2-4). The mines closed in the 1930s and 1940s had a slightly greater percent change in acidity (-77\% and $-78 \%)$ than the mines closed in the 1950s (-71\%) (Table 2-5). However, the differences in percent change of acidity were not significant. This result was unexpected, since the mines closed in the 1930 s had more time to flush acidic reaction products from the mine and therefore we expected lower mean acidity concentrations and lower percent change than mines closed later. This is supported by previous research stating that time since mine closure may not have an impact on acidity concentrations after the mine has been closed for several decades (Wood et al., 1999; Jones et al., 1994). The mines closed in the $1940 \mathrm{~s}$ also had the fastest decrease $(k=-0.06)$ compared to -0.051 for mines closed in the 1930 s and -0.042 for mines closed in the 1950 s (Table 2-6). Values of $k$ were not significantly different between any of the decades of closure (Table 2-6). Relative acidity concentrations decreased over time exponentially, regardless of coal seam mined (Fig. 2-9) or decade of mine closure (Fig. 2-10).

\section{Acidity decay curves}

Twenty-one (17 UF and four Pittsburgh) of the 40 sites (34 UF and six Pittsburgh) were sampled four times $(1968,1980,2000$, and 2006), while the other sites were only sampled three 
times $(1968,2000$, and 2006). The number and spacing over time of water sample points may affect the shape of the acidity decay curve. Acidity concentrations typically decrease in an exponential fashion, although some mines have more linear trends. An example of a site that resembles each type of curve (Bull 2 is linear and Lynn 3 is exponential) can be seen in Fig. 2-11.

The means of the six Pittsburgh and 34 Upper Freeport sites were compared to three different ideal decay rates: $2 \%, 5 \%$, and $10 \%$. The 40 sites were also separated by the number of water samples taken (3 or 4) (Table 2-7) and compared to the three ideal decay rates (Fig. 2-12). The $2 \%$ curve was used due to its similarity to research done by Demchak et al. (2001) and Ziemkiewicz (1994). The 5\% and 10\% decay curves were used as comparisons.

The exponential trend line that extended through the six Pittsburgh sites had a slope value of -0.044 , which was more similar to the $5 \%$ decay rate curve (Fig. 2-13). Although the slopes of the decay curve for the six sites and the 5\% decay curve are similar, the mean acidity of the six sites decreased more quickly than the 5\% decay curve, which was especially true between 1968 and 1980. Since a mine's environment is constantly changing, especially right after mine closure, it is very unlikely that acidity concentrations will exactly mimic an ideal decay rate. The time between mine closure and the first sample taken could be very important for chemistry changes within the mine. Pyrite oxidation rate, reactable pyrite surface area, and mine geochemistry could change rapidly once the mine is closed due to a lack of new pyrite exposure from further mining. There is no way to quantify these changes unless the mine is sampled as soon as it is closed. Sample size may also make a difference in how closely the data approximates an ideal decay. Only four of the six mines had samples taken in 1980, which makes the 1980 mean less representative of the entire data set. However, as time since closure increased, all other acidity concentrations were closest to the $5 \%$ decay curve.

The mean acidity concentrations of the 34 sites showed a similar exponential decrease as the Pittsburgh sites (Fig. 2-14). The slope of the exponential trend line for the 34 sites was -0.050 , meaning that the curve that was the best fit was the 5\% decay curve (Fig. 2-14). Only an average of 19 years passed for the Upper Freeport mines, while 31 years elapsed for the Pittsburgh sites. The shorter amount of elapsed time for the Upper Freeport sites would leave less time for unknown effects on acidity within the mine environment. The acidity values of the $5 \%$ decay curve are likely more accurate to the Upper Freeport data because the first water sample was taken closer to the mine closure date than it was for the Pittsburgh sites.

Decay rate $(k)$ values for each site were graphed against time since closure to determine if sampling frequency affected changes in acidity concentrations. Neither group of sites had high correlation between $k$ values and time since closure $\left(\mathrm{R}^{2}=0.11\right.$ for four samples and 0.03 for three 
samples) (Figs. 2-15 and 2-16). These low $\mathrm{R}^{2}$ values mean there is not a good relationship between $k$ and time since mine closure. The wide spread (randomness) of the $k$ values shows that time since mine closure does not significantly affect decay rates of acidity.

The T\&T \#2 mine in Preston County, West Virginia was also compared to the four different decay rate curves mentioned in the previous section. This comparison was made in order to see the rate of acidity decay within the first 15 years after mine closure. The T\&T mine should still be in its "first flush" phase, which means that acidity concentrations should still be changing rapidly (Younger, 1997). A faster decay rate may result due to this shorter time since mine closure.

The relative concentration from 1996 was used as the relative concentration at the time of mine closure $\left(\mathrm{C} / \mathrm{C}_{0}=1\right)$. For comparison, the ideal decay rates of 2,5 , and $10 \%$ were also started at this relative concentration. The trendline closely matched the $10 \%$ decay curve with a slope of 0.104 (Fig. 2-17). This large decrease in acidity soon after closure is likely a result of the first flushing of the water within the mine (Younger, 1997). After mining is completed, fewer disturbances occur inside the mine and acidity from the mine begins to decline after the first major flush. With time, the mine environment continues to lose acidity due to lessened amounts of pyrite oxidation and increased flushing. However, over time, the acidity loss occurs more slowly than in the initial time periods after mine closure (Younger, 1997; Wood et al., 1999). Further water sampling in the future could show that the decay rate for T\&T also slows and is similar to other mines we measured as time progresses. It is also likely that this result could be extrapolated to other coal seams with similar chemistry that were mined above the local water table.

\section{Seasonal changes in acidity}

Acidity data from the T\&T \#2 mine was also compared to acidity concentrations of five intensively sampled mine sites. This was done to determine the effects of sampling season on acidity. Water samples from March, May, and July 2007 (five sites) and March, May, and July 1996-2007 (T\&T) were evaluated to see if acidity trends were similar regardless of the year in which they were taken.

Acidity from each of the five sites was graphed against the acidity data for T\&T (Fig. 218). All sites showed an increase in acidity from March to July (Table 2-9). Distinct groups of sites were observed based on slopes of trend lines (Table 2-8), even though acidity values were different from site to site. Fickey 6, T\&T, and Muddy 11 were one group (slope of 20 to 30), Fickey 5 and Fickey 7 were a second group (slope between 90 and 100), and Greens 3 (slope of 215) was a third group (Table 2-8). 
ANOVA was used to determine if acidity concentrations were significantly different from one another for each sampling month. Mean acidity concentrations were found to be significantly different in March, but not in May or July (Table 2-9). T\&T acidity across these three months during the past 12 years has been relatively constant $(648 \mathrm{mg} / \mathrm{L}$ to $708 \mathrm{mg} / \mathrm{L})$ compared to the average acidity of several sites during only one year $(342 \mathrm{mg} / \mathrm{L}$ to $524 \mathrm{mg} / \mathrm{L})$. A larger difference in acidity values was expected in March due to increased rainfall and snowmelt. This pattern could be further quantified if these same discharges were sampled for several more years.

Given the small number of sample points for the five intensively sampled sites, it is possible that these changes in acidity could be due to storm events instead of seasonal changes. If the water sample is taken too close to the conclusion of a storm event, the amount of acidity will likely be different than if the sample is taken during a dry period. Because of this issue, it is very difficult to separate acidity values due to storm events from acidity due to seasonal changes in precipitation. The T\&T mine should be less subject to this problem because acidity values were taken more often, which would allow for better correlation between acidity concentrations and flow.

$\mathrm{Fe}$

There were no significant differences in Fe concentrations among decades of closure (100$167 \mathrm{mg} / \mathrm{L} \mathrm{Fe}$ ) (Table 2-4), nor were there differences in percent change (Table 2-5). Differences between $k$ values for decades of closure were not significant for Fe (Table 2-6). Overall, iron concentrations decreased over time in an exponential manner (Fig. 2-19 and 2-20).

Fe concentrations decrease over time for many of the same reasons as acidity concentrations. Any factor that slows the speed of pyrite dissolution will affect the concentration of Fe in the discharge. In addition to those factors that affect acidity, pool formation can create anoxic environments by forcing out the oxygen in part of the mine. Parts of the mine also may collapse, sealing off further pyrite reaction due to a lack of water and/or oxygen.

Fe concentrations between coal seams were not significant, even though the mines from the Pittsburgh coal seam had a higher initial mean Fe concentration (157 vs. $102 \mathrm{mg} / \mathrm{L} \mathrm{Fe}$ ) (Table 2-4). The percent change of the two coal seams also was not significantly different (-76\% vs. $-82 \%$ ) (Table 2-5). Fe concentration $k$ values were also not significantly different between coal seams (-0.060 vs. -0.070) (Table 2-6 and Fig. 2-20).

Fe decay rates from other research are smaller than those found here. Koryak et al. (2004) found that Fe concentrations decreased 2\%/yr over the course of 48 years in several streams of the Allegheny River watershed, although a direct comparison between Fe decline rates in streams and mines is difficult. McDonough et al. (2005) determined a 1.8\%/yr. decay rate from a large sample 
of mines throughout the Appalachian coal region. However, McDonough was studying mines from many different coal seams and mining regions, which may have contributed to the different decay rate he found.

Other factors likely have an impact on Fe concentrations over time since neither different decades of mine closure or coal seam mined were significantly different. Mine flooding causes iron concentrations to decrease over time (Lambert and Dzombak, 2000; Vermeulen and Usher, 2006). However, all mines in this research were above-drainage and not flooded. A likely reason for changes in Fe concentrations over time is a change in the amount of water or oxygen within the mine, which in turn will slow the reaction rate of the pyrite within the mine. Factors such as reclamation practices or soil compaction could affect the rate of pyrite oxidation (Borek et al, 1999; (Demchak et al., 2004).

\section{Al}

The mines closed in the 1940s had a significantly lower Al concentration of $36 \mathrm{mg} / \mathrm{L}$ than mines closed in the 1930s or 1950s (Table 2-4). However, Al had the greatest percent change from mines closed in the 1930s (-82\%) (Table 2-5). None of the differences in percent change were significant (Table 2-5), although the p value of 0.13 was nearly significant between the $1930 \mathrm{~s}$ and 1940s. Values of $k$ for Al decay were greatest for mines that were closed in the 1930s $(k=-0.056)$, followed by mines closed in the 1940s and 1950s (-0.050 and -0.028) (Fig. 2-21 and Table 2-6). The $k$ values of Al decay were not significant between decades of closure (Table 2-6).

Mean Al concentrations were significantly different between coal seams with the Pittsburgh mines having a mean $\mathrm{Al}$ concentration roughly 2 times higher than the UF mines (33 vs. $83 \mathrm{mg} / \mathrm{L}$ ) (Table 2-4). The percent change in Al concentrations was not significant between coal seams (Table 2-5). Decay rates of Al between coal seams were not significantly different (Table 26 and Fig. 2-22).

It was assumed there would be more significant differences between coal seams because of differences in geology and minerals of the two coal seams. The $\mathrm{pH}$ values of all sites were less than 4.5, which is the $\mathrm{pH}$ at which $\mathrm{Al}$ becomes insoluble (Nordstrom and Ball, 1986). Other factors could be controlling the decline rates of $\mathrm{Al}$, such as initial amounts of $\mathrm{Al}$ minerals present in the mines.

\section{$\mathrm{SO}_{4}$}

There were no significant differences between decades of closure for $\mathrm{SO}_{4}$ (Table 2-4). We expected to find significant differences between the mines closed first and those that were closed 
later because these mines had more time to react greater amounts of pyrite and more time to flush the $\mathrm{SO}_{4}$. As time passed, there should have been less pyrite available for oxidation, which in turn would decrease the amount of $\mathrm{SO}_{4}$ in the AMD solution.

There were no significant differences between decades of closure (Table 2-5). Values of $k$ for sulfate were not significantly different among mine closure decades (Table 2-6 and Fig. 2-23). The mines closed in the 1940s had the largest $k$ value of -0.045 (fastest decrease), followed by the $1930 \mathrm{~s}$ and the 1950s (with -0.032 to -0.030) (Table 2-6).

There was a significant difference between the mean concentrations of $\mathrm{SO}_{4}$ when comparing coal seams (1126 vs. $1908 \mathrm{mg} / \mathrm{L}$ ) (Table 2-4). Mines in the Pittsburgh seam also had a $-68 \%$ change over time, as opposed to the $-65 \%$ change of the mines in the UF seam (Table 2-5). Values of $k$ of $\mathrm{SO}_{4}$ in the Pittsburgh mines did not decrease significantly faster than those in the UF mines (-0.039 vs. -0.036$)$ (Table 2-6 and Fig. 2-24).

The decay rate of roughly $2.8 \% / y r$. found in this research is slightly higher than the decay rates of 2 and 2.19\% found by Demchak et al. (2001) and Ziemkiewicz (1994) and lower than the rate found by Wood et al. (1999) of 3.3.4\%. However, the mean decay rate among these three researchers was $2.5 \%$, which compares favorably to that found in this thesis. These results suggest that $\mathrm{SO}_{4}$ concentrations decline at a similar rate independent of factors such as coal seam mined or time since mine closure.

\section{Ca}

Ca concentrations may have differed from all other parameters due to fewer water samples taken for this parameter than any of the others. Ca was not sampled during the 1980 sampling date, which gave a sampling frequency of three instead of four. Due to this smaller sample size, analysis of $\mathrm{Ca}$ concentrations was not as precise as the other sampled parameters, which were sampled in 1968, 1980, 2000, and 2006.

None of the differences in Ca concentrations between decades of closure were significant (Table 2-4). If Ca were considered a time-dependent element, than we would expect to see the highest concentrations in mines closed in the 1950s, but this was not the case. Mines closed in the $1930 \mathrm{~s}$ and 1940s had significantly greater mean percent changes in Ca concentrations than 1950s mines ( -68\% vs. $-42 \%$ ) (Table 2-5). Average values of $k$ for Ca differed from 1930s and 1940s mines (-0.038 and -0.039) compared to -0.018 for the 1950s mines (Table 2-6 and Fig. 2-25).

Mean Ca concentrations were nearly identical between the two coal seams (Table 2-4). The Pittsburgh mines had a larger mean percent change than the UF mines $(-70 \%$ vs. $-52 \%$ ) (Table 2-4), but surprisingly this difference was not significant. Values of $k$ appeared to decrease more quickly in the Pittsburgh mines (-0.036) than the UF mines (-0.027) (Table 2-6 and 
Fig. 2-26), but the mean $k$ values of the two coal seams were not significantly different from one another.

The 10-20 year difference in mine closure date in these groups of mines may be a critical time for $\mathrm{Ca}$ decreases. The geology surrounding the coal seams may undergo important changes within that time span, such as changes in water paths within the mine, which could bring more alkaline surface water into the mine void. The dissolution rate of clay and carbonate minerals may also change as time passes due to geochemical changes within the mine such as changes in $\mathrm{pH}$. The other possible sources of $\mathrm{Ca}$ in mine water, such as anhydrite from the mine walls or limestone dust used for fire suppression, will also likely have been consumed in the acidic environment of the mine over time (Mckee and Hannon, 1985; Banks et al., 1997).

\section{Conclusions}

The flow and chemistry of 40 mine sites were determined and grouped by coal seam (Pittsburgh or Upper Freeport). All six Pittsburgh sites had decreased acidity from the time period of 1968-2006. The average change over this time was $-74 \%$ and related to a $4 \%$ exponential decay. The largest decrease between sampling dates was from 1968-1980. This occurred because of the rapid release of acidity from the shales surrounding the Pittsburgh seam. It was also noted that the Pittsburgh sites were closed for an average of 31 years before the first sampling, which allowed for changes in water chemistry before the initial water sampling took place. The Pittsburgh mines also lost a greater percentage of acidity between sampling dates than did the Upper Freeport mines.

The 34 Upper Freeport mines also showed decreased acidity concentrations from 19682006 (average of $-76 \%$ ). Similar to the Pittsburgh sites, the largest acidity decrease occurred between 1968 and 1980. However, the percent change (both for 1968-1980 and all other sample year ranges) was smaller than the Pittsburgh sites. One UF site also had increased acidity from 1968-2006. More water sampling is needed to determine if this site will continue to increase, or if it will begin to behave like the rest of the sites.

Mean acidity concentrations of the six Pittsburgh and 34 Upper Freeport sites were graphed against decay curves of 2, 5, and 10\%. Slopes of the decay curves for the Pittsburgh and Upper Freeport data sets matched closest to the slope of the $5 \%$ decay curve. The point that was the most different from the ideal 5\% decrease was the sample taken in 1968. However, this sample point was closer to the ideal curve for the Upper Freeport data than for the Pittsburgh data.

The Upper Freeport sites were also divided into those sites that were sampled four times from 1968-2006 and those that were sampled three times within the same time period. No

relationship was found between sampling frequency and decay rates. 
The T\&T \#2 mine was also compared to the three ideal decay curves. Unlike the other groups of sites, T\&T most closely matched the $10 \%$ decay curve. However, T\&T has only been closed for 12 years. It is probable that the T\&T mine is declining quickly as salts built up in the mine are being flushed out initially after closure.

Acidity concentrations taken in March, May, and July from both T\&T and five other sites were compared to determine seasonal effects on acidity. All sites showed an increase in acidity over this time period. The mean acidity concentrations of the five sites were $37 \%$ less than those of T\&T. However, acidity increased more quickly in the five sites. Acidity values in March were significantly different between T\&T and the 5 sites, but not in May or July. More water sampling would determine if this trend is correct.

Four other parameters were chosen to assess how water quality of the 40 sites changed over time. These parameters were related to decade of mine closure and coal seam mined. Concentrations of all sampled parameters $\left(\mathrm{Fe}, \mathrm{Al}, \mathrm{SO}_{4}\right.$, and $\left.\mathrm{Ca}\right)$ for all 40 sites decreased exponentially over time between 1968 and 2006. Concentrations of sampled parameters showed various degrees of significance with either decade of mine closure or coal seam. Across all sites, acidity decreased by $75 \%$, Fe by $81 \%$, Al by $64 \%, \mathrm{SO}_{4}$ by $65 \%$, and Ca by $54 \%$. Values for $k$ of measured parameters (representing exponential decay rates) varied between -0.018 to -0.070 .

\section{$\underline{\text { Literature Cited }}$}

Akcil, A. and Koldas, S. 2006. Acid Mine Drainage (AMD): Causes, treatment, and case studies. Journal of Cleaner Production 14 (12-13): 1139-1145.

American Public Health Association. 1965. Standard Methods for the Examination of Water and Wastewater. $10^{\text {th }}$ Edition. APHA, Washington, DC.

Banks, D., Younger, P.L., Arnesen, R.-T., Iversen, E.R., and Banks, S.B. 1997. Mine-water chemistry: The good, the bad, and the ugly. Environmental Geology 32 (3): 157-174.

Bennett, L. 1991. Abandoned mines: report from WV. EPA Journal 17 (5): 16-18.

Borek S. L., Ackman, T.E., Watzlaf, G. P., Hammack, R.W., and Lipscomb, J.P. 1991. The longterm evaluation of mine seals constructed in Randolph County, WV in 1967. In Proceedings of the $12^{\text {th }}$ Annual West Virginia Surface Mine Drainage Task Force

Symposium, April 3-4, 1991, Morgantown, W.V.

Brady, K.B., Hornberger, R.J., and Fleeger, G. 1998. Influence of geology on post-mining water quality: northern Appalachian Basin. pp. 8-1 to 8-92 In Coal Mine Drainage Prediction and Pollution Prevention in Pennsylvania. PA Department of Environmental Protection. Harrisburg, PA. 
Buchanan, T.J. and Somers, W. P. 1976. Discharge measurements at gauging stations. Chap. A8, p. 32-33 In Techniques of Water-Resources Investigations of the United States Geological Survey, Book 3; Application of Hydraulics. USGS, Washington D.C.

Capo, R.C., Winters, W.R., Weaver, T.J., Stafford, S.L., Hedin, R.S., and Stewart, B.W. 2001. Hydrologic and geochemical evolution of deep mine discharges, Irwin Syncline, Pennsylvania. $\mathrm{p}$ 1-10. In $22^{\text {nd }}$ Annual West Virginia Surface Mine Drainage Task Force Symposium. Morgantown, WV. 3 April-4 April, 2001.

Demchak, J, Skousen, J., and McDonald, L.M. 2004. Longevity of acid discharges from underground mines located above the regional water table. Journal of Environmental Quality 33: 656-658.

Demchak, J., Skousen, J., and McDonald, L. 2001. Water Quality Improvements Over Time and Longevity of Acid Mine Discharges From Underground Mines in Northern West Virginia. In $18^{\text {th }}$ Annual National Meeting of the American Society of Mining and Reclamation. Albuquerque, NM. 3 June-7 June, 2001.

Gzyl, G. and Banks, D. 2007. Verification of the "first flush" phenomenon in mine water from coal mines in the Upper Silesian Coal Basin, Poland. Journal of Contaminant Hydrology 92 (1-2): 6686.

Horan, J. 1999. Thiobacillus ferrooxidans. www.mines.edu/fs_home/jhoran/ch126/thiobaci.htm. Accessed 8/16/06. Updated 12/3/99.

Jones, P.M., Mulvay, S.M., and Fish, D. 1994. The role of sulfate and ionic strength on the shift from acid to alkaline mine drainage in southwest Pennsylvania. pp. 289-295 In Proceedings of the International Land Reclamation and Mine Drainage Conference and the Third International Conference of the Abatement of Acid Mine Drainage. Vol. 2: Mine Drainage. US Bureau of Mines Special Publication SP 06B-94.

Koryak, M., Stafford, L.J., and Reilly, R.J. 2004. Declining intensity of acid mine drainage in the northern Appalachian bituminous coal fields: Major Allegheny River tributaries. Journal of the American Water Resources Association (JAWRA) 40 (3):677-689.

Kirby, C.S., and Cravotta III, C.A. 2004. Net alkalinity and net acidity 1: Theoretical considerations. Applied Geochemistry 20: 1920-1940.

Lambert, D.C. and Dzombak, D.A. 2000. Evaluation of natural amelioration of acidic deep mine discharges in the Uniontown Syncline, Pennsylvania. In Proceedings of the $21^{\text {st }}$ West Virginia Surface Mine Drainage Task Force Symposium, April 4-5, 2000, Morgantown, WV. Mack, B. and Skousen, J. 2007. Changes in water quality of 34 above-drainage mines in West Virginia. In $24^{\text {th }}$ Annual National Meeting of the American Society of Mining and Reclamation, 30 Years of SMCRA and Beyond. Gillette, WY. 2 June- 7 June, 2007.

Martin, R. W. 2004. Watershed-scale thermal regimes and the distribution of brook trout (Salvelinus fontinalis) and smallmouth bass (Micropterus dolomieui) in the Cheat River watershed, WV. Masters thesis, West Virginia University, Morgantown, WV. 
McCulloch, C.M., Diamond, W.P., Bench, B.M., and Duel, M. 1975. Selected geologic factors affecting mining of the Pittsburgh coal bed. p. 12 In Bureau of Mines Report of Investigations 8093. Department of the Interior, Washington DC.

McDonough, K., Lambert, D.C., Mugunthan, P., and Dzombak, D.A. 2005. Hydrologic and geochemical factors governing chemical evolution of discharges from an abandoned, flooded underground coal mine network. Journal of Environmental Engineering 131 (10): 643-650.

McKee, D. M. and Hannon, P.J. 1985. The hydrological environment of the Gays River mine. International Journal of Mine Water 4 (2): 13-34.

Nordstrom, D., and Ball, J. 1986. The geochemical behavior of aluminum in acidified surface waters. Science, New Series 232 (4746): 54-56.

Rose, A. W., and Cravotta, C. A. III. 1998. Chapter 1:Geochemistry of coal mine drainage In Coal Mine Drainage Prediction and Pollution Prevention in Pennsylvania: 1-1 to 1-22. PA Department of Environmental Protection. Harrisburg, PA.

Ruppert, L.F., and Rice, C.L. 2000. Chapter B-Coal resource assessment methodology and geology of the northern and central Appalachian Basin coal regions. In Northern and Central Appalachian Basin Coal Regions Assessment Team, 2000 resource assessment of selected coal beds and zones in the northern and central Appalachian Basin coal regions: U.S. Geological Survey Professional Paper 1625-C. United States Geological Survey, Washington DC.

Skousen, J., Simmons, J., McDonald, L.M., and Ziemkiewicz, P. 2002. Acid-base accounting to predict post-mining drainage quality on surface mines. J. Environ. Qual. 31: 2034-2044.

Steidl, P.F. 1977. Geology and methane content of the Upper Freeport coalbed in Fayette County, PA. p. 4. In Bureau of Mines Report of Investigations 8226. Department of the Interior, Washington DC.

US Environmental Protection Agency. 1971. Summary report, Monongahela River mine drainage remedial project. p. 1-146. In: Proceedings in the matter of pollution of the interstate waters of the Monongahela River and its tributaries-Pennsylvania, West Virginia, and Maryland. Second session, Pittsburgh, PA. 24 August, 1971.

US Environmental Protection Agency. 2006. Mid-Atlantic integrated assessment of acid mine drainage. http://www.epa.gov/maia/html/AMD_issue.html. Accessed 8/15/06, Updated 3/3/06.

Vermeulen, P., and Usher, B.H. 2006. Sulphate generation in South African underground and open cast collieries. Environmental Geology 49(4): 552-569.

West Virginia Department of Natural Resources. 1985. Cheat River subbasin abandoned mine drainage assessment. WV DNR, Division of Water Resources. Charleston, WV.

West Virginia Office of Miners Health, Safety, and Training. 2007. A Brief History of Coal and Safety Enforcement in West Virginia. http://www.wvminesafety.org/HISTORY.HTM. Updated 07/26/2007, Accessed 07/30/2007. 
Wood, S.C., Younger, P.L., and Robins, N.S. 1999. Long-term changes in the quality of polluted minewater discharges from abandoned underground coal workings in Scotland. Quarterly J. Engineering Geology 32: 69-79.

Younger, P. L. 1997. The longevity of minewater pollution: a basis for decision-making. The Science of the Total Environment 194-195: 457-466.

Ziemkiewicz, P. 1994. A simple spreadsheet for predicting acid mine drainage. In International Land Reclamation and Mine Drainage Conference, USDI, Bureau of Mines SP 06A-94. Pittsburgh, PA. 
Table 2-1. Number of samples taken at each site in each sampling year.

\begin{tabular}{cc}
\hline $\begin{array}{l}\text { Sampling } \\
\text { year }\end{array}$ & $\begin{array}{l}\text { Number of } \\
\text { samples }\end{array}$ \\
\hline 1968 & 1 \\
1980 & 1 \\
2000 & 1 \\
2006 & 1 \\
\hline
\end{tabular}

Table 2-2. ANOVA results for sampling dates, coal seam, and decade of closure. Interactions between dates and coal seams as well as dates and decades of closure are also shown. "Type III SS" is Type III Sum of Squares, which is used in the determination of the $F$ value. All $P$ values less than or equal to 0.10 are significantly different from the other class values for that class.

\begin{tabular}{|c|c|c|c|c|c|c|c|}
\hline Class & $\begin{array}{c}\text { Nested } \\
\text { Class } \\
\text { Values }\end{array}$ & Parameter & df & Type III SS & $F$ value & $P$ value & Sig? \\
\hline Sampling Dates & & Acidity & 1 & 83361325 & 44.68 & $3.12 \mathrm{E}-09$ & $\mathrm{Y}$ \\
\hline \multirow{4}{*}{ (1968 vs. 2006) } & & $\mathrm{Fe}$ & 1 & 2716040 & 38.23 & 2.69E-08 & $Y$ \\
\hline & & $\mathrm{Al}$ & 1 & 594883 & 20.30 & 2.29E-05 & $Y$ \\
\hline & & $\mathrm{SO} 4$ & 1 & $2.12 \mathrm{E}+08$ & 21.79 & $1.24 \mathrm{E}-05$ & $Y$ \\
\hline & & $\mathrm{Ca}$ & 1 & 2920817 & 28.47 & $9.04 \mathrm{E}-07$ & $Y$ \\
\hline Coal Seam & & Acidity & 1 & 99322008 & 2.80 & 0.10 & $Y$ \\
\hline \multirow[t]{4}{*}{ (UF vs. Pitts.) } & & $\mathrm{Fe}$ & 1 & 3191411 & 2.54 & 0.11 & $\mathrm{~N}$ \\
\hline & & $\mathrm{Al}$ & 1 & 462572 & 6.08 & 0.02 & Y \\
\hline & & $\mathrm{SO} 4$ & 1 & $2.43 E+08$ & 6.61 & 0.01 & $Y$ \\
\hline & & $\mathrm{Ca}$ & 1 & 3400270 & 0.17 & 0.68 & $\mathrm{~N}$ \\
\hline Closure decade & & Acidity & 2 & 99322008 & 1.30 & 0.28 & $\mathrm{~N}$ \\
\hline (1930s vs. 1940s vs. & & $\mathrm{Fe}$ & 2 & 3191411 & 1.48 & 0.23 & $\mathrm{~N}$ \\
\hline \multirow[t]{3}{*}{ 1950s) } & & $\mathrm{Al}$ & 2 & 714824 & 3.29 & 0.04 & $\mathrm{Y}$ \\
\hline & & $\mathrm{SO} 4$ & 2 & $2.43 E+08$ & 0.60 & 0.55 & $\mathrm{~N}$ \\
\hline & & $\mathrm{Ca}$ & 2 & 3400270 & 1.21 & 0.30 & $\mathrm{~N}$ \\
\hline
\end{tabular}

Table 2-3. Percent changes in acidity between sampling dates. UF=Upper Freeport coal seam.

\begin{tabular}{lccccc}
\hline \multicolumn{1}{c}{ Sites } & $\mathbf{n}$ & $\mathbf{1 9 6 8 - 1 9 8 0}$ & $\mathbf{1 9 8 0 - 2 0 0 0}$ & $\mathbf{2 0 0 0 - 2 0 0 6}$ & $\mathbf{1 9 6 8 - 2 0 0 6}$ \\
\hline Pittsburgh & 6 & $-83 \%$ & $-58 \%$ & $87 \%$ & $-74 \%$ \\
UF > 1600 & 12 & $-58 \%$ & $-44 \%$ & $10 \%$ & $-81 \%$ \\
UF 1599-600 & 10 & $-43 \%$ & $-35 \%$ & $5 \%$ & $-79 \%$ \\
UF < 600 & 11 & $-23 \%$ & $-4 \%$ & $-42 \%$ & $-70 \%$ \\
Increasing UF & 1 & $44 \%$ & $47 \%$ & $-31 \%$ & $46 \%$ \\
\hline
\end{tabular}


Table 2-4. Mean concentrations for three different data groupings. The letters next to the values represent significant differences between values. For example, "a" is significantly different from "b."

\begin{tabular}{|c|c|c|c|c|c|c|c|c|}
\hline Group & Group values & $n$ & $\mathrm{pH}$ & Acidity & $\mathrm{Fe}$ & $\mathrm{Al}$ & SO4 & $\mathrm{Ca}$ \\
\hline & & & & --- & ----- & $\mathrm{ng} / \mathrm{L}-$ & ------ & ----- \\
\hline Dates & $1968-2006$ & 141 & 3.0 & 708 & 111 & 52 & 1248 & 172 \\
\hline \multirow[t]{2}{*}{ Coal seam } & UF & 119 & $3.1 a$ & $656 b$ & $102 a$ & $33 b$ & $1126 \mathrm{~b}$ & $169 a$ \\
\hline & Pitts. & 22 & $2.8 a$ & $992 a$ & $157 a$ & $83 a$ & $1908 a$ & $188 a$ \\
\hline \multirow[t]{3}{*}{ Decade of closure } & 1930s & 18 & $3.3 a$ & $971 a$ & $167 a$ & $84 a$ & $1537 a$ & $177 a$ \\
\hline & 1940s & 50 & $3.1 a$ & $600 a$ & $100 a$ & $36 c$ & $1293 a$ & $203 a$ \\
\hline & $1950 \mathrm{~s}$ & 73 & $2.9 a$ & $719 a$ & $105 a$ & $54 b$ & $1145 a$ & $151 a$ \\
\hline
\end{tabular}

Table 2-5. Mean percent changes for three different data groupings. The letters next to the values represent significant differences between values. For example, " $a$ " is significantly different from " $b . "$

\begin{tabular}{cccccccc}
\hline Group & Group values & $\mathbf{n}$ & Acidity & Fe & Al & SO4 & Ca \\
\hline Dates & $1968-2006$ & 141 & $-75 \%$ & $-81 \%$ & $-64 \%$ & $-65 \%$ & $-54 \%$ \\
Coal seam & UF & 119 & $-77 \% a$ & $-82 \% a$ & $-61 \% a$ & $-65 \% a$ & $-52 \% a$ \\
& Pitts. & 22 & $-74 \% a$ & $-76 \% a$ & $-79 \% a$ & $-68 \% a$ & $-70 \% a$ \\
Decade of closure & & & & & & & \\
& $1930 \mathrm{~s}$ & 18 & $-77 \% \mathrm{a}$ & $-74 \% \mathrm{a}$ & $-82 \% \mathrm{a}$ & $-65 \% \mathrm{a}$ & $-69 \% \mathrm{a}$ \\
& $1940 \mathrm{~s}$ & 50 & $-78 \% \mathrm{a}$ & $-84 \% \mathrm{a}$ & $-55 \% \mathrm{a}$ & $-70 \% \mathrm{a}$ & $-67 \% \mathrm{a}$ \\
& $1950 \mathrm{~s}$ & 73 & $-71 \% \mathrm{a}$ & $-81 \% \mathrm{a}$ & $-65 \% \mathrm{a}$ & $-62 \% \mathrm{a}$ & $-42 \% \mathrm{~b}$ \\
\hline
\end{tabular}

Table 2-6. Mean $k$ values for three different data groupings. The $k$ value is equivalent to the slope of the data. The letters next to the values represent significant differences between values. For example, "a" is significantly different from "b."

\begin{tabular}{cccccccc}
\hline Group & Group values & $\mathbf{n}$ & Acidity & Fe & Al & SO4 & Ca \\
\hline Dates & $1968-2006$ & 141 & -0.050 & -0.068 & -0.039 & -0.036 & -0.028 \\
Coal Seam & UF & 119 & $-0.050 \mathrm{a}$ & $-0.070 \mathrm{a}$ & $-0.037 \mathrm{a}$ & $-0.036 \mathrm{a}$ & $-0.027 \mathrm{a}$ \\
& Pitts. & 22 & $-0.045 \mathrm{a}$ & $-0.060 \mathrm{a}$ & $-0.050 \mathrm{a}$ & $-0.039 \mathrm{a}$ & $-0.036 \mathrm{a}$ \\
& & & & & & & \\
Decade of & $1930 \mathrm{~s}$ & 18 & $-0.051 \mathrm{a}$ & $-0.073 \mathrm{a}$ & $-0.056 \mathrm{a}$ & $-0.032 \mathrm{a}$ & $-0.038 \mathrm{a}$ \\
closure & & & & & & & \\
& $1940 \mathrm{~s}$ & 50 & $-0.060 \mathrm{a}$ & $-0.079 \mathrm{a}$ & $-0.050 \mathrm{a}$ & $-0.045 \mathrm{a}$ & $-0.039 \mathrm{a}$ \\
& $1950 \mathrm{~s}$ & 73 & $-0.042 \mathrm{a}$ & $-0.060 \mathrm{a}$ & $-0.028 \mathrm{a}$ & $-0.030 \mathrm{a}$ & $-0.018 \mathrm{~b}$ \\
\hline
\end{tabular}


Table 2-7. Mean acidity concentrations for 4 different data groups. UF= Upper Freeport, UF X 4= Upper Freeport sites sampled four times, and UF X 3= Upper Freeport sites sampled three times.

\begin{tabular}{cccccc}
\hline Groups & $\mathbf{n}$ & $\mathbf{1 9 6 8}$ & $\mathbf{1 9 8 0}$ & $\mathbf{2 0 0 0}$ & $\mathbf{2 0 0 6}$ \\
\hline Pittsburgh & 6 & 2398 & 574 & 412 & 447 \\
UF & 34 & 1351 & 598 & 379 & 265 \\
UF X 4 & 17 & 1250 & 598 & 409 & 293 \\
UF X 3 & 17 & 1452 & NS & 349 & 291 \\
\hline
\end{tabular}

Table 2-8. Slope of linear trend lines for T\&T and the five other sites.

\begin{tabular}{cc}
\hline Site & Slope of trend line \\
\hline Green 3 & $215.4 \mathrm{a}$ \\
Fickey 7 & $99.5 \mathrm{~b}$ \\
Fickey 5 & $93.7 \mathrm{~b}$ \\
T\&T & $29.9 \mathrm{c}$ \\
Muddy 11 & $25.3 \mathrm{c}$ \\
Fickey 6 & $20.2 \mathrm{c}$ \\
\hline
\end{tabular}

Table 2-9. Mean acidity concentrations for $T \& T$ and 5 other sites. The percent difference between the means is shown for each sample month.

\begin{tabular}{ccccc}
\hline Site & March & May & July & Mean of all months \\
\hline T\&T & $648 a$ & $644 a$ & $708 a$ & $667 a$ \\
5 sites & $342 b$ & $400 a$ & $524 a$ & $422 b$ \\
Percent difference & $47 \%$ & $38 \%$ & $26 \%$ & $37 \%$ \\
\hline
\end{tabular}




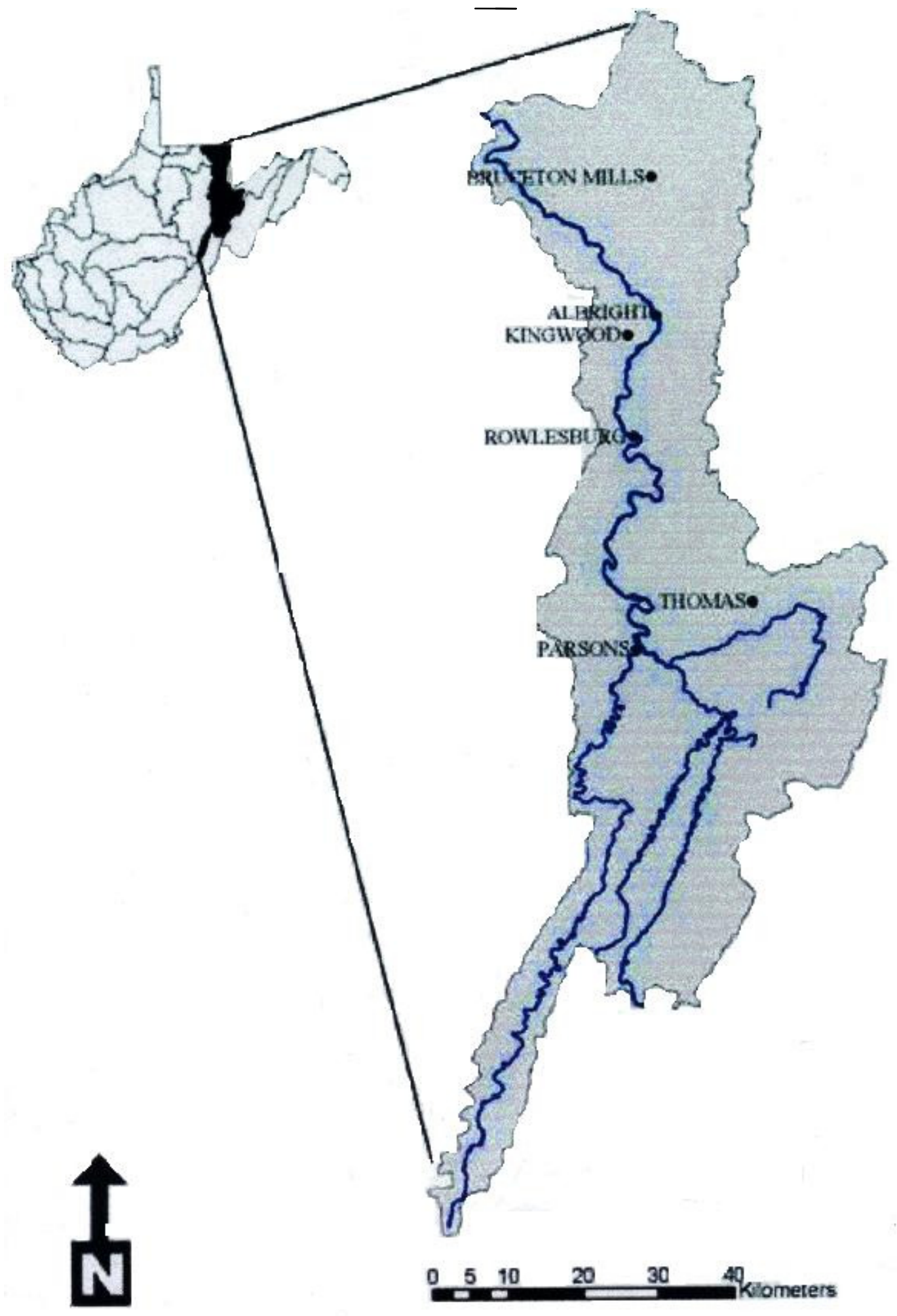

Fig. 2-1. Map of the Cheat River Watershed. Most AMD problems in the watershed are from Rowlesburg north to the river's terminus with the Monongahela River (Figure from Martin, 2004). 


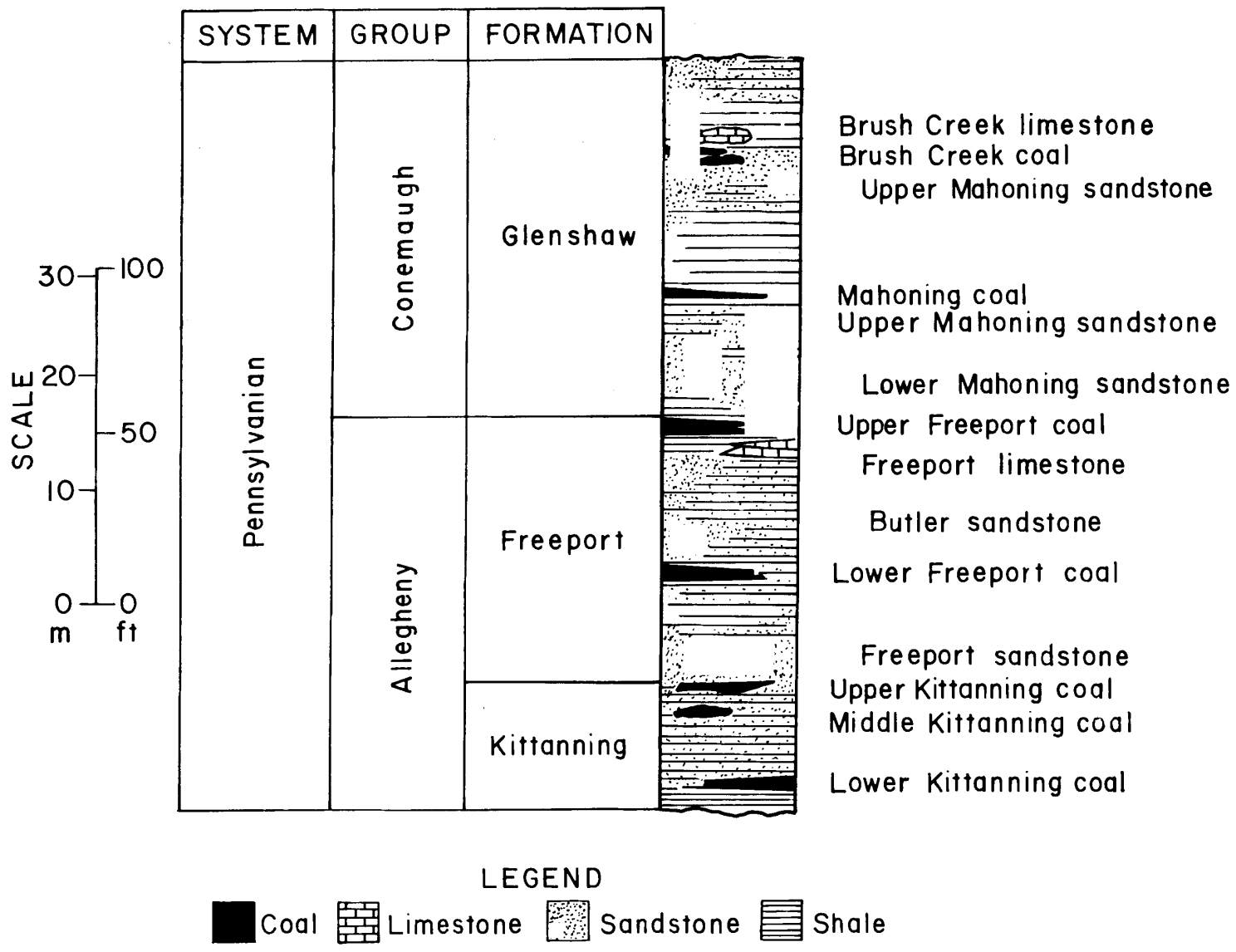

Fig. 2-2. General stratigraphic column of part of the Pennsylvanian system. The Upper Freeport seam is located at the top of the Freeport formation in the Allegheny Group (Figure from Steidl, 1977). 


\section{LEGEND}

臣곤 Limestone Sandstone

㕿国 Limyshole $\square$ Coal

Ei:i: Sandy shale

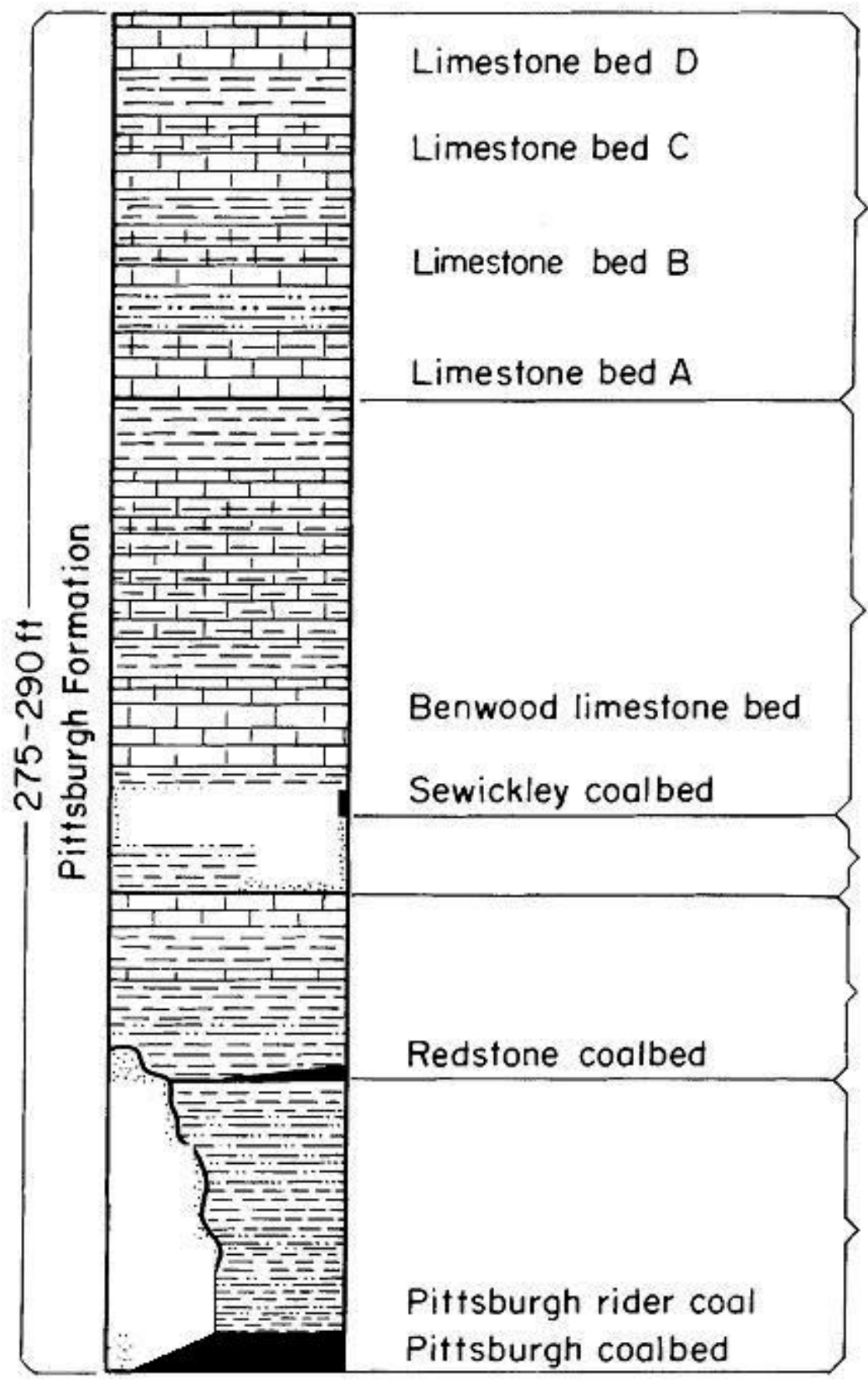

Fig. 2-3. General stratigraphic column of the Upper Pennsylvanian Series. The Pittsburgh coal seam is located at the bottom of the Monongahela Group (Figure from McCulloch et al., 1975). 


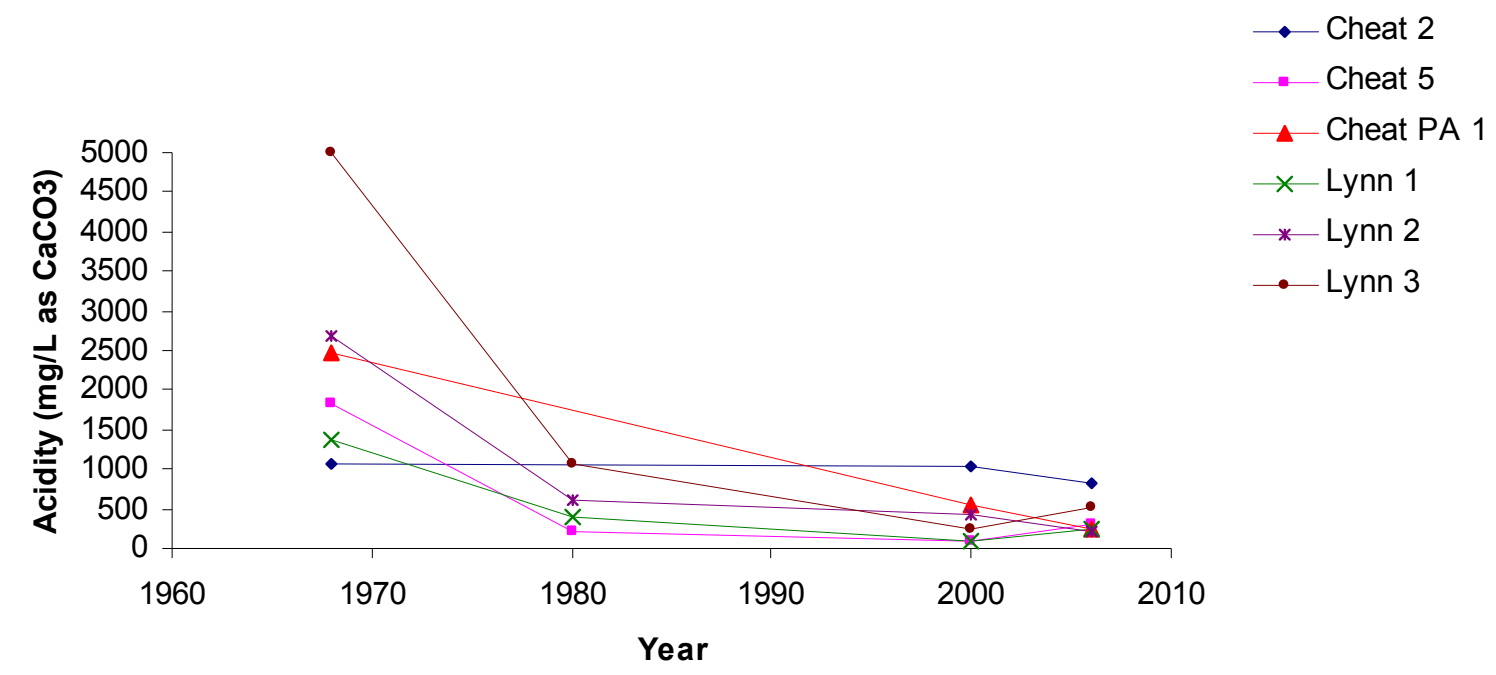

Fig. 2-4. Acidity vs. time for six Pittsburgh sites. All sites showed decreased acidity over time. A line is used to connect sampling points to guide the eye.

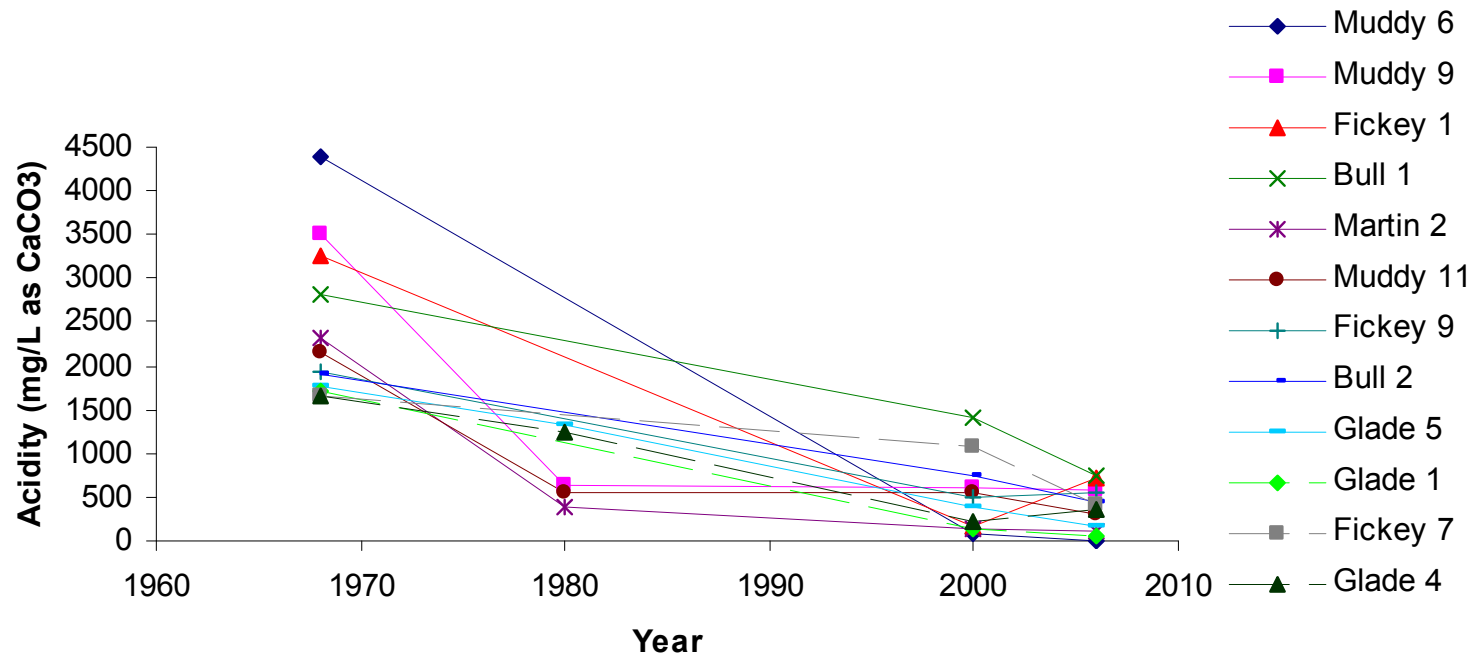

Fig 2-5. Acidity vs. time for 12 Upper Freeport sites. All sites showed decreased acidity over time. A line is used to connect sampling points to guide the eye. 


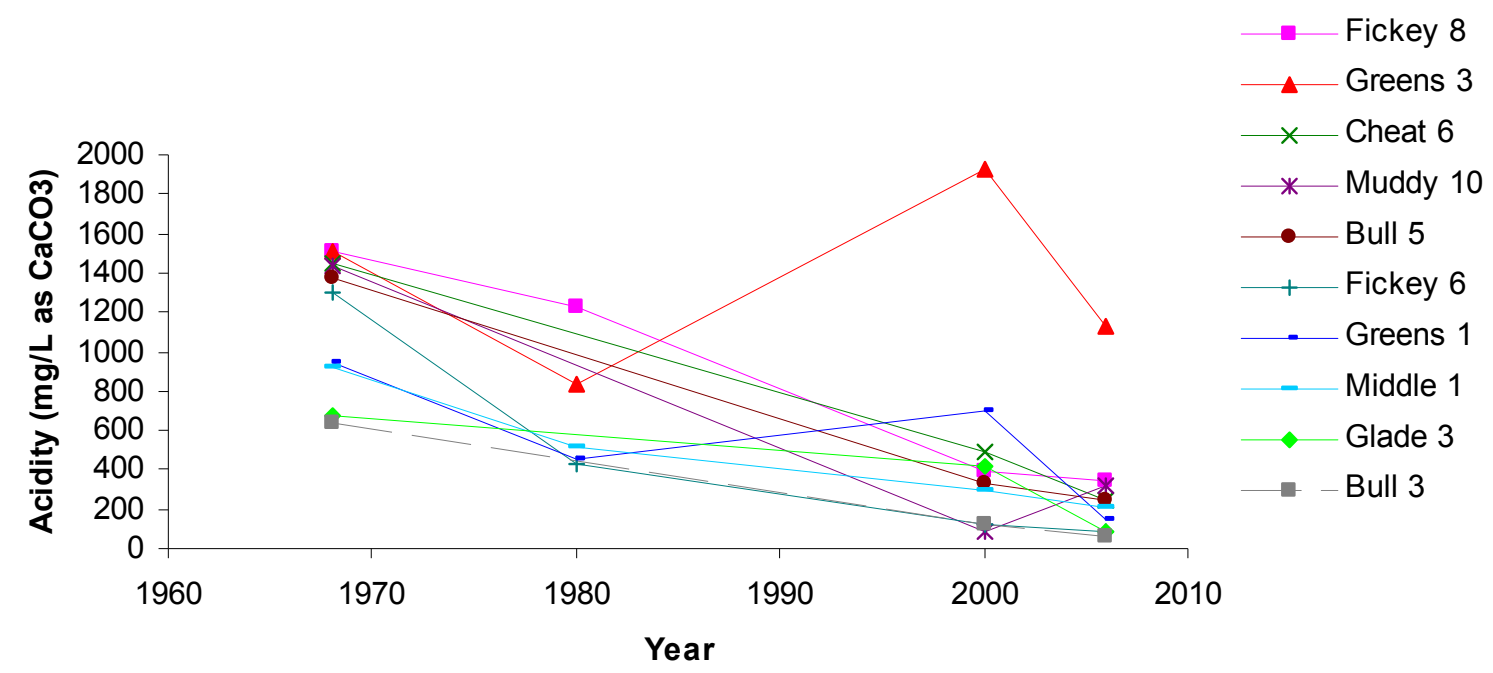

Fig. 2-6. Acidity vs. time for 10 Upper Freeport sites. All sites showed decreased acidity over time. A line is used to connect sampling points to guide the eye.

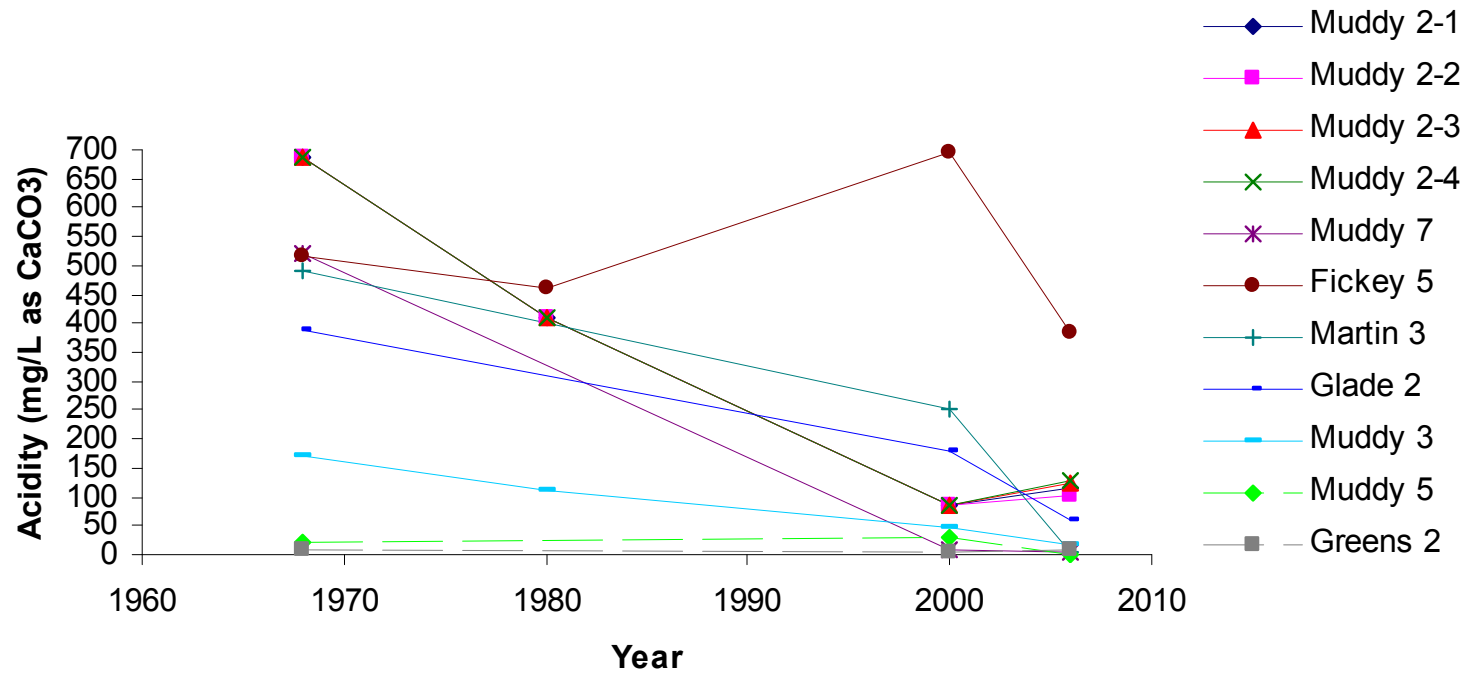

Fig. 2-7. Acidity vs. time for 11 Upper Freeport sites. All sites showed decreased acidity over time. A line is used to connect sampling points to guide the eye. 


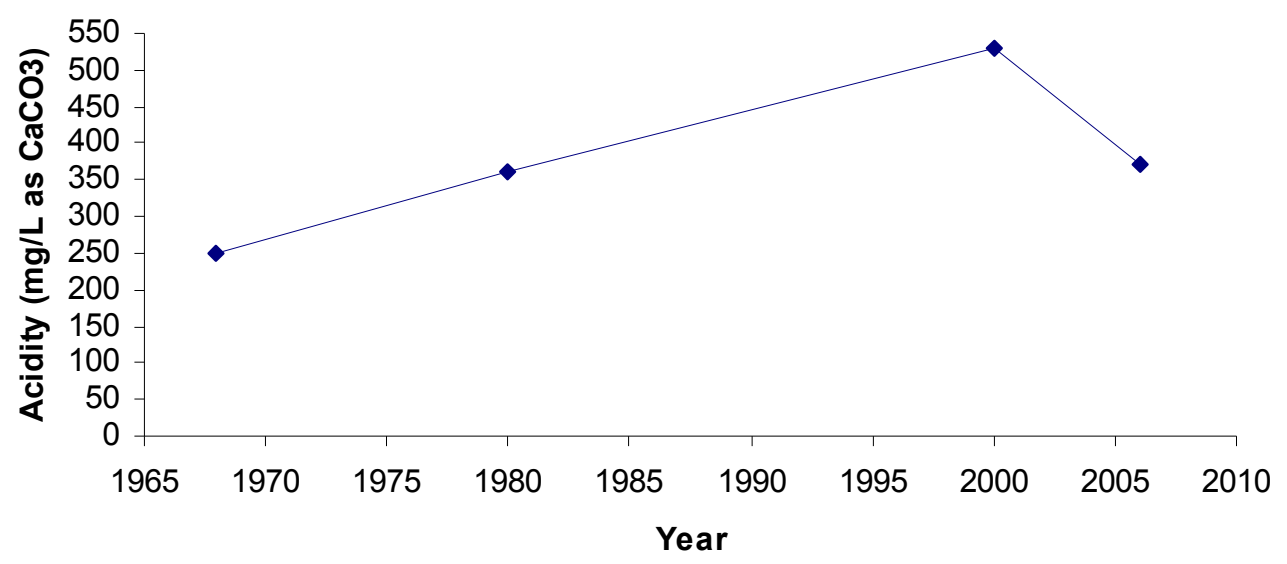

Fig. 2-8. Acidity vs. time for 1 Upper Freeport site. A line is used to connect sampling points to guide the eye.

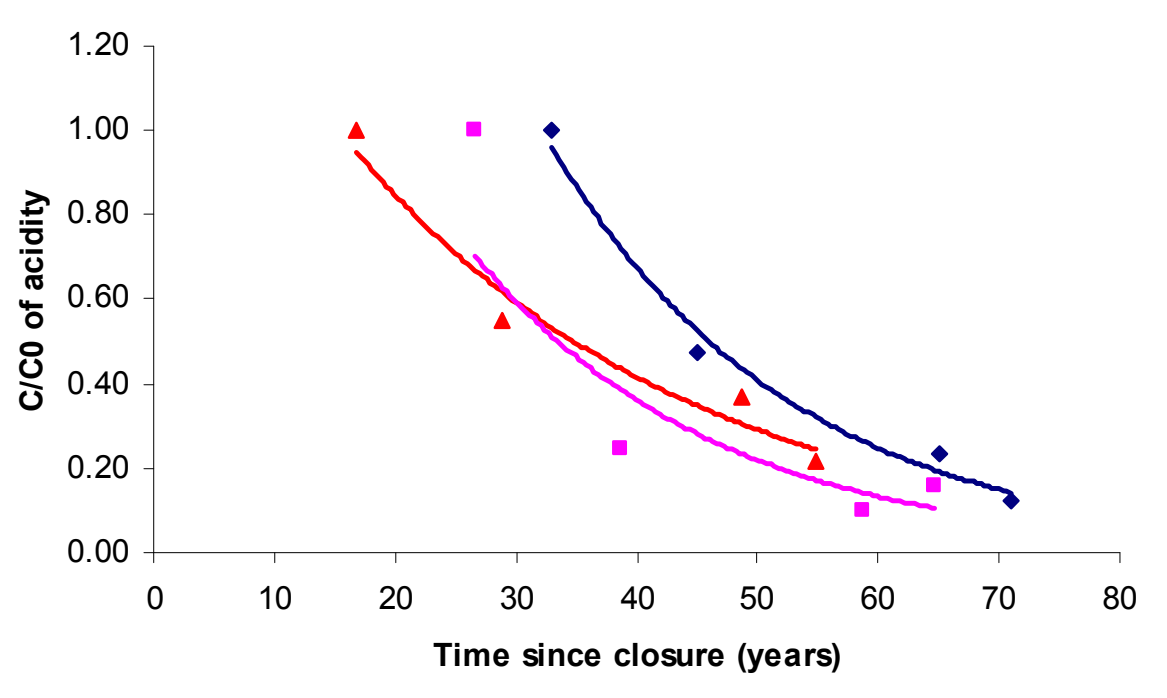

- $1930 \mathrm{~s}$

- $1940 \mathrm{~s}$

- 1950s

-Expon. (1930s)

_Expon. (1950s)

_Expon. (1940s)

Fig. 2-9. Relative acidity $\left(\mathrm{C} / \mathrm{C}_{0}\right)$ vs. time since closure for three different decades of mine closure. Acidity values from the 1968, 1980, 2000, and 2006 sampling dates were divided by acidity values from $1968\left(C_{0}\right)$ to obtain all points. 


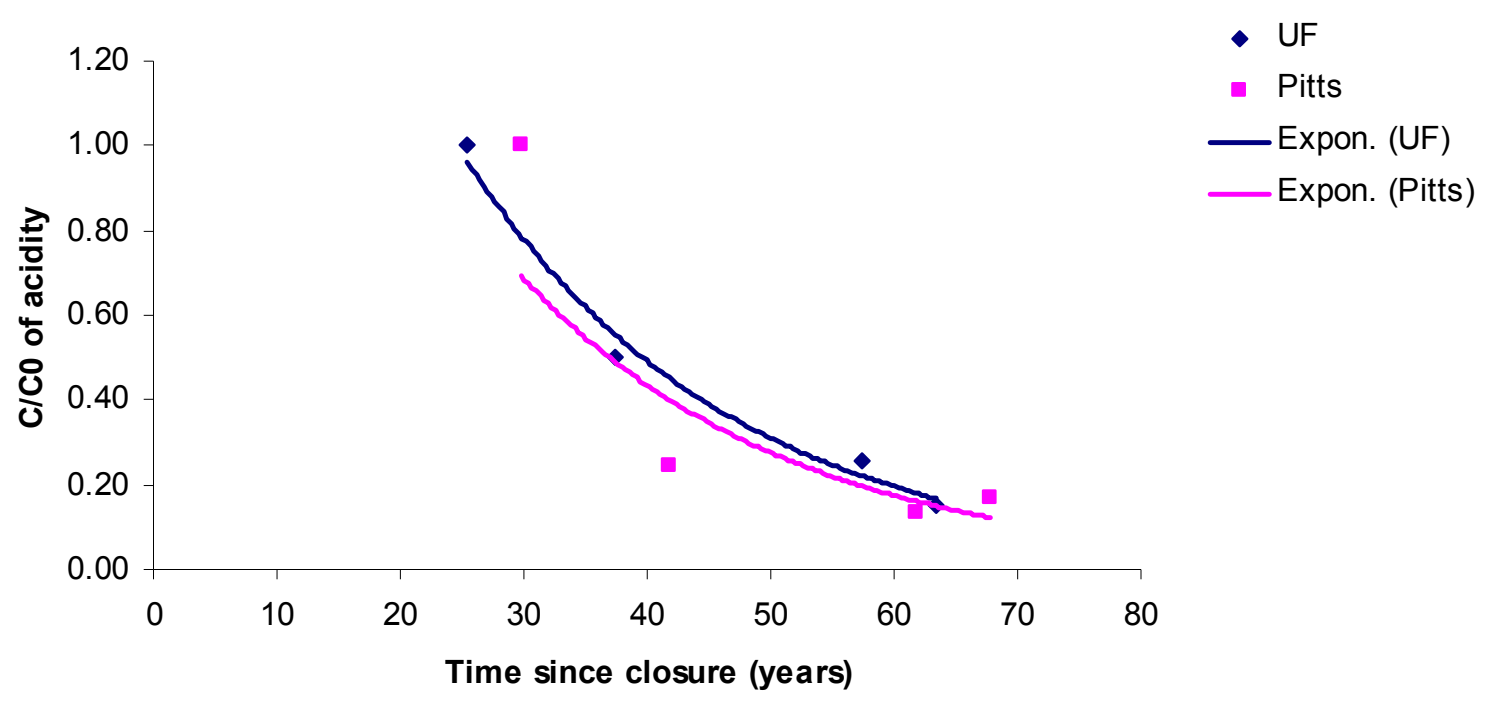

Fig. 2-10. Relative acidity $\left(\mathrm{C} / \mathrm{C}_{0}\right)$ vs. time since mine closure for two different coal seams. Acidity values from the 1968, 1980, 2000, and 2006 sampling dates were divided by acidity values from $1968\left(C_{0}\right)$ to obtain all points.

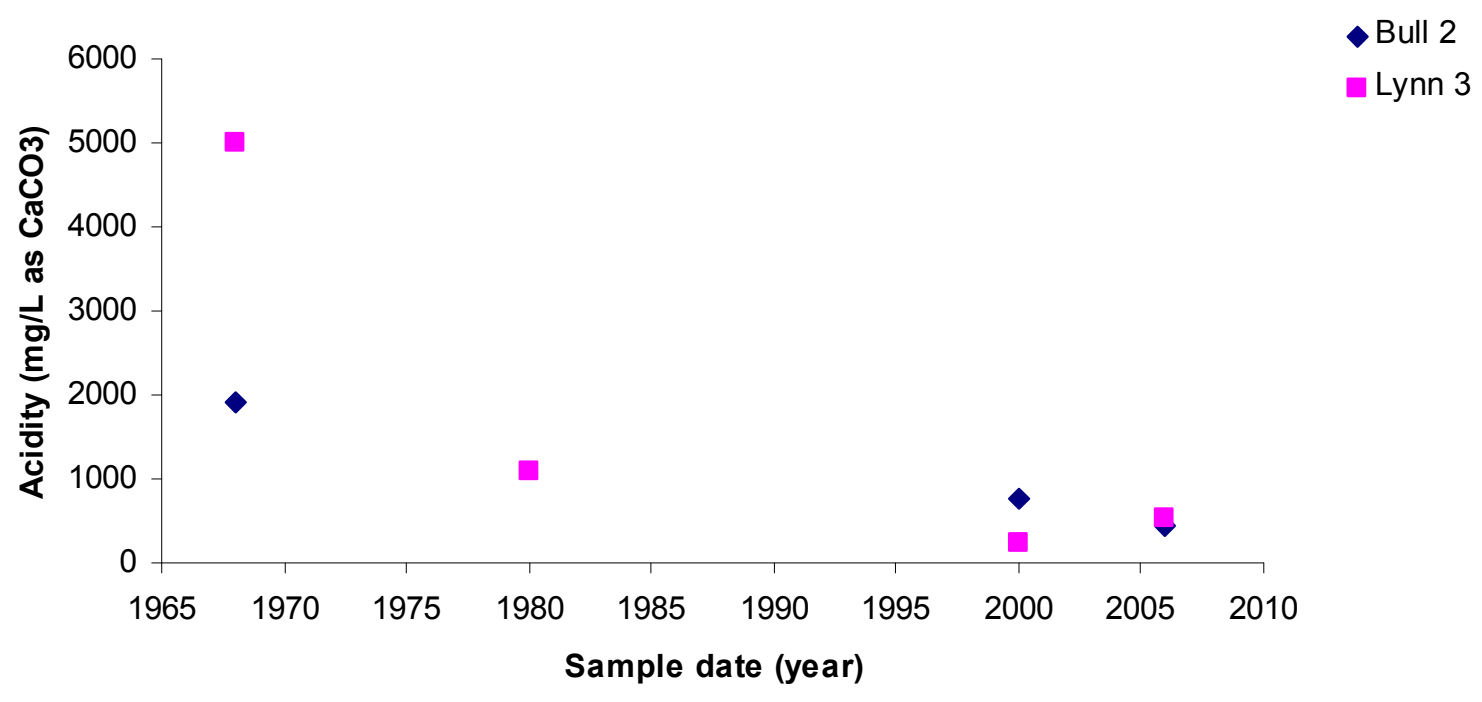

Fig. 2-11. Example of a site with linear acidity decline (Bull 2) and exponential acidity decline (Lynn 3). 

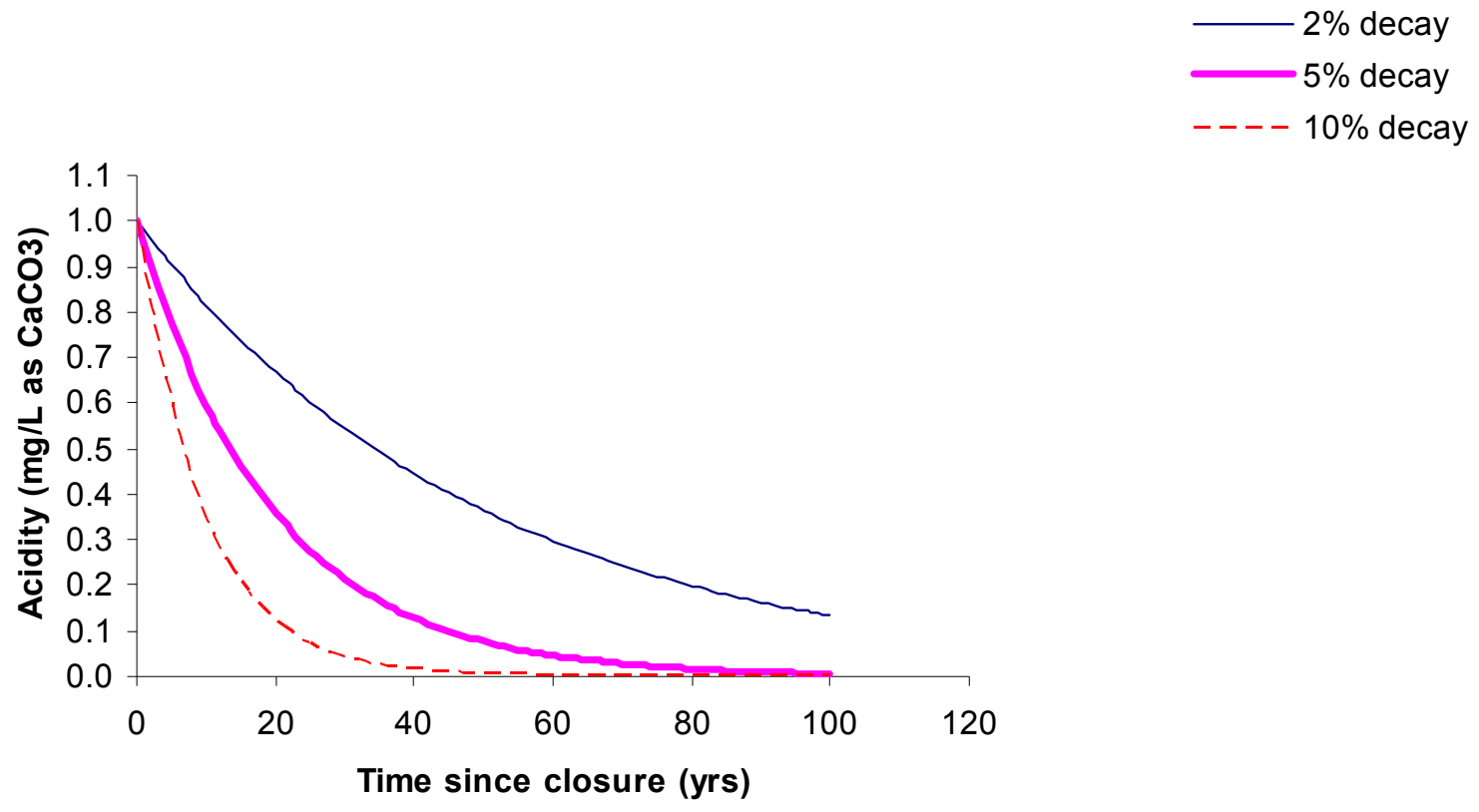

Fig. 2-12. Ideal acidity decay curves of 2, 5, and $10 \%$.

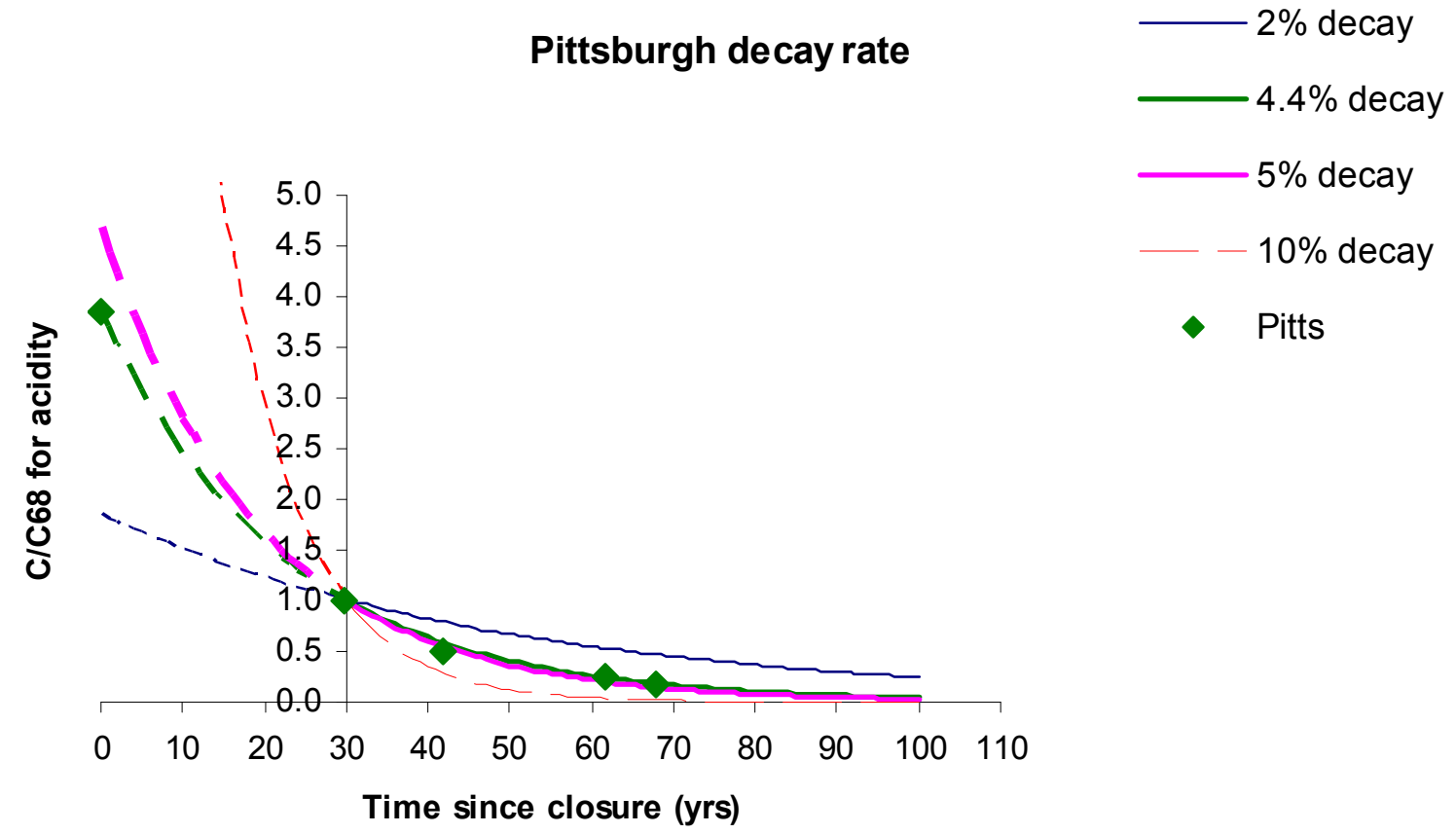

Fig. 2-13. Relative acidity of six Pittsburgh sites vs. ideal decay curves. The decay curve of the Pittsburgh sites is closest to the $5 \%$ decay curve. 


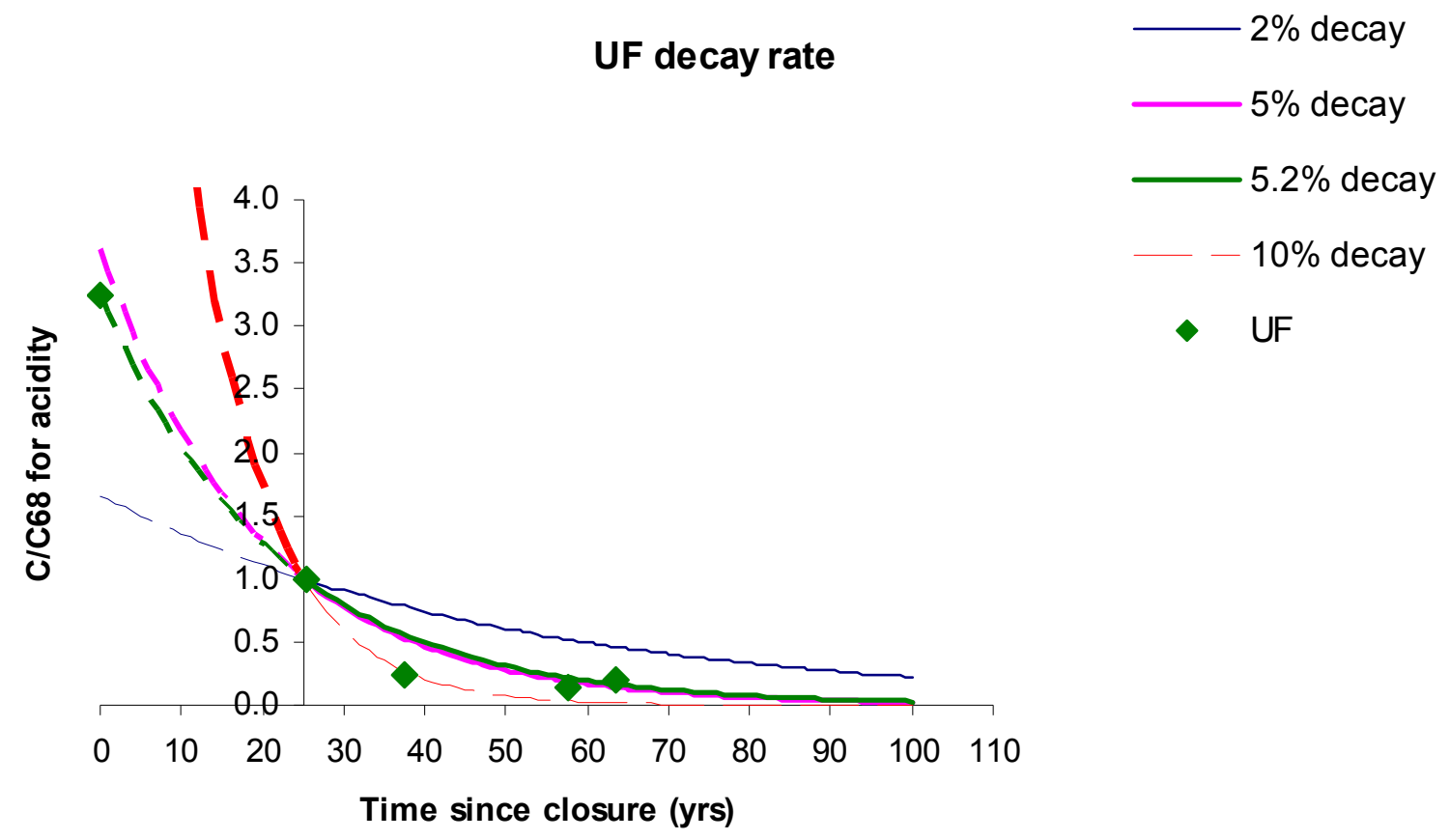

Fig. 2-14. Relative acidity of 34 Upper Freeport sites vs. ideal decay curves. The decay curve of the Upper Freeport sites is closest to the $5 \%$ decay curve.

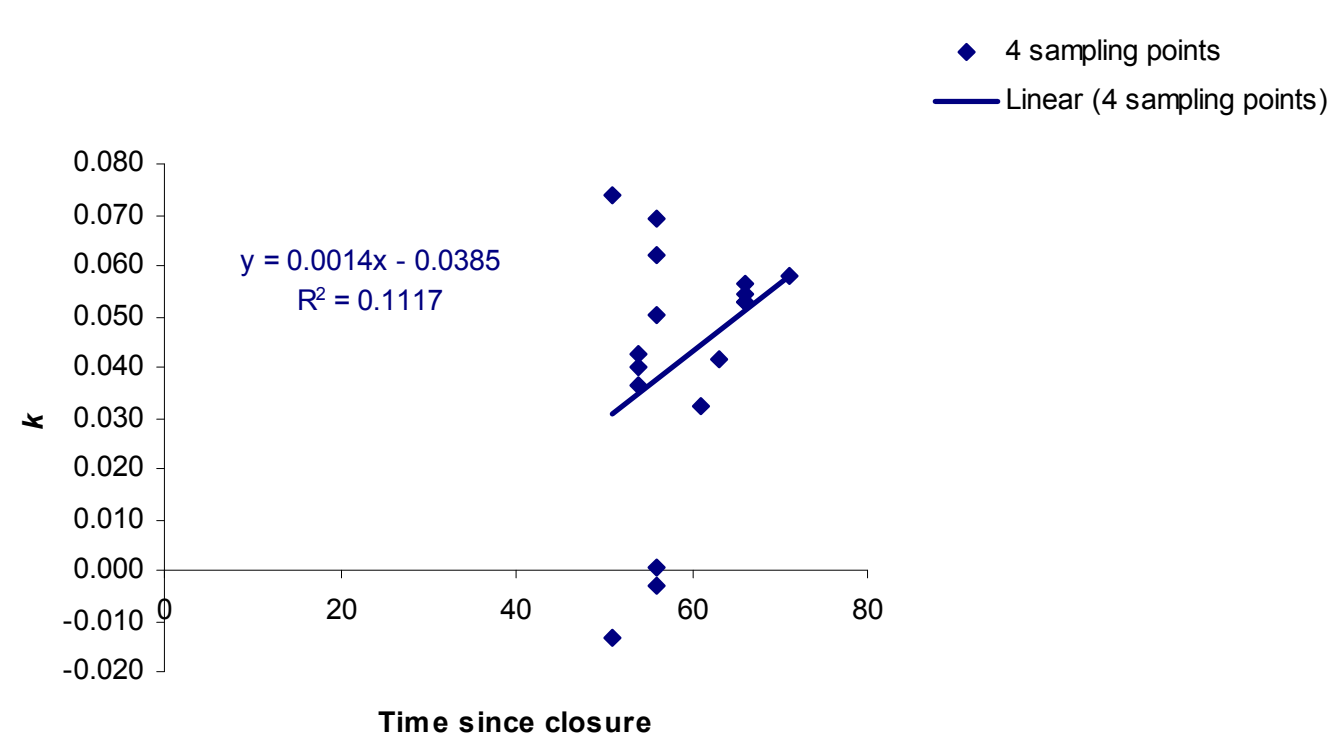

Fig. 2-15. Decay rate values vs. time since mine closure for mines sampled four times. The low $R^{2}$ value and the wide spread of the points indicate a poor relationship between decay rates and time since closure. 


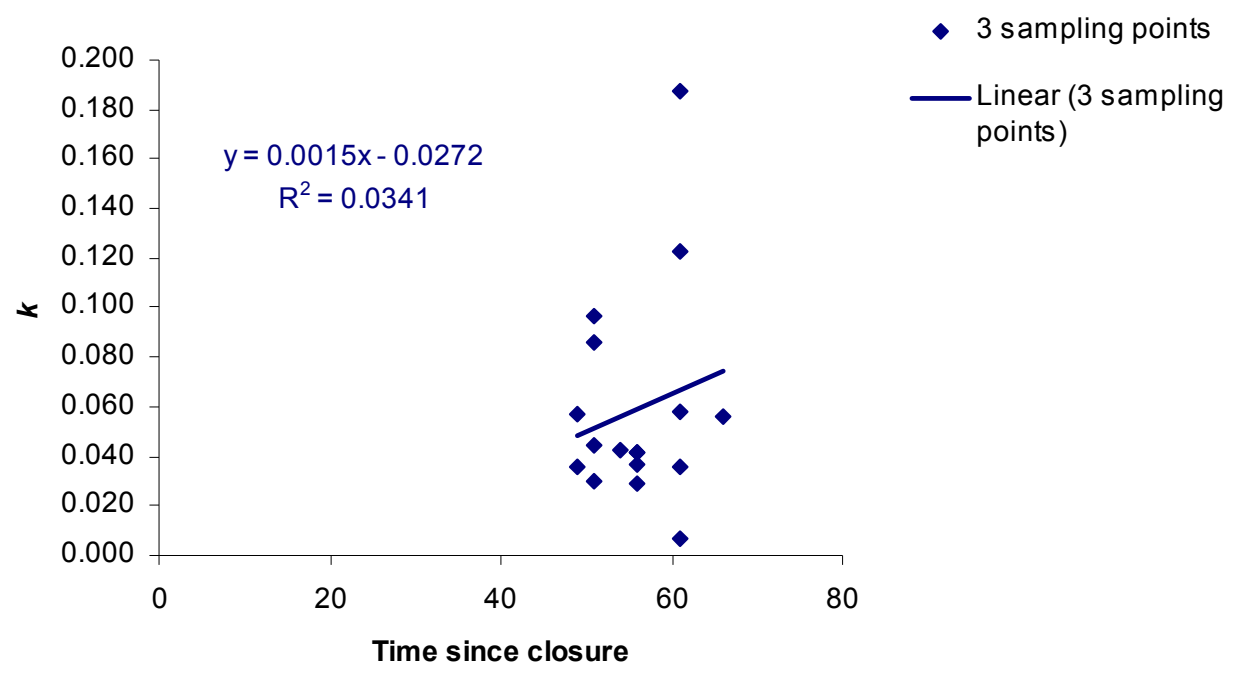

Fig. 2-16. Decay rate values vs. time since mine closure for mines sampled three times. The low $R^{2}$ value and the wide spread of the points indicate a poor relationship between decay rates and time since closure.

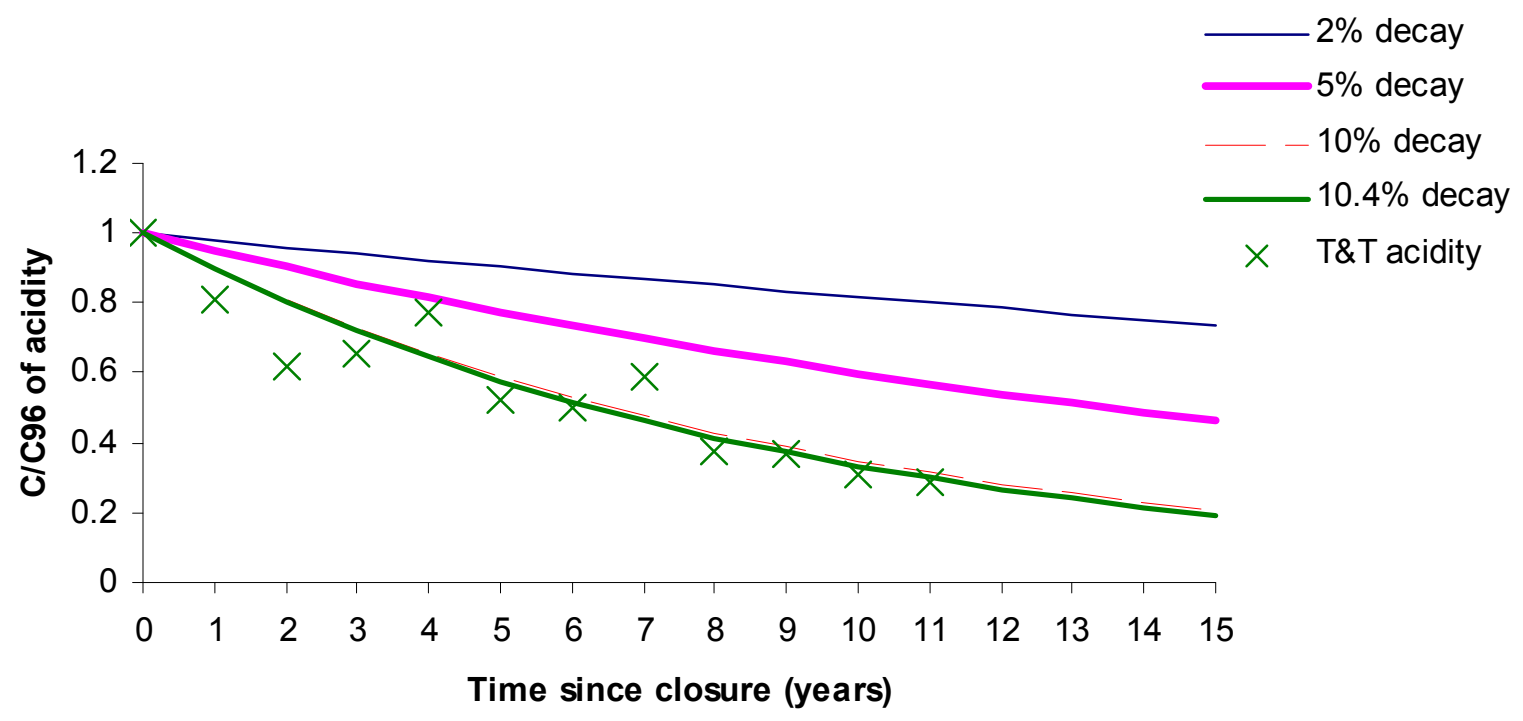

Fig. 2-17. Relative acidity of T\&T \#2 vs. ideal decay curves. T\&T's decay curve is closest to the $10 \%$ decay curve. 


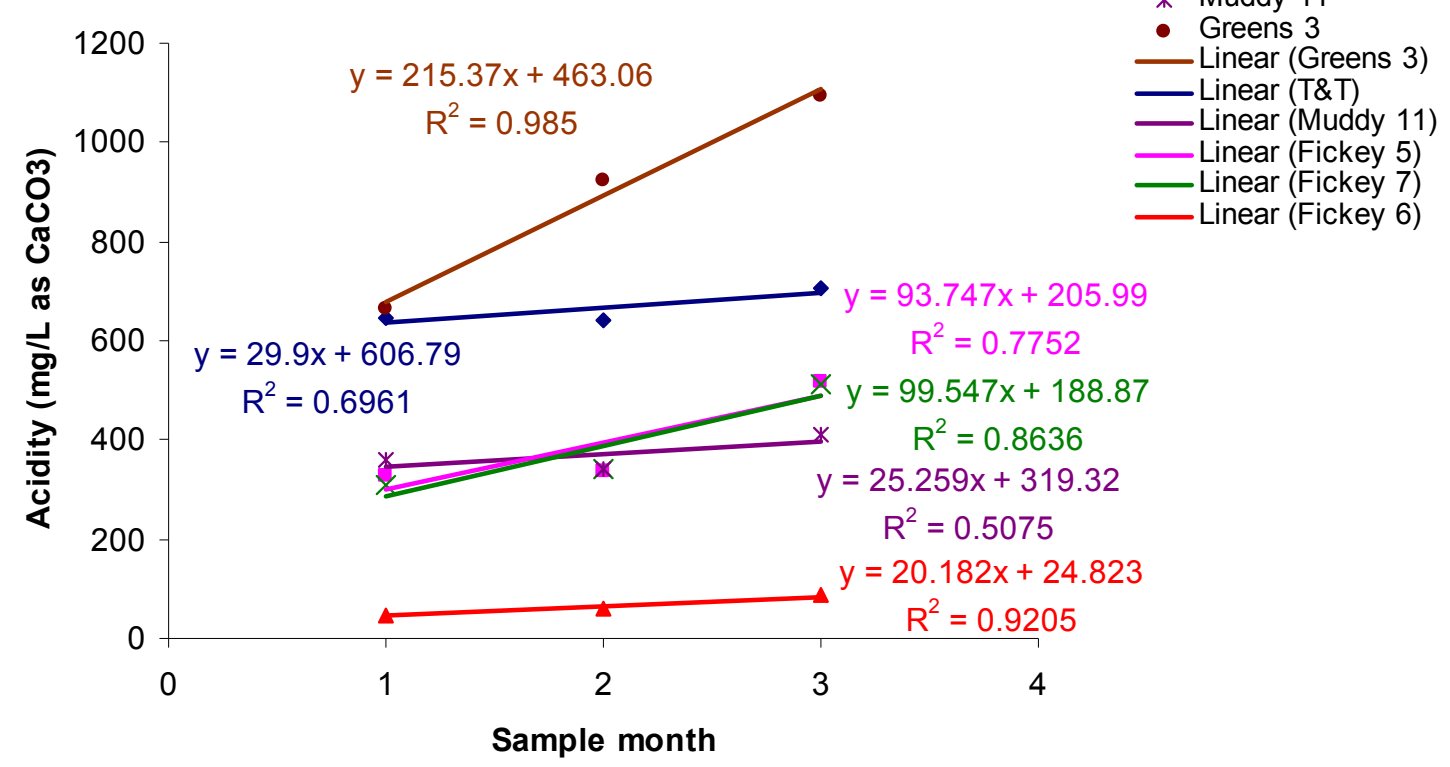

Fig. 2-18. Mean acidity concentrations for $T \& T$ and 5 other Upper Freeport sites. Month 1= March, Month 2= May, and Month 3= July. All sites showed increased acidity over time.

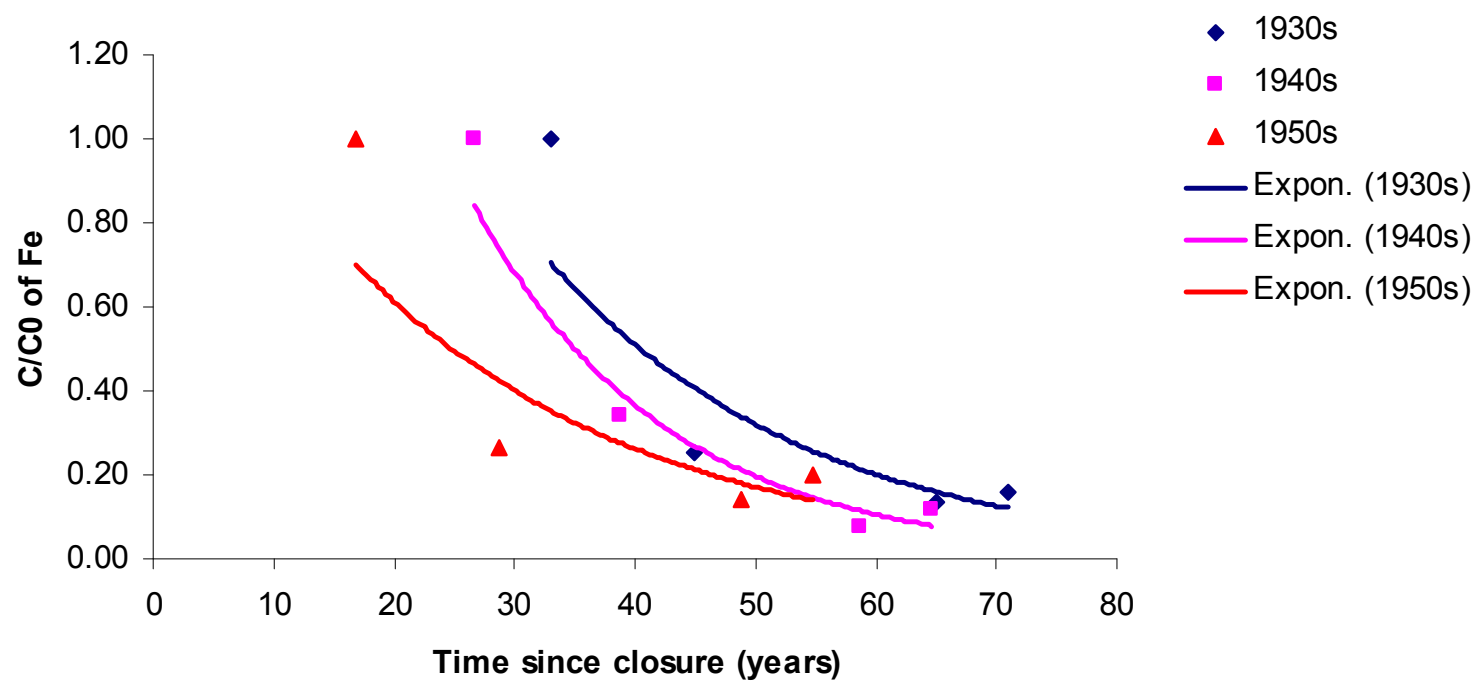

Fig. 2-19. Relative Fe concentrations $\left(\mathrm{C} / \mathrm{C}_{0}\right)$ vs. time since mine closure for three decades of mine closure. Fe values from the 1968, 1980, 2000, and 2006 sampling dates were divided by $\mathrm{Fe}$ values from $1968\left(\mathrm{C}_{0}\right)$ to obtain all points. 


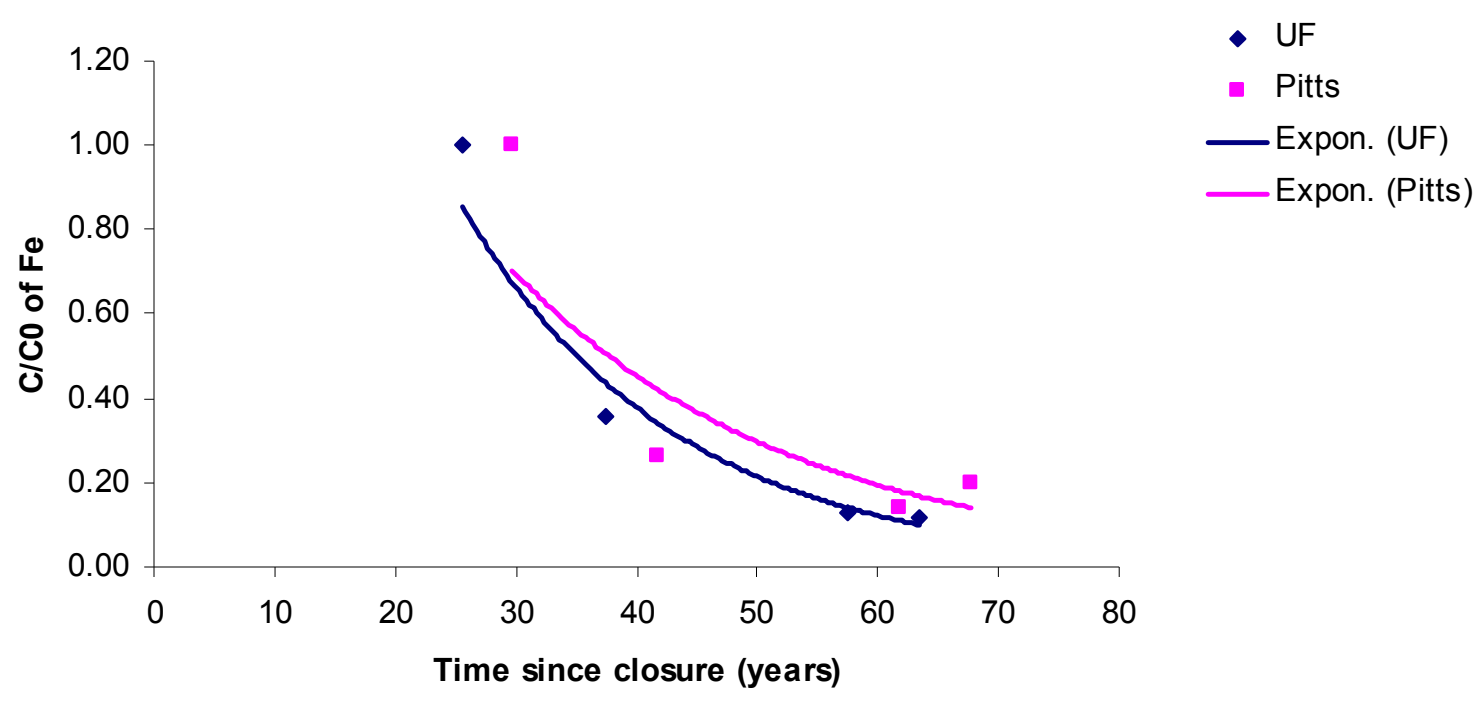

Fig. 2-20. Relative Fe concentrations $\left(C / C_{0}\right)$ vs. time since mine closure for two coal seams. Fe values from the 1968, 1980, 2000, and 2006 sampling dates were divided by Fe values from $1968\left(C_{0}\right)$ to obtain all points.

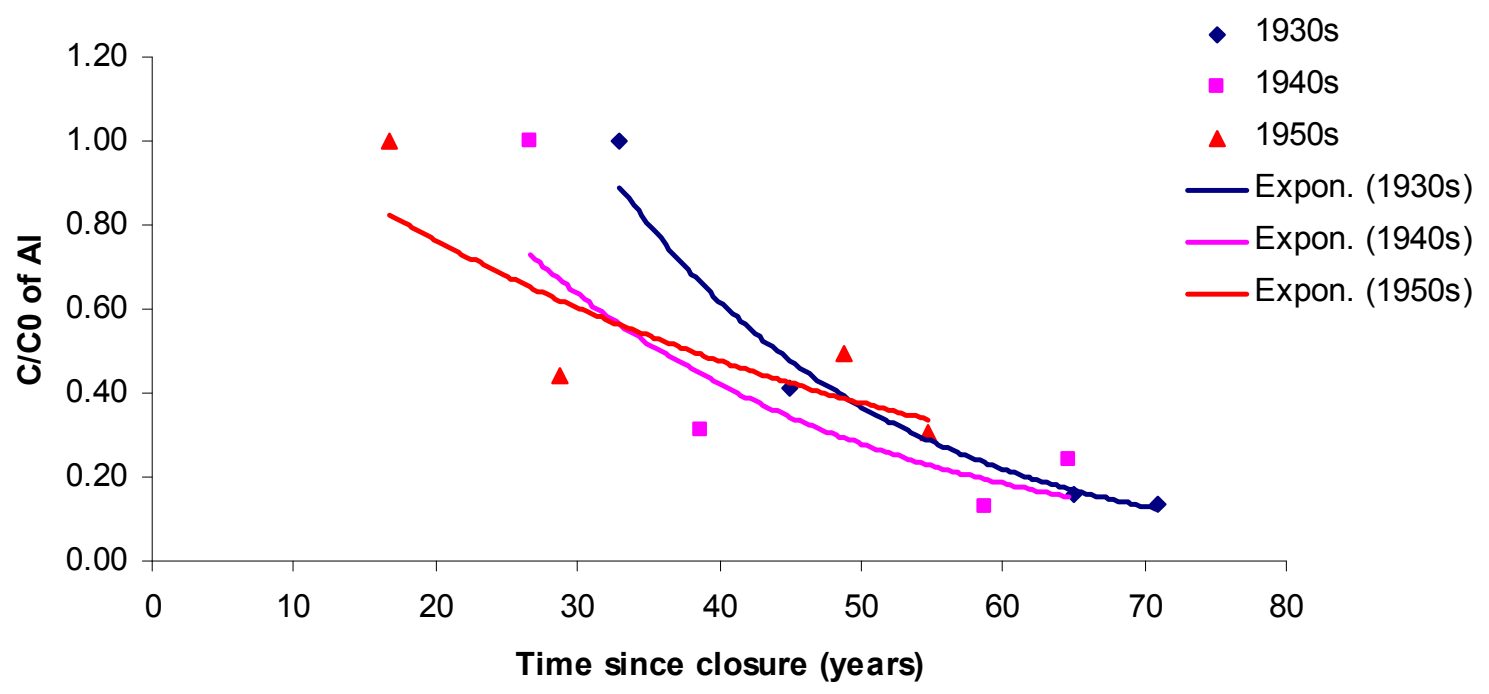

Fig. 2-21. Relative $A l$ concentrations $\left(C / C_{0}\right)$ vs. time since mine closure for three decades of mine closure. Al values from the 1968, 1980, 2000, and 2006 sampling dates were divided by $A l$ values from $1968\left(C_{0}\right)$ to obtain all points. 


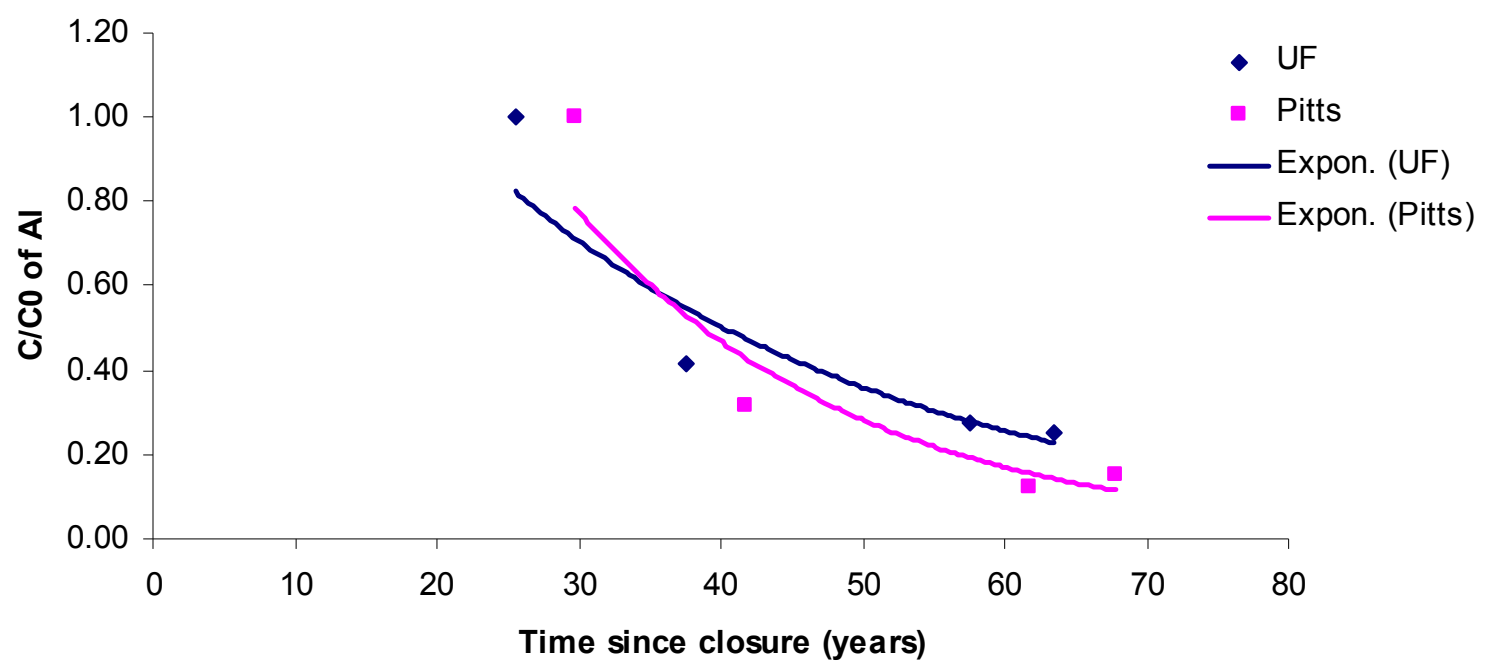

Fig. 2-22. Relative $A l$ concentrations $\left(C / C_{0}\right)$ vs. time since mine closure for two coal seams. Al values from the 1968, 1980, 2000, and 2006 sampling dates were divided by Al values from $1968\left(C_{0}\right)$ to obtain all points.

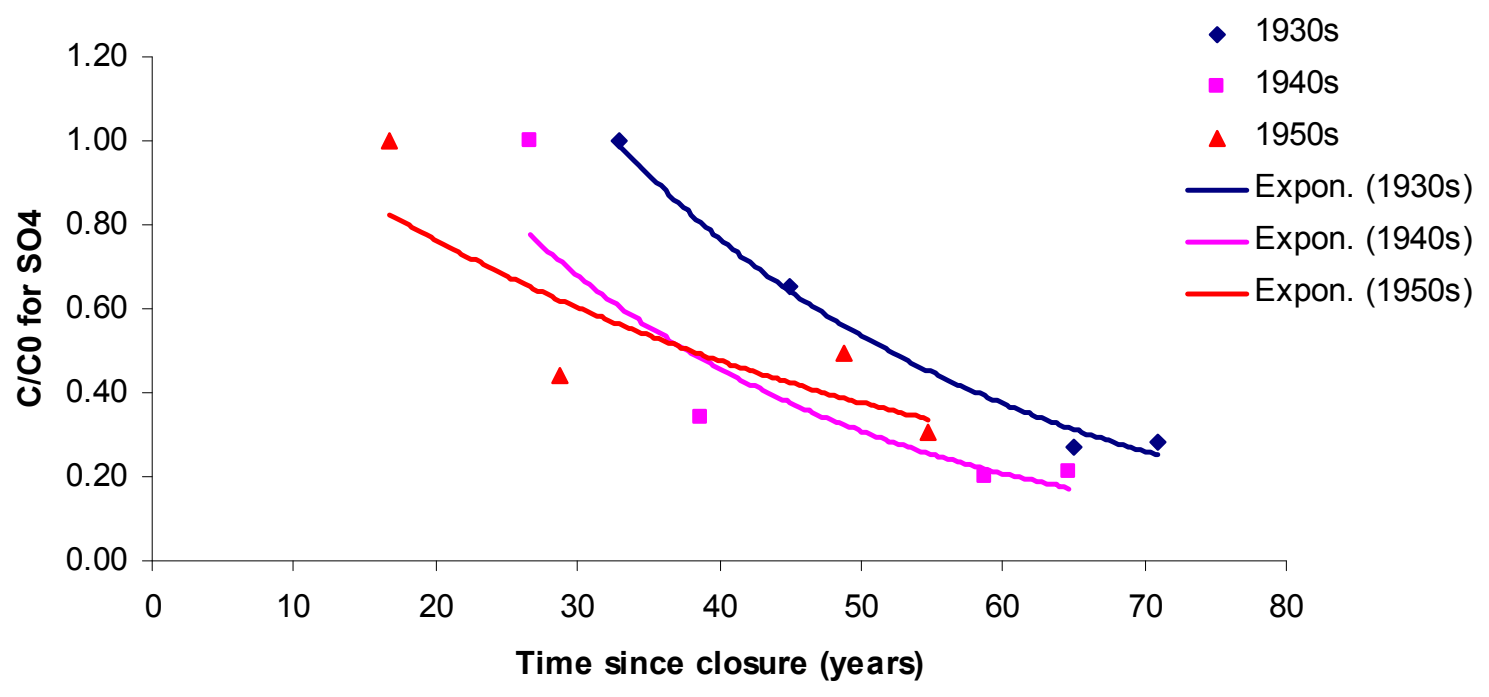

Fig. 2-23. Relative $\mathrm{SO}_{4}$ concentrations $\left(\mathrm{C} / \mathrm{C}_{0}\right)$ vs. time since mine closure for three decades of mine closure. $\mathrm{SO}_{4}$ values from the 1968, 1980, 2000, and 2006 sampling dates were divided by $\mathrm{SO}_{4}$ values from $1968\left(\mathrm{C}_{0}\right)$ to obtain all points. 


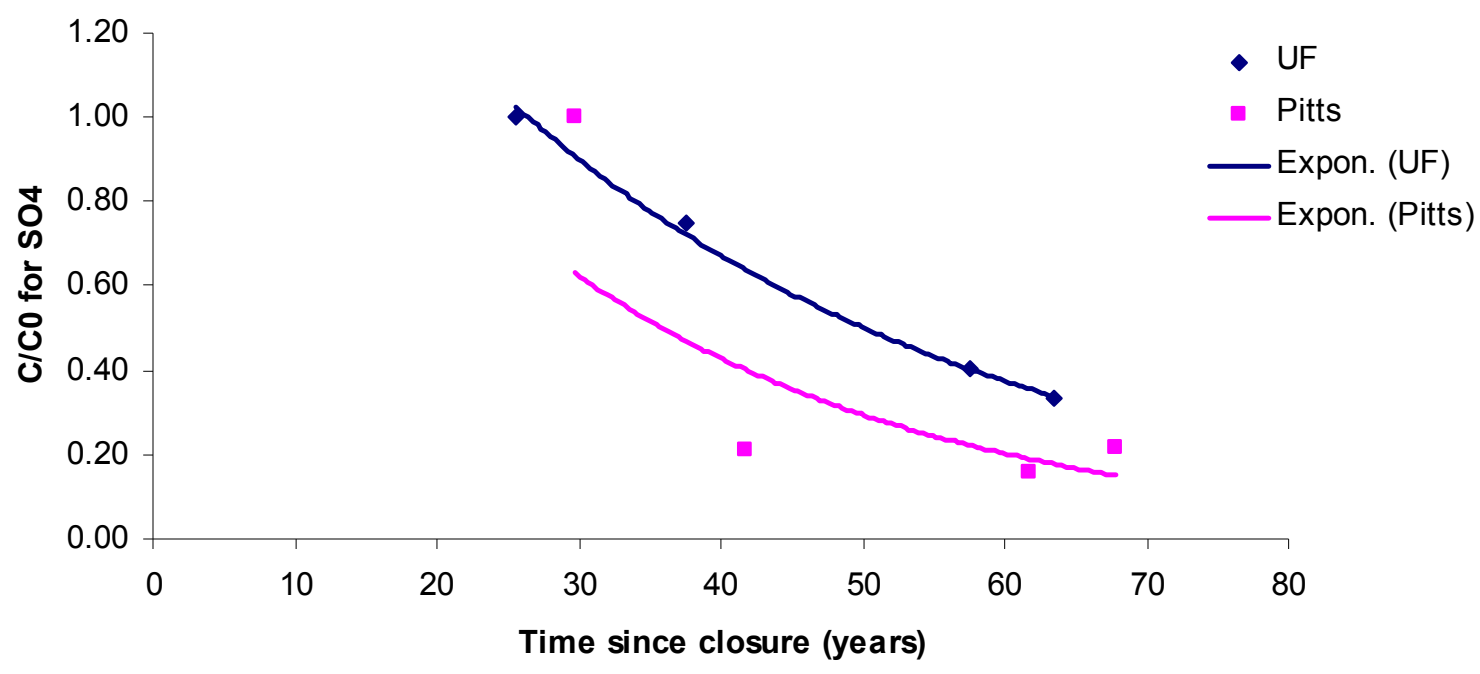

Fig. 2-24. Relative $\mathrm{SO}_{4}$ concentrations $\left(\mathrm{C} / \mathrm{C}_{0}\right)$ vs. time since mine closure for two coal seams. $\mathrm{SO}_{4}$ values from the 1968, 1980, 2000, and 2006 sampling dates were divided by $\mathrm{SO}_{4}$ values from $1968\left(\mathrm{C}_{0}\right)$ to obtain all points.

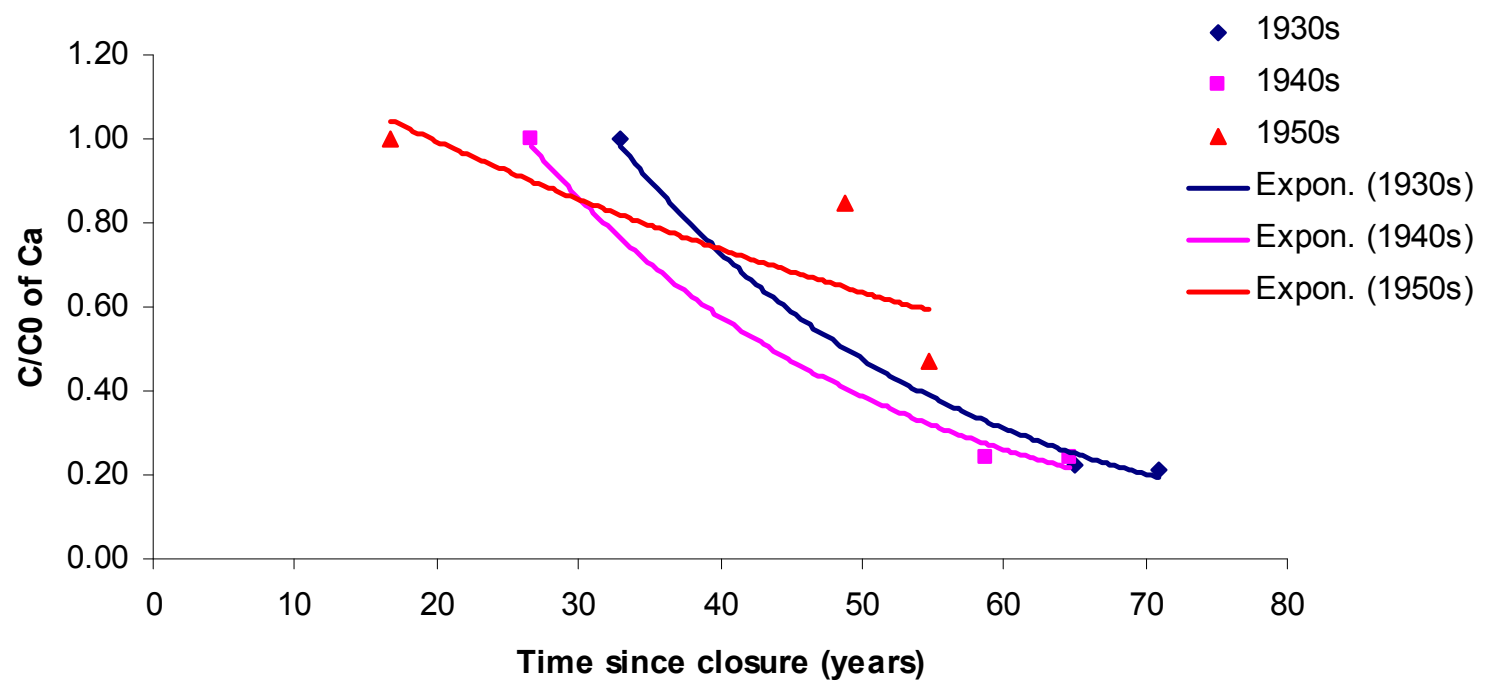

Fig. 2-25. Relative Ca concentrations $\left(\mathrm{C} / \mathrm{C}_{0}\right)$ vs. time since mine closure for three decades of mine closure. Ca values from the 1968, 1980, 2000, and 2006 sampling dates were divided by $\mathrm{Ca}$ values from $1968\left(\mathrm{C}_{0}\right)$ to obtain all points. 


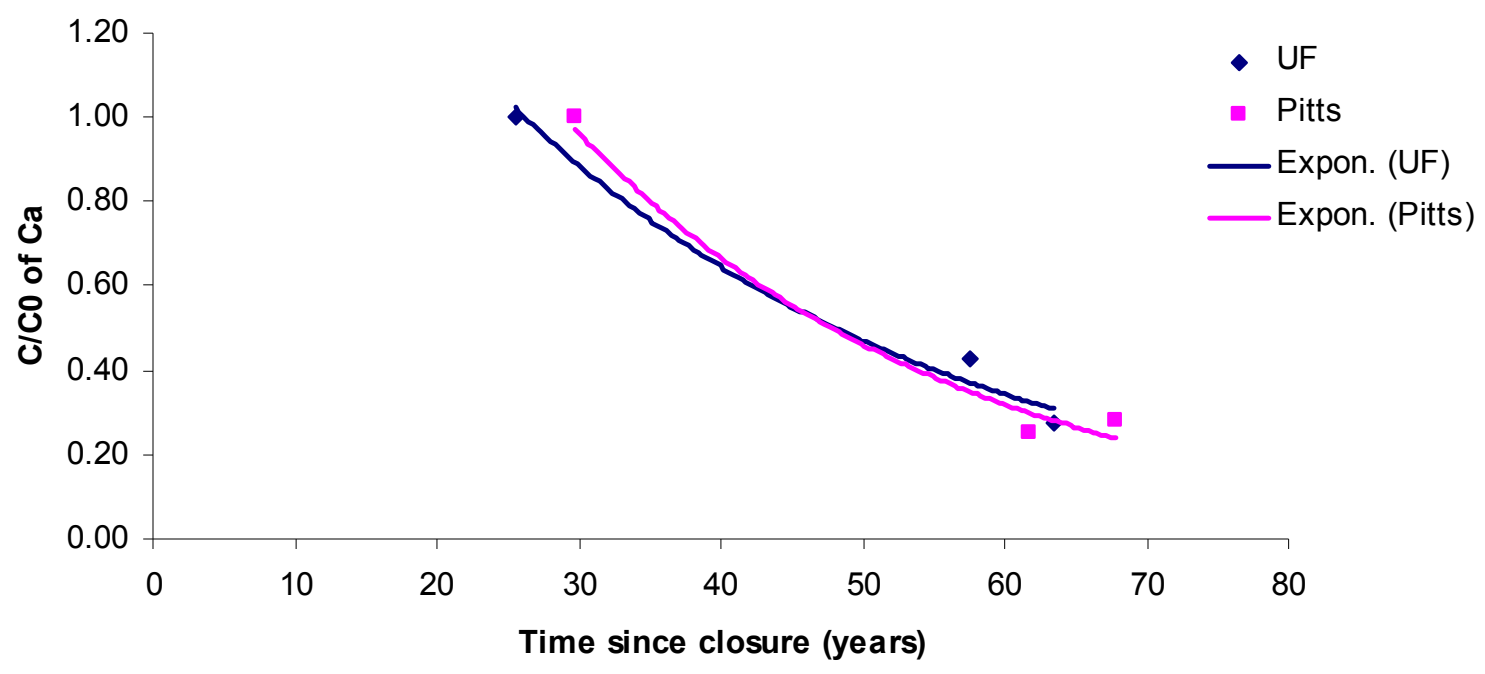

Fig. 2-26. Relative Ca concentrations $\left(C / C_{0}\right)$ vs. time since mine closure for two coal seams. Ca values from the 1968, 1980, 2000, and 2006 sampling dates were divided by Ca values from $1968\left(C_{0}\right)$ to obtain all points. 


\section{CHAPTER 3: INTENSIVE SAMPLING TO DETERMINE CHANGES IN FLOW AND WATER CHEMISTRY OVER VARYING TIME SPANS}

\section{$\underline{\text { Introduction }}$}

It is known that the flow from underground mines in this region of Appalachia is affected by seasonal variations in rain and snowfall. Rainfall recharges the groundwater, resulting in increased flows from discharge points. McDonough et al. (2005) found that the M-59 discharge in the Uniontown Syncline of Pennsylvania followed a seasonal variation in discharge amounts, with lower flows in the summer months and the highest flows in the spring months. Wendland (2001) showed that groundwater reacted to rainfall within a month or two, depending on the season. Highest flows from the above-drainage T\&T mine in northern West Virginia occurred from March - June (400 L/s), with much lower flows on average from July to February $(280 \mathrm{~L} / \mathrm{s})$ (Demchak et al., 2004).

A study by Lopez and Stoertz (2001) of three above-drainage, underground mines that had different areas, discharge rates and contaminant concentrations, found a 1 to 4 day lag between the rain event and the maximum discharge from the portal. However, Borek et al. (1991) found that high flow values were seen even when rainfall was below normal. However, these discharges in the Borek et al. study were from sealed underground mines, which allowed the flows to be discharged more evenly.

Seasonal changes in flow can have a large effect on AMD chemistry. In the Mid-Atlantic region, there are usually two distinct seasons; March-June and July-November. More rainfall is usually received in March-June than July-November. Flow values are typically higher during spring, which translates to higher flows from underground mines during that time period as well.

One of the ways that seasonal changes in flow can influence AMD is by the concept of the "spring flush." A study of the 51-ha Majestic mine in Ohio by Pigati and Lopez (1999) showed that larger flows in the spring scoured metal salts from the interior of the mine and "flushed" them out with the water discharge. This caused an increase in acidity and metal concentrations due to the higher flow. Desbarats and Dirom (2007), during their study of the Maya mine in British Columbia, found that small spikes in mine flow were found during the summer months after storm events. However, the highest spikes in metal concentrations in this mine were during the initial heavy rains in autumn. Seasonal changes in metal concentrations will also affect acidity concentrations in AMD. The Omega mine, an above-drainage mine in West Virginia, had water samples taken continuously for six years. Acidity values were consistently higher (roughly 4,500 
$\mathrm{mg} / \mathrm{L}$ ) between February and May, when there were higher flows. By contrast, June - January showed lower acidities (roughly 3,500 mg/L), as well as lower flow values (Demchak et al., 2004). In general, above-drainage mines seem to support the "spring flush" theory. The T\&T mine, on the other hand, had similar acidity values between these two seasons (March-June $=18 \mathrm{mmol} \mathrm{H}^{+} / \mathrm{L}$ and July-November $\left.=17.5 \mathrm{mmol} \mathrm{H}^{+} / \mathrm{L}\right)$.

In contrast, the "higher concentration at lower flow" theory suggests that acidity and metal concentrations will increase during times of low flow. This is because there is less water to dilute the metals dissolved in the water (Skousen and Ziemkiewicz, 1996). A study by Griffiths et al. (2001) at the Arnot mine in Pennsylvania found that acidity decreased as flow increased. However, many small flushing events were found, which may have skewed the results. Stillings (2006) found that the concentrations of the major metal elements (as measured by conductivity) in the Beatson mine in Alaska decreased after major rain events. However, the concentrations of trace elements, such as $\mathrm{Cu}$ and $\mathrm{Zn}$, had increasing concentrations with higher flows. This was due to a greater reaction rate because of increased wetting of reactive surfaces at higher flows. Due to the contradicting nature of many of these studies, more research is needed to evaluate the effects of flow on water chemistry in underground mines.

\section{$\underline{\text { Objectives }}$}

There were two main objectives for this research. The first objective was to determine the changes in flow and acidity for varying time scales. Variations in flow over various time spans could affect water chemistry differently, depending on the time between samples. The second objective was to assess the interactions between acidity and flow. The relationship between acidity and flow is important to treating AMD discharges, as well as estimating future water quality of a given discharge.

\section{Materials and Methods}

Five abandoned underground, above-drainage mine sites were selected for water sampling in the summer of 2006 (Fig. 3-1). These sites were part of the set of 40 sites referred to in Chapter 2 of this thesis. They were selected for this research because historic data were associated with them and they were easy to access for repeated water sampling. Water sampling in 1968, 1980, and 2000 on these sites provided the baseline data to be used in this study. The sites were located in Preston County, WV. All five mines removed coal from the Upper Freeport coal seam. 
Water sampling was performed in three different months: March 2007, May 2007, and July 2007. All five sites were sampled two times per week for three weeks in March, and three times per week for three weeks in May and July. Flow was determined and water samples were taken at every sampling time.

Flows were measured by stretching a measuring tape across the width of the discharge and dividing the stream into sections. Each section was between $10-20 \%$ of the overall width of the discharge, so that there were at least five measurement points for each discharge. Depth at each sampling point was measured using the 0.6 depth method (Buchanan and Somers, 1976). Velocity at each sampling point was found using a Marsh-McBirney Flo-Mate 2000 (Marsh-McBirney, Frederick, MD). The width interval, depth, and velocity were multiplied together at each point in order to determine flow. Total flow for the discharge was found by adding the flow values from each sampling point together. For discharges where the use of a flow meter was not practical, flows were determined by the bucket and stopwatch method. A bucket pre-marked at $2 \mathrm{~L}$ was filled with water. The amount of time needed to fill the bucket to the $2 \mathrm{~L}$ mark was recorded. This procedure was performed three times for each discharge and the values were averaged together to get the final flow value.

Water $\mathrm{pH}$ was determined by a Milwaukee Sharp $\mathrm{pH}$ meter (Milwaukee Meters, Southport, Australia) in the field and an Accumet Model 15 pH meter (Fisher Scientific, Hampton, NH) in the laboratory. Conductivity was measured by a Milwaukee Sharp EC meter (Milwaukee Meters, Southport, Australia) in the field and a WTW LF 3000 (WTW, Weilheim, Germany) in the laboratory. Field measurements were used in the final analysis. Both acidity and alkalinity were determined by a digital titrator from a HACH model AL-DT kit (HACH Company, Loveland, CO). For comparison, acidity was also determined by using the mathematical equation for calculated acidity (Kirby and Cravotta, 2004). Calculated acidity values were used in the final analysis. Metal concentrations were determined using an Inductively Coupled Spectrophotometer, Plasma 400 (Perkin Elmer, Norwalk, CT). Sulfate was determined turbidimetrically by flow injection analysis using a Latchat Quik Chem FIA+, 8000 series (Latchat Instruments, Milwaukee, WI).

\section{Data Analysis}

Principal Components Analysis (PCA) was used to determine the number of factors, or eigenvalues, which would be analyzed in the Factor Analysis (FA). Eigenvalues are defined as the variance of the factors. The raw flow values, as well as the raw cation and anion concentrations, were used in the PCA to determine the number of eigenvalues to be used in the FA. All eigenvalues greater than 1 were used in the FA for each of the five sites. The FA was then used to 
show relationships between flow, acidity, and other sampled parameters. A nested ANOVA was also used to determine significant differences among changes in flow and acidity over the time spans of a week and a month for these sampling sites.

Due to a missing week of data in March, only six water samples were used in the final analysis for the month of March. Because of this, mean values for both flow and acidity were weighted more toward the months of May and July.

\section{Results and Discussion}

Descriptive statistics were calculated for both flow and acidity and are provided in Table 31.

Flow

Flow differences among sites ( $\mathrm{p}<0.0001)$, sampling month $(\mathrm{p}<0.0001)$, and the interaction of sample sites with months ( $\mathrm{p}<0.0001)$ were all found to be significant (Table 3-2). The average flows for sampling weeks within a month were also significantly different.

Since each mine had different underground mine areas to collect water, flow values among sites were widely variable over the course of the three-month sampling period and were expected to be significantly different (Table 3-1). Muddy 11 (453 ha) had the highest average flow value of the three-month sampling period, while Fickey 6 (5 ha) and Green 3 ( 2 ha) had the lowest average flows (Table 3-3).

Further analysis showed that mean flow values were also significantly different among sampling months. The greatest mean flow for all sites was in the month of March $(32 \mathrm{~L} / \mathrm{s})$, followed by May, and then July (Table 3-4). This is an expected result, as flows are higher in this region in the spring due to more rainfall and snowmelt (Stewart and Skousen, 2003). However, higher flow values observed in all months, especially the drier months of May and July, may also be due to storm flushes, or large amounts of rain in a short time period. If flow is determined too long after the storm event, the discharge may have returned to its baseline level. As a result of the timing of the sample, a lower flow value would be obtained. Because of this phenomenon, it is very difficult to separate flow due to storm events from flow due to seasonal changes in precipitation.

The lowest variation in flow was generally seen in July, which is when average flows were the lowest (Fig. 3-2, Fig. 3-3, and Table 3-5), and the opposite was found for March with high flows and high variation. This relationship between flow and variation may be typical for the time 
span of a month. Large increases or decreases in variation will have a greater effect on the mean variation when the $\mathrm{n}$ value is small. In this case, the sampling period of a month only gave six or nine water samples each month. Extrapolation of what type of relationship there may be between flow and variation for the time period of a month is difficult to determine without comparing the same months over different years due to annual differences in rainfall and snow melt.

However, this trend was found to proceed in the opposite direction when looking at mean flow and mean variation of all three months, instead of each sampling month. Muddy 11 had the highest average flow over all three sampling months (78 L/s) (Table 3-3), as well as the lowest average variation (21\%) (Table 3-5). Conversely, all sites with lower flows had greater amounts of variation i.e., Fickey 6- $0.3 \mathrm{~L} / \mathrm{s}, 66 \%$ (Table 3-5). This occurred because smaller changes in the independent variables that affected flow had a greater effect on the dependent variable of flow if flow was initially small. This pattern may be more accurate over longer periods of time because more values from more water samples would be available to be averaged together, thus decreasing the variance by increasing the $n$ value. It is possible that this trend may be more readily seen over longer time periods, such as years or decades. More variance may also be observed with discharges that are at the high or low end of the accuracy of the flow measuring device. Flow values from Fickey 6 were near the lower sampling accuracy of the flow meter used for flow measurements in this study.

The data were also analyzed to determine significant differences among mean flow values over the course of a week. Of the eight sampling weeks, the second sampling week in March was found to have the greatest mean flow $(38 \mathrm{~L} / \mathrm{s})$, and the third week of July had the lowest mean flow (5 L/s) (Table 3-6). Similar to the results found when sample months were compared, the weekly means showed a general decreasing trend from March to July. All weeks in March were significantly different from all weeks in July (Table 3-6). Appendix B shows significance matrices for both flow and acidity for all sampling weeks.

In order to further determine how the passage of time changes mine flow, a box-andwhisker plot was constructed. Flow data were plotted comparing 1968, 1980, 2000, and 2006 data for all five sites against March, May, and July 2007 flow data for all five sites. Flow data for the T\&T mine (data from 1996-2006) and the Omega mine (data from 2000-2006) were also plotted as a comparison. Comparing flows from multiple years to those from more intensive, short-term sampling could help to illustrate how time influences the amount of flow from underground mines.

Median flow values were less for all five sites using the short-term data (Fig. 3-4). However, there were fewer samples taken in the long-term data for each site (6) than the short-term data (24). A lower $n$ value would affect the distribution of the points as well as the influence of 
each point on the graph. It is also possible that increased rainfall and snowmelt caused higher median values in the long-term data. Outliers were also found in the long-term data for Green 3 and Fickey 6, as well as the short-term data for Fickey 5, 6, and 7 (Fig. 3-4). It is likely that these points have a greater influence on the overall distribution of the data because they cause the data to be skewed.

Both T\&T and Omega had a smaller data range than the other 5 sites (Fig. 3-4). Flow from both of these sites has remained more consistent over time. However, T\&T has been monitored for 11 years while Omega has data for 7 years. Both mines may begin to show a trend similar to the other five sites as time passes.

\section{Acidity}

Differences among sites $(\mathrm{p}<0.0001)$, sampling month $(\mathrm{p}<0.0001)$, the interaction of sample sites with months $(p<0.0001)$, and sampling weeks within a month $(p<0.0001)$ were all found to be significant for acidity concentrations (Table 3-7).

Acidity values among sites were widely variable over the course of the three-month sampling period (Table 3-1). Green 3 had the highest average acidity for all sites of the threemonth sampling period, while Fickey 6 had the lowest average acidity (Table 3-3). Acidity generally increased over the 3-month time period for all sites (Table 3-4). Acidity was significantly higher in July (524 mg/L) than March and May (342 and 400 mg/L, respectively) (Table 3-4).

Some sites had different patterns in their acidity changes. Four sites showed significant increases in acidity from March to July, but Muddy 11 did not (Table 3-1). July acidities generally had the largest overall variability and the highest values for each site, while March had the second least variability and lowest mean values (Fig. 3-5, Fig. 3-6, and Table 3-8). This trend shows that variability in acidity is tied to how much acidity is present (Fig. 3-5, Fig. 3-6, and Table 3-8).

Similar to flow, median acidity values were less for all five sites in the short-term data (Fig. 3-7). Median acidity concentrations had decreased to a lower level in May 2007 than the first quarter of 2006, which was when the long-term data median values were found. Changes within the mines over the course of a year, especially the limiting of water or oxygen entering the mine, could have affected acidity concentrations. Three outliers were also found in the short-term data for Muddy 11 (Fig. 3-7).

The T\&T and Omega mines had greater median acidities than the other sites, with the exception of Green 3 (Fig. 3-7). However, T\&T and Omega are more likely to be actively oxidizing pyrite because they have not been closed as long as the other mines. The acidity 
concentrations for these two mines will likely continue to change quickly until the initial flush of the mines is complete (Younger, 1997).

Acidity was also found to be significantly different among weeks, but not for weeks within the same month (Table 3-6). In March, mean acidity differed by only $1 \mathrm{mg} / \mathrm{L}$, while in May the range of acidity values was only $12 \mathrm{mg} / \mathrm{L}$. The second week of March had the smallest acidity value $(341 \mathrm{mg} / \mathrm{L})$ while the third week of July had the greatest acidity $(612 \mathrm{mg} / \mathrm{L})$ (Table 3-6).

The study of flow and acidity variation over time is particularly important to the science of passive treatment. Passive treatment systems are designed to handle a specific flow and acid load for a certain amount of time. If either flow or acidity varies too often outside of the specifications to which the passive system was built, the system may not treat the entire discharge to the expected level. By knowing how much variation in flow and acidity to expect over time, resources can be used efficiently and water treatment will be much more effective by allowing for these variations in passive system design and construction.

\section{Flow and acidity}

FA results for all five sites were mostly similar to one another when comparing flow and acidity (Fig 3-8 through 3-12). Flow and acidity consistently showed very different loading values on Factor 1, while these two parameters had similar loading values on Factor 2. The exception was Fickey 6, for which flow ( 0.25 on Factor $1,-0.957$ on Factor 2$)$ and acidity (0.987 on Factor 1, 0.057 on Factor 2) loaded on opposite sides of both Factor 1 and 2. The distances between the lines of these two parameters were widely spaced, meaning that flow and acidity were not strongly related to one another, especially on Factor 1. However, the magnitudes of the lines for each of these parameters were similar, even if the directions were not. Flow was also found to have very little relationship with the other sampled parameters, but was typically most closely related to $\mathrm{pH}$. Sulfate and the sampled cations were often clustered together, perhaps due to similar mineralogy within the mines. The two exceptions to this pattern were Fe loadings for Fickey 5 (Fig. 3-8) and Al loadings for Muddy 11 (Fig. 3-11). Acidity was typically clustered with the sampled cations and anions, particularly $\mathrm{Fe}, \mathrm{Al}$, and $\mathrm{SO}_{4}$. This was expected as these elements make up the bulk of acidity concentrations.

All five sites had less variation in acidity than flow when comparing the mean differences of each sampling month (Tables 3-5 and 3-8). This may be due to the slowing down of pyrite reaction over time. All five sites were closed at least 50 years ago. Changes in the mine environment likely have decreased the amount of oxygen and water entering the mine, as well as decreased the amount of pyrite available for reaction. Because of this, less acidity is produced. 
Flow may also be prone to more variation because of storm events. Flow can change more quickly than acidity concentrations when a large flush of water moves through the mine after a storm.

All the sites also showed similar regression relationships between flow and acidity. Flow was highest in March and lowest in July, while acidity showed the opposite pattern. The slopes of the regression trend lines for all sites were negative, meaning that as flow decreased, acidity increased (Figs. 3-13 through 3-17). $\mathrm{R}^{2}$ values ranged between 0.12 and 0.61 for the five sites, with Green 3 showing the greatest correlation between the two parameters. Sampling of these five discharges would need to occur for several years in order to determine if this trend would continue over a longer period of time.

These results agree with the "high concentrations at low flows" theory proposed by Skousen and Ziemkiewicz (1996). The "high concentrations at low flows" theory states that there is less water to dilute acidity concentrations at low flows. Similar results were found by Stillings (2007) at the Beatson mine in Alaska and Griffiths et al. (2001) at the Arnot mine in Pennsylvania.

Other researchers have found that chemistry changes with flow. Smith (1988) described three different types of discharges: (1) high flow/low concentration discharges in which the flow rate varies inversely with the acidity concentrations, (2) steady rate discharges in which moderate changes in flow rate produce moderate changes in concentrations, and (3) "Slugger response," in which large increases in flow give very little change in concentrations. All five sites studied in this thesis fit the description of type 1 discharges. Alpers et al. (1992) found that $\mathrm{Cu}$ and $\mathrm{Zn}$ concentrations rose with increases in discharge due to storm events at the Iron Mountain mine in California. The largest increases occurred in November 1987 at the beginning of the winter wet season (Fig. 3-18). In his study of the Contrary Creek watershed in Virginia, Dagenhart (1980) found that there were marked increases in certain metal concentrations during the initial increasing of the flow values from a single storm event (Fig 3-19). Metals that formed efflorescent salts, such as Fe, had a much larger concentration increase than did those metals that did not form efflorescent salts, such as Mn.

Both the Alpers et al. and Dagenhart study contradicted the results found in this thesis. Both studies showed increasing concentrations with increased flow. However, Alpers' research was performed in the western United States, which has a different climate than the Mid-Atlantic region. Rain storms are typically more intense and less frequent. Both studies also researched metal mines, not coal mines. The geochemistry of a metal mine can be vastly different from that of a coal mine due to differences in overburden and mineral types found in the mine. However, these studies give insight into the basic nature of the relationship between changes in flow and water chemistry. 


\section{Conclusions}

Five above-drainage underground mines showed wide variations in flow and slightly lower variations in acidity across three weeks in 2007 . Weeks within the same month were usually found to not vary significantly for flow. There was an average change in flows of $63 \%$ over a month, and an average change of $53 \%$ over the time span of a week.

An inverse relationship between flow and amount of variation within each sampling month was established. Fickey 6 had the least flow and the greatest variation, while Muddy 11 showed the opposite relationship.

In terms of acidity, each grouping of water sample sites, months, and weeks were all found to be significantly different from one another. Acidity concentrations for March and May were significantly different from those in July. Acidity also varied for weeks across months, but not within months. Similar to flow, there was a greater mean change in acidity over a month than a week.

A positive relationship between acidity and amount of variation within each sampling month was observed. Sites with lower acidity concentrations also had lower variation in acidity over time.

\section{$\underline{\text { Literature Cited }}$}

Alpers, C.N., Nordstrom, D.K., and Burchard, J.M. 1992. Compilation and interpretation of waterquality and discharge data for acidic mine waters at Iron Mountain, Shasta County, California, 1949-91. U.S. Geological Survey Water-Resources Investigations Report 91-4160, 173 pp.

Borek S. L., Ackman, T.E., Watzlaf, G. P., Hammack, R.W., and Lipscomb, J.P. 1991. The longterm evaluation of mine seals constructed in Randolph County, WV in 1967. In Proceedings of the $12^{\text {th }}$ Annual West Virginia Surface Mine Drainage Task Force Symposium, April 3-4, 1991, Morgantown, W.V.

Buchanan, T.J. and Somers, W. P. 1976. Discharge measurements at gauging stations. Chap. A8, p. 32-33 In Techniques of Water-Resources Investigations of the United States Geological Survey, Book 3; Application of Hydraulics. USGS, Washington D.C.

Dagenhart, T.V., Jr. 1980. The acid mine drainage of Contrary Creek, Louisa County, Virginia. M.S. thesis, University of Virginia, Charlottesville, Virginia, $215 \mathrm{pp}$.

Demchak, J, Skousen, J., and McDonald, L.M. 2004. Longevity of acid discharges from underground mines located above the regional water table. Journal of Environmental Quality 33: 656-658. 
Desbarats, A.J., and Dirom, G.C. 2007. Temporal variations in the chemistry of circum-neutral drainage from the 10-Level portal, Myra Mine, Vancouver Island, British Columbia. Applied Geochemistry 22 (2): 415-435.

Griffiths, J.C., Hornberger, R.J., Miller, K., and Smith, M.W. 2001. Statistical analysis of abandoned mine drainage in the assessment of pollution load ("The Griffiths Report"). EPA- 821B-01-014. 268 p. National Technical Information Service \# PB2002-104395, Springfield, VA.

Kirby, C.S., and Cravotta III, C.A. 2004. Net Alkalinity and net acidity 1: Theoretical considerations. Applied Geochemistry 20: 1920-1940.

Lopez D.L. and Stoertz, M.W. 2001. Chemical and physical controls on water discharged from abandoned coal mines. Geochemistry: Exploration, Environment, Analysis 1: 51-60.

McDonough, K., Lambert, D.C., Mugunthan, P., and Dzombak, D.A. 2005. Processes governing flow and chemical characteristics of discharges from free-draining, underground coal mines. Journal of Environmental Engineering 131 (10): 1361-1368.

Pigati, E., and Lopez, D. 1999. Effect of subsidence on recharge at abandoned coal mines generating acidic drainage: the Majestic mine, Athens County, OH. Mine Water and the Environment 18 (1): 45-66.

Skousen, J., and Ziemkiewicz, P. 1996. Acid mine drainage control and treatment. National Research Center for Coal and Energy, West Virginia University, Morgantown, WV.

Smith, M.W., 1988. Establishing baseline pollution load from preexisting pollutional discharges for remining in Pennsylvania. US Bureau of Mines IC 9184, pp. 311-318.

Stewart, J., and Skousen, J. 2003. Water quality changes in a polluted stream over a twenty-five year period. J. Environ. Qual. 32(2): 654-661.

Stillings, L.L., Foster, A.L., Koski, R., Munk, L., and Shanks, W.C. 2006. The effect of discharge on water quality and $\mathrm{Cu}$ flux from the Beatson mine site, Prince William Sound, AK. In Geological Society of America Abstracts with Programs 38 (7): 432.

Wendland, W.M. 2001. Temporal responses of surface water and groundwater to precipitation in Illinois. J. Am. Water Res. Assoc. 37: 685-693.

Younger, P. L. 1997. The longevity of minewater pollution: a basis for decision-making. The Science of the Total Environment 194-195: 457-466. 
Table 3-1. Descriptive statistics for flow and acidity.

\begin{tabular}{|c|c|c|c|c|c|c|c|}
\hline & & \multicolumn{3}{|c|}{ Flow } & \multicolumn{3}{|c|}{ Acidity } \\
\hline & & \multicolumn{3}{|c|}{ (L/s) } & \multicolumn{3}{|c|}{ (mg/L as $\mathrm{CaCO} 3)$} \\
\hline Site & $\begin{array}{l}\text { Sample } \\
\text { month }\end{array}$ & mean & $\mathrm{n}$ & St. Dev. & mean & $\mathbf{n}$ & St. Dev. \\
\hline \multirow[t]{3}{*}{ Fickey 5} & March & $22 a$ & 6 & 11.3 & $329 b$ & 6 & 37.8 \\
\hline & May & $9 b$ & 9 & 3.7 & $335 b$ & 9 & 52.4 \\
\hline & July & $1 c$ & 9 & 0.2 & $516 a$ & 9 & 113.6 \\
\hline \multirow[t]{3}{*}{ Fickey 6} & March & $0.6 a$ & 6 & 0.4 & $49 b$ & 6 & 9.7 \\
\hline & May & $0.2 b$ & 9 & 0.2 & $59 b$ & 9 & 4.8 \\
\hline & July & $0.05 c$ & 9 & 0.04 & $89 a$ & 9 & 8.7 \\
\hline \multirow[t]{3}{*}{ Fickey 7} & March & $9 a$ & 6 & 9.6 & $311 b$ & 6 & 19.6 \\
\hline & May & $2 b$ & 9 & 0.5 & $342 b$ & 9 & 33.9 \\
\hline & July & $0.7 b$ & 9 & 0.7 & $510 a$ & 9 & 87.7 \\
\hline \multirow[t]{3}{*}{ Muddy 11} & March & $127 a$ & 6 & 42.4 & $359 a$ & 6 & 47.6 \\
\hline & May & $79 b$ & 9 & 23.4 & $341 a$ & 9 & 13.0 \\
\hline & July & $29 b$ & 9 & 3.9 & $409 a$ & 9 & 58.9 \\
\hline \multirow[t]{3}{*}{ Green 3} & March & $1 a$ & 6 & 0.3 & $663 b$ & 6 & 92.0 \\
\hline & May & $0.1 b$ & 9 & 0.06 & $924 a$ & 9 & 28.6 \\
\hline & July & $0.03 b$ & 9 & 0.002 & $1094 a$ & 9 & 178.0 \\
\hline
\end{tabular}

Table 3-2. Analysis of variance results for flow of five sites.

\begin{tabular}{cccc}
\hline Model & $\mathbf{n}$ & DF & P value \\
\hline Sample site & 5 & 4 & $<0.0001$ \\
Month & 3 & 2 & $<0.0001$ \\
Sample site *month & 15 & 8 & $<0.0001$ \\
Week (month) & 8 & 5 & 0.007 \\
\hline
\end{tabular}


Table 3-3. Mean flow and acidity values for entire sampling period by site.

\begin{tabular}{cccc}
\hline Site & n & $\begin{array}{c}\text { Mean flow } \\
\text { for } \\
\text { all months } \\
\text { (L/s) }\end{array}$ & $\begin{array}{c}\text { Mean acidity } \\
\text { for } \\
\text { all months } \\
(\mathbf{m g} / \mathbf{L ~} \text { as } \\
\text { CaCO3) }\end{array}$ \\
\hline Fickey 5 & 3 & $11 \mathrm{~b}$ & $393 \mathrm{~b}$ \\
Fickey 6 & 3 & $0.3 \mathrm{c}$ & $65 \mathrm{c}$ \\
Fickey 7 & 3 & $4 \mathrm{bc}$ & $388 \mathrm{~b}$ \\
Muddy 11 & 3 & $78 \mathrm{a}$ & $370 \mathrm{~b}$ \\
Green 3 & 3 & $0.4 \mathrm{c}$ & $894 \mathrm{a}$ \\
\hline
\end{tabular}

Table 3-4. Mean flow and acidity values for each sampling month.

\begin{tabular}{cccc}
\hline Month & $\mathbf{n}$ & $\begin{array}{c}\text { Mean } \\
\text { flow }\end{array}$ & Mean acidity \\
\hline & & $(\mathbf{L} / \mathbf{s})$ & $\mathbf{( m g / L ~ a s ~ C a C O 3 )}$ \\
\hline March & 30 & $32 \mathrm{a}$ & $342 \mathrm{~b}$ \\
May & 45 & $18 \mathrm{~b}$ & $400 \mathrm{~b}$ \\
July & 45 & $6 \mathrm{c}$ & $524 \mathrm{a}$ \\
\hline
\end{tabular}


Table 3-5. Percent difference of mean flow values for five sites.

\begin{tabular}{|c|c|c|c|c|c|c|c|}
\hline Month & Site & $\mathbf{n}$ & $\begin{array}{c}\text { Mean } \\
\text { flow } \\
\text { (L/s) }\end{array}$ & $\begin{array}{l}\text { Range of } \\
\text { flow (L/s) }\end{array}$ & $\begin{array}{c}\text { Mean } \\
\text { difference } \\
\text { within site for } \\
\text { each month } \\
(\%)\end{array}$ & $\begin{array}{c}\text { Mean } \\
\text { difference } \\
\text { within a site } \\
\text { over three } \\
\text { months } \\
(\%)\end{array}$ & $\begin{array}{c}\text { Mean } \\
\text { difference } \\
\text { for each } \\
\text { month } \\
(\%)\end{array}$ \\
\hline \multirow[t]{5}{*}{ March } & Fickey 5 & 6 & 22 & $8-43$ & 33 & 23 & 42 \\
\hline & Fickey 6 & 6 & 1 & $0.06-1$ & 52 & 66 & \\
\hline & Fickey 7 & 6 & 9 & $4-28$ & 72 & 50 & \\
\hline & Muddy 11 & 6 & 127 & $76-180$ & 28 & 21 & \\
\hline & Green 3 & 6 & 1 & $0.7-1$ & 24 & 24 & \\
\hline \multirow[t]{5}{*}{ May } & Fickey 5 & 9 & 9 & $4-17$ & 25 & & 38 \\
\hline & Fickey 6 & 9 & 0.3 & $0.01-0.6$ & 77 & & \\
\hline & Fickey 7 & 9 & 2 & $1-3$ & 20 & & \\
\hline & Muddy 11 & 9 & 79 & $38-106$ & 25 & & \\
\hline & Green 3 & 9 & 0.1 & $0.06-0.3$ & 43 & & \\
\hline \multirow[t]{5}{*}{ July } & Fickey 5 & 9 & 1 & $1-2$ & 12 & & 31 \\
\hline & Fickey 6 & 9 & 0.05 & $0.01-0.1$ & 69 & & \\
\hline & Fickey 7 & 9 & 1 & $0.4-3$ & 58 & & \\
\hline & Muddy 11 & 9 & 29 & $22-36$ & 10 & & \\
\hline & Green 3 & 9 & 0.03 & $0.03-0.03$ & 6 & & \\
\hline
\end{tabular}

Table 3-6. Flow and acidity values for each week. All flow and acidity values are mean values.

\begin{tabular}{cccc}
\hline Week & n & Mean flow & Mean acidity \\
\hline & & $(\mathbf{L} / \mathbf{s})$ & $(\mathbf{m g} / \mathbf{L}$ as CaCO3) \\
\hline March, \#1 & 15 & $26 \mathrm{~b}$ & $342 \mathrm{c}$ \\
March, \#2 & 15 & $38 \mathrm{a}$ & $341 \mathrm{c}$ \\
May, \#1 & 15 & $22 \mathrm{~b}$ & $401 \mathrm{bc}$ \\
May, \#2 & 15 & $21 \mathrm{~b}$ & $394 \mathrm{bc}$ \\
May, \#3 & 15 & $11 \mathrm{c}$ & $406 \mathrm{~b}$ \\
July, \#1 & 15 & $7 \mathrm{c}$ & $441 \mathrm{~b}$ \\
July, \#2 & 15 & $7 \mathrm{c}$ & $518 \mathrm{a}$ \\
July, \#3 & 15 & $5 \mathrm{c}$ & $612 \mathrm{a}$ \\
\hline
\end{tabular}


Table 3-7. Analysis of variance results for acidity of five sites.

\begin{tabular}{ccccc}
\hline Model & DF & P value & Alpha & Significance \\
\hline Sample site & 4 & $<0.0001$ & 0.05 & $\mathrm{Y}$ \\
Month & 2 & $<0.0001$ & & $\mathrm{Y}$ \\
Sample site *${ }^{\text {month }}$ & 8 & $<0.0001$ & & $\mathrm{Y}$ \\
Week & 5 & $<0.0001$ & & $\mathrm{Y}$ \\
\hline
\end{tabular}

Table 3-8. Percent difference of mean acidity values for five sites.

\begin{tabular}{|c|c|c|c|c|c|c|c|}
\hline Month & Site & $\mathbf{n}$ & $\begin{array}{c}\text { Mean acidity } \\
\text { (mg/L } \\
\text { as } \mathrm{CaCO})\end{array}$ & $\begin{array}{c}\text { Range } \\
\text { of acidity } \\
\text { (mg/L as } \\
\text { CaCO3) }\end{array}$ & $\begin{array}{c}\text { Mean difference } \\
\text { within site for } \\
\text { each month } \\
(\%)\end{array}$ & $\begin{array}{c}\text { Mean } \\
\text { difference } \\
\text { within a } \\
\text { site over } \\
\text { three } \\
\text { months } \\
(\%)\end{array}$ & $\begin{array}{l}\text { Mean } \\
\text { difference } \\
\text { for each } \\
\text { month for } \\
\text { all sites } \\
(\%)\end{array}$ \\
\hline \multirow[t]{5}{*}{ March } & Fickey 5 & 6 & 329 & $284-370$ & 9 & 13 & 10 \\
\hline & Fickey 6 & 6 & 48 & $31-56$ & 15 & 10 & \\
\hline & Fickey 7 & 6 & 311 & $276-330$ & 4 & 9 & \\
\hline & Muddy 11 & 6 & 359 & $312-444$ & 9 & 9 & \\
\hline & Green 3 & 6 & 663 & $500-761$ & 10 & 8 & \\
\hline \multirow[t]{5}{*}{ May } & Fickey 5 & 9 & 335 & $297-467$ & 10 & & 6 \\
\hline & Fickey 6 & 9 & 58 & $53-65$ & 6 & & \\
\hline & Fickey 7 & 9 & 342 & 298-398 & 8 & & \\
\hline & Muddy 11 & 9 & 341 & $323-367$ & 3 & & \\
\hline & Green 3 & 9 & 924 & $859-954$ & 2 & & \\
\hline \multirow[t]{5}{*}{ July } & Fickey 5 & 9 & 516 & $374-635$ & 20 & & 14 \\
\hline & Fickey 6 & 9 & 89 & $75-102$ & 8 & & \\
\hline & Fickey 7 & 9 & 510 & $379-634$ & 15 & & \\
\hline & Muddy 11 & 9 & 409 & $343-488$ & 13 & & \\
\hline & Green 3 & 9 & 1094 & $805-1318$ & 13 & & \\
\hline
\end{tabular}




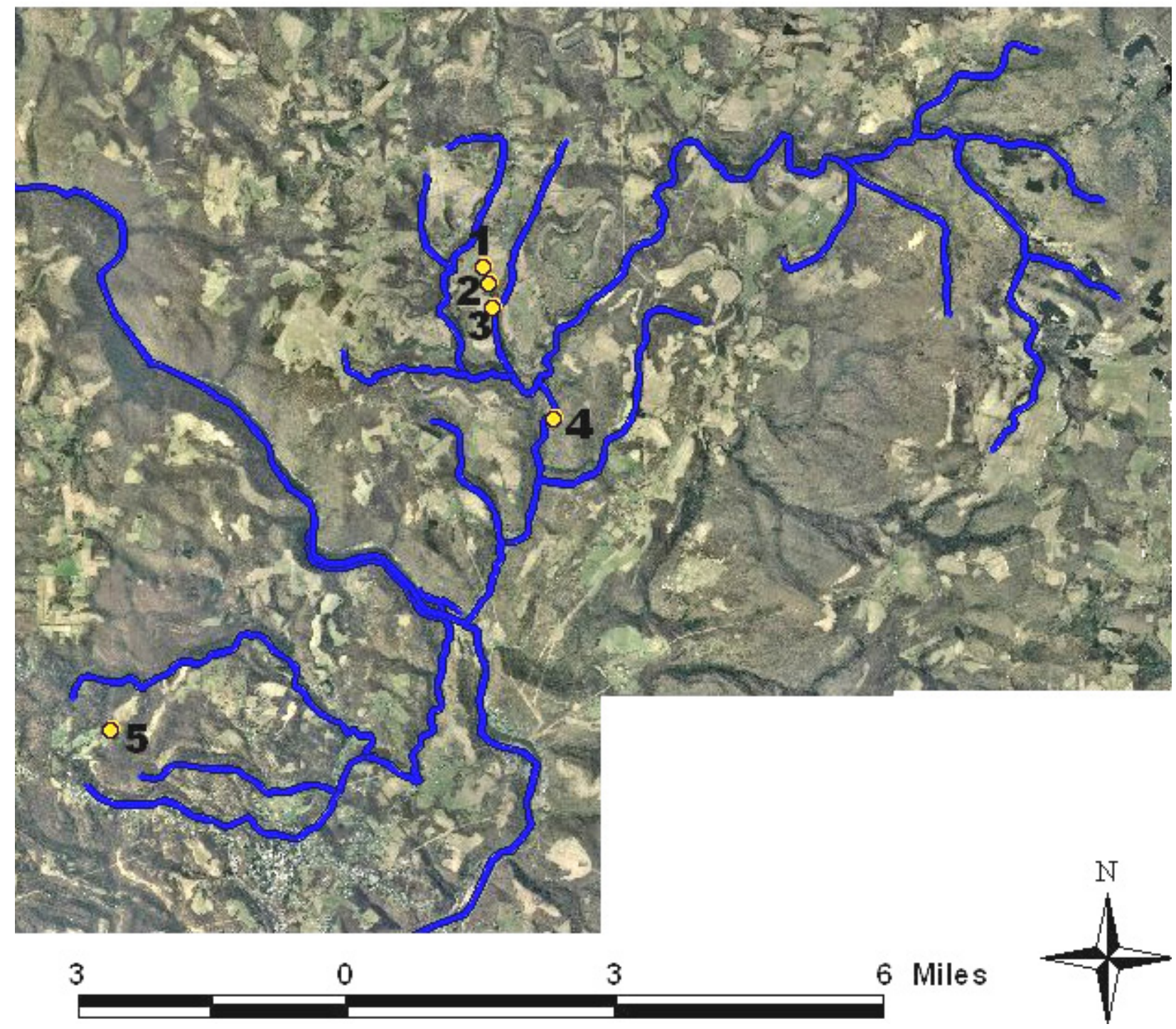

Fig. 3-1. Map of five intensively sampled sites represented by the orange dots. Site 1= Fickey 5, Site 2=Fickey 6, Site 3=Fickey 7, Site 4= Muddy 11, and Site 5=Green 3. Sites 1-4 are in the Muddy Creek subwatershed and site 5 is in the Greens Run subwatershed. 

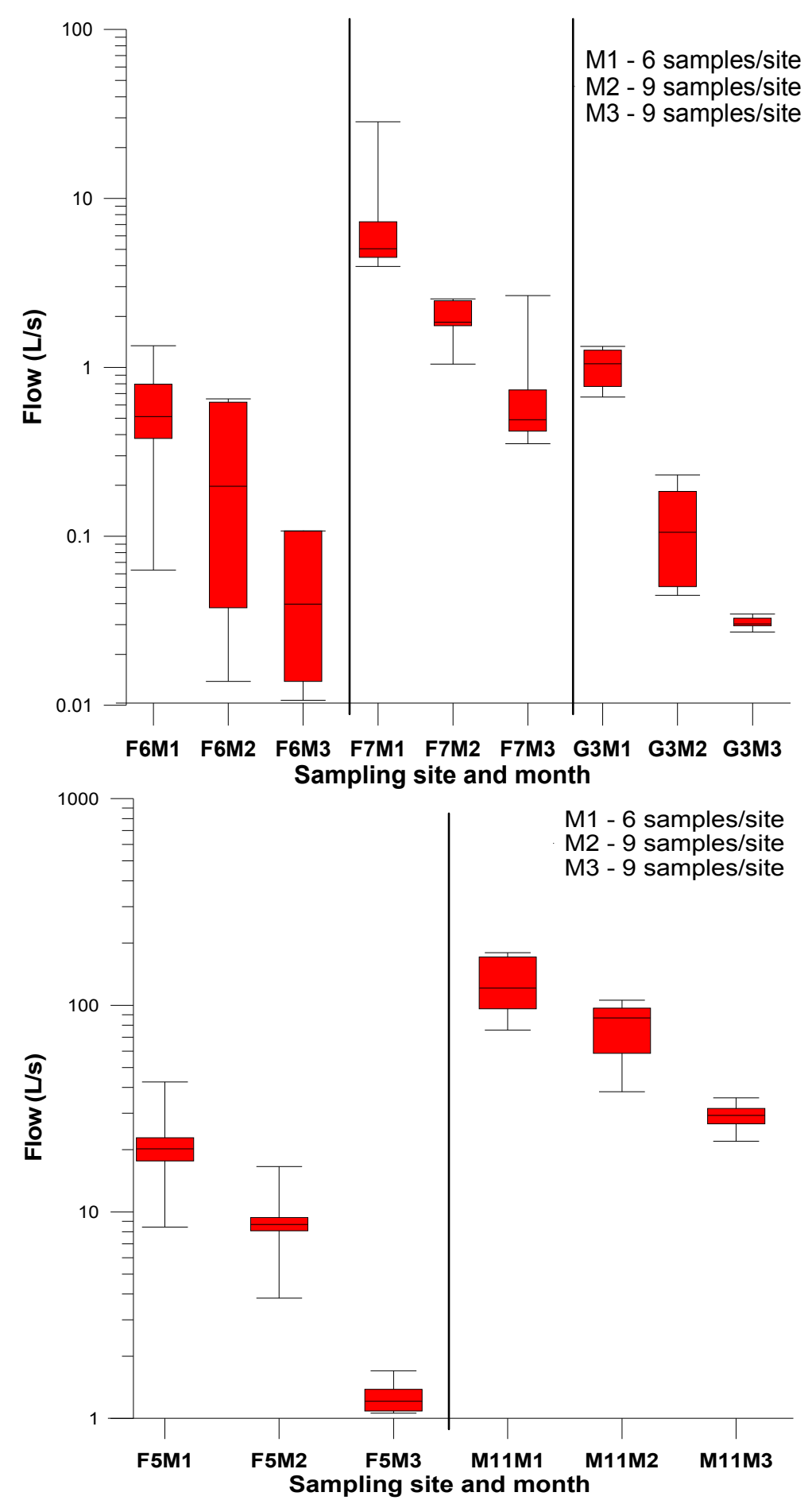

Fig 3-2. Range of flow for each sampling site and month. Each box represents the mid-range of the data while the black line in the middle of each box is the median. The lines extending from the box terminate at the minimum and maximum value of the data. M1=March, M2=May, and M3=July. F5, F6, and F7= Fickey 5, 6, and 7, M11= Muddy 11, and G3=Green 3. Fickey 5 and Muddy 11 were graphed separately to keep the graphs legible. 


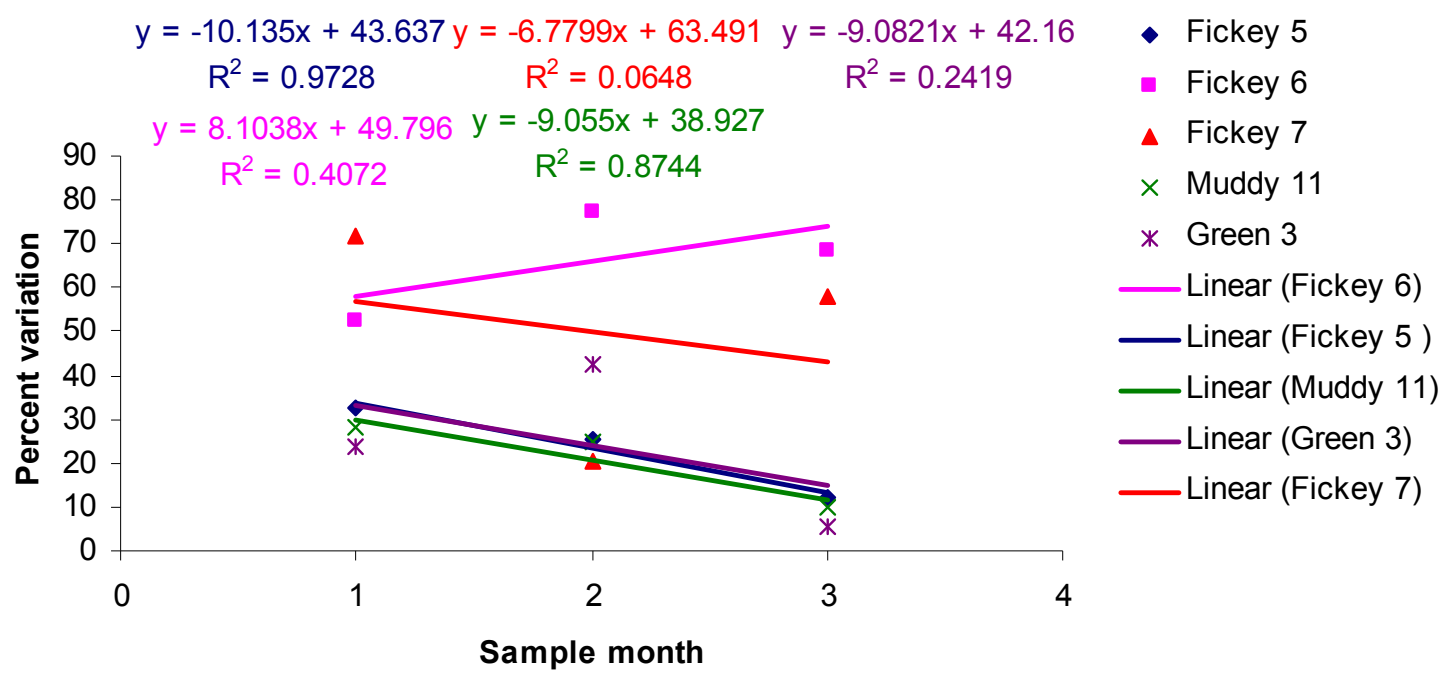

Fig. 3-3. Relationship between percent variation and sample month for flow. All sites except Fickey 6 show an inverse relationship between the two parameters. Month 1=March, Month 2=May, and Month 3=July.

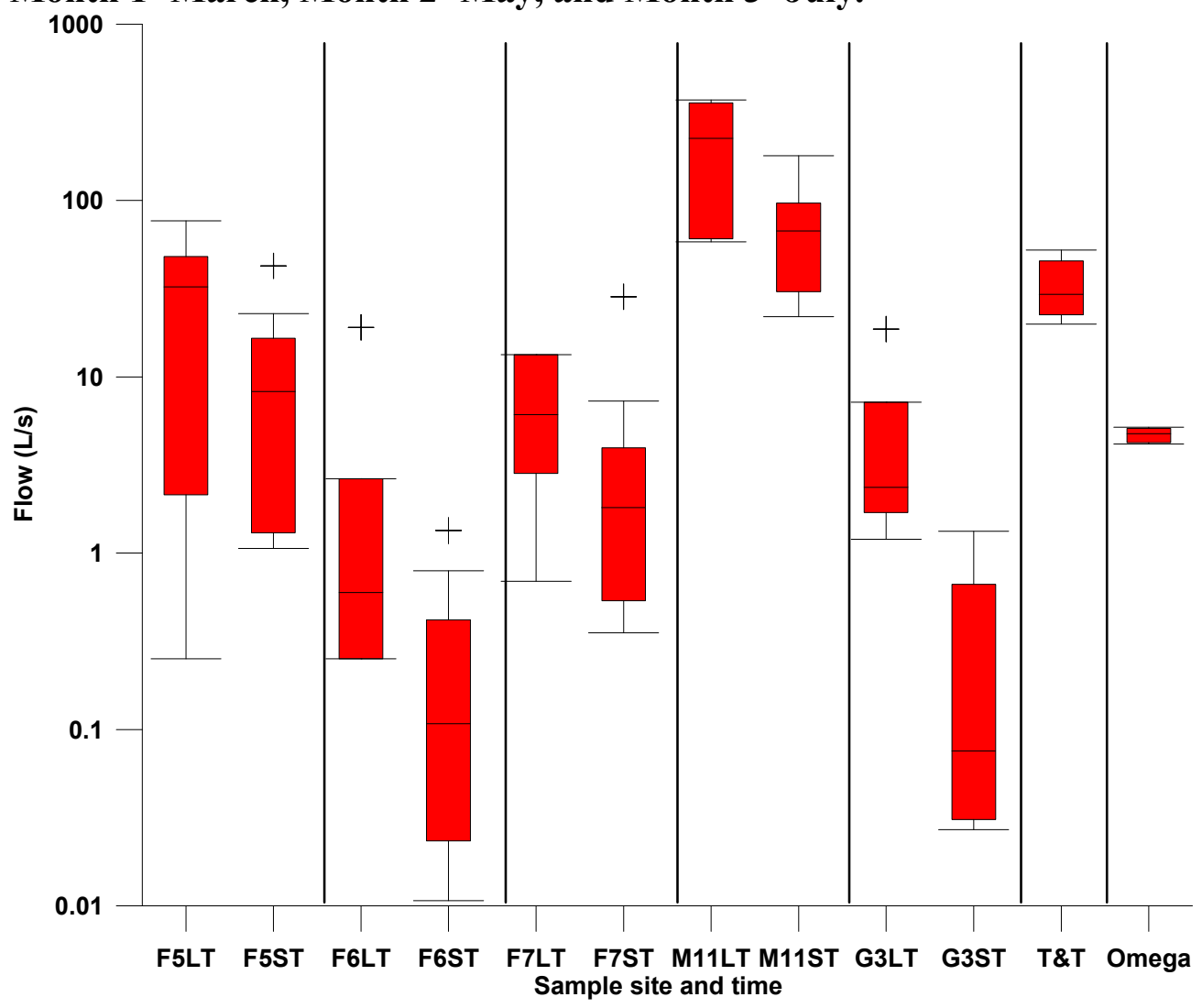

Fig. 3-4. Comparison of long-term and short-term flow values. Each box represents the mid-range of the data while the black line in the middle of each box is the median. The lines extending from the box terminate at the minimum and maximum value of the data. F5, F6, and F7= Fickey 5, 6, and 7, M11= Muddy 11, and G3=Green 3. LT=Long-term, ST=Short-term. " "+"=outlier. 


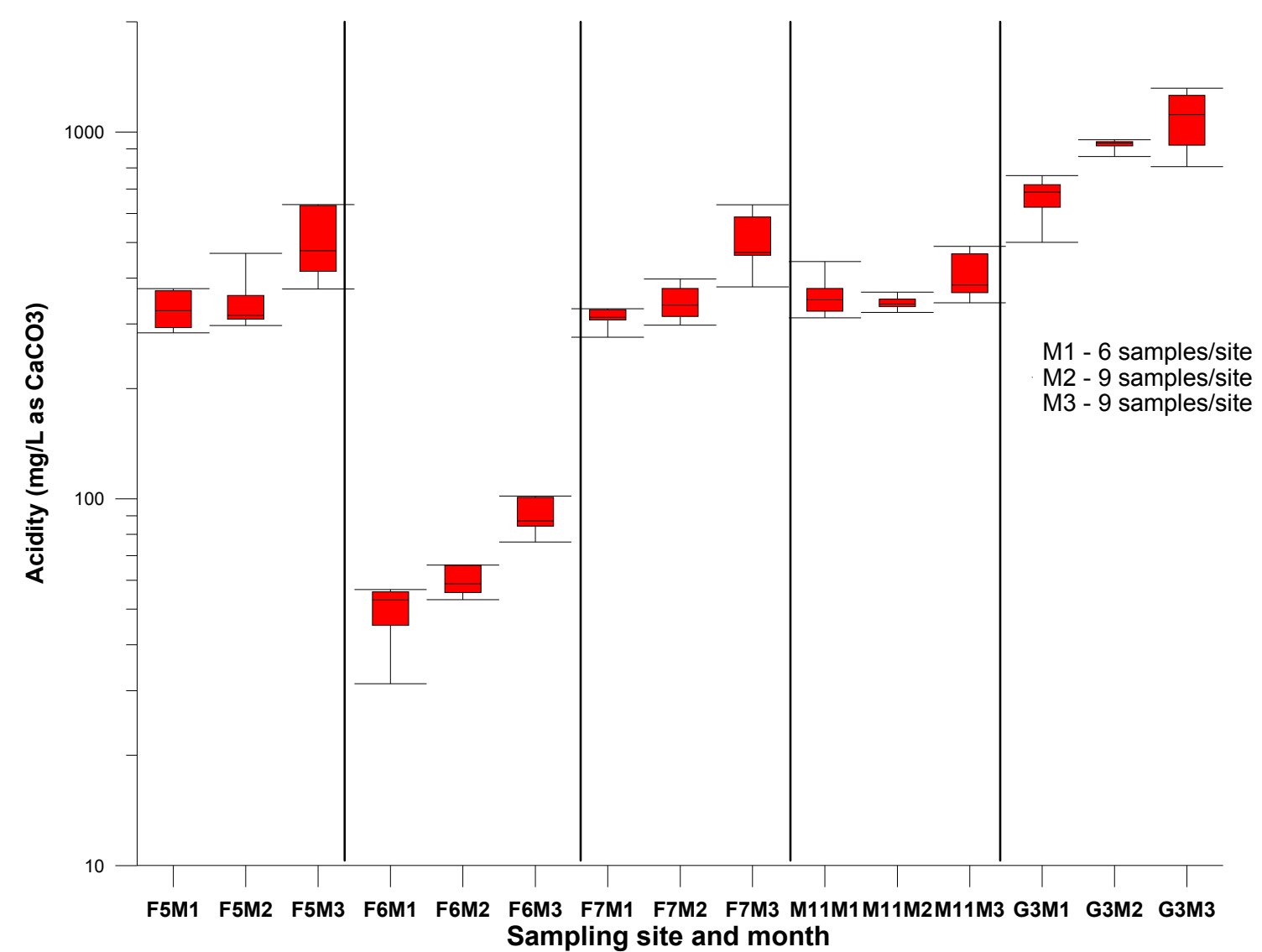

Fig. 3-5. Range of acidity for each sampling site and month. Each box represents the mid-range of the data while the black line in the middle of each box is the median. The lines extending from the box terminate at the minimum and maximum value of the data. M1=March, M2=May, and M3=July. F5, F6, and F7 = Fickey 5, 6, and 7, M11 $=$ Muddy 11, and G3=Green 3.

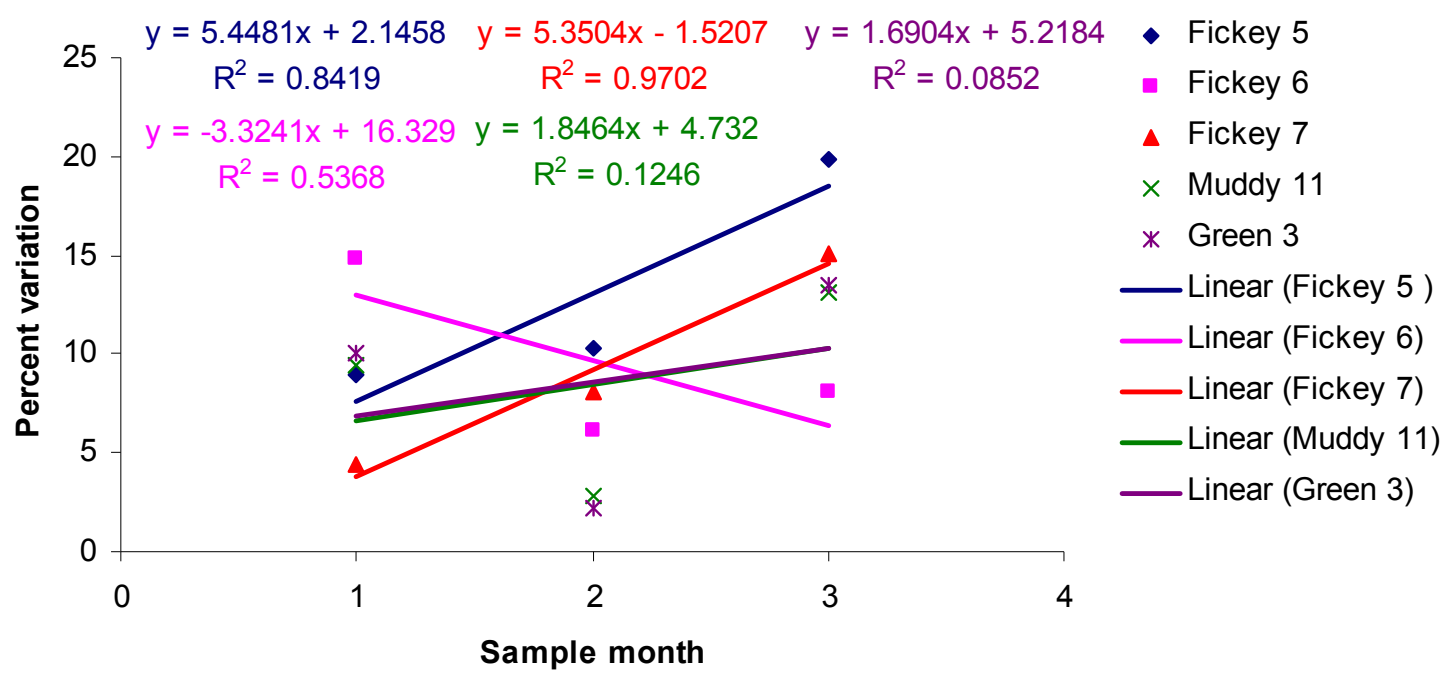

Fig. 3-6. Percent variation of acidity vs. sample month. All sites except Fickey 6 show a positive relationship between the two parameters. Month $1=$ March, Month 2=May, and Month 3=July. 


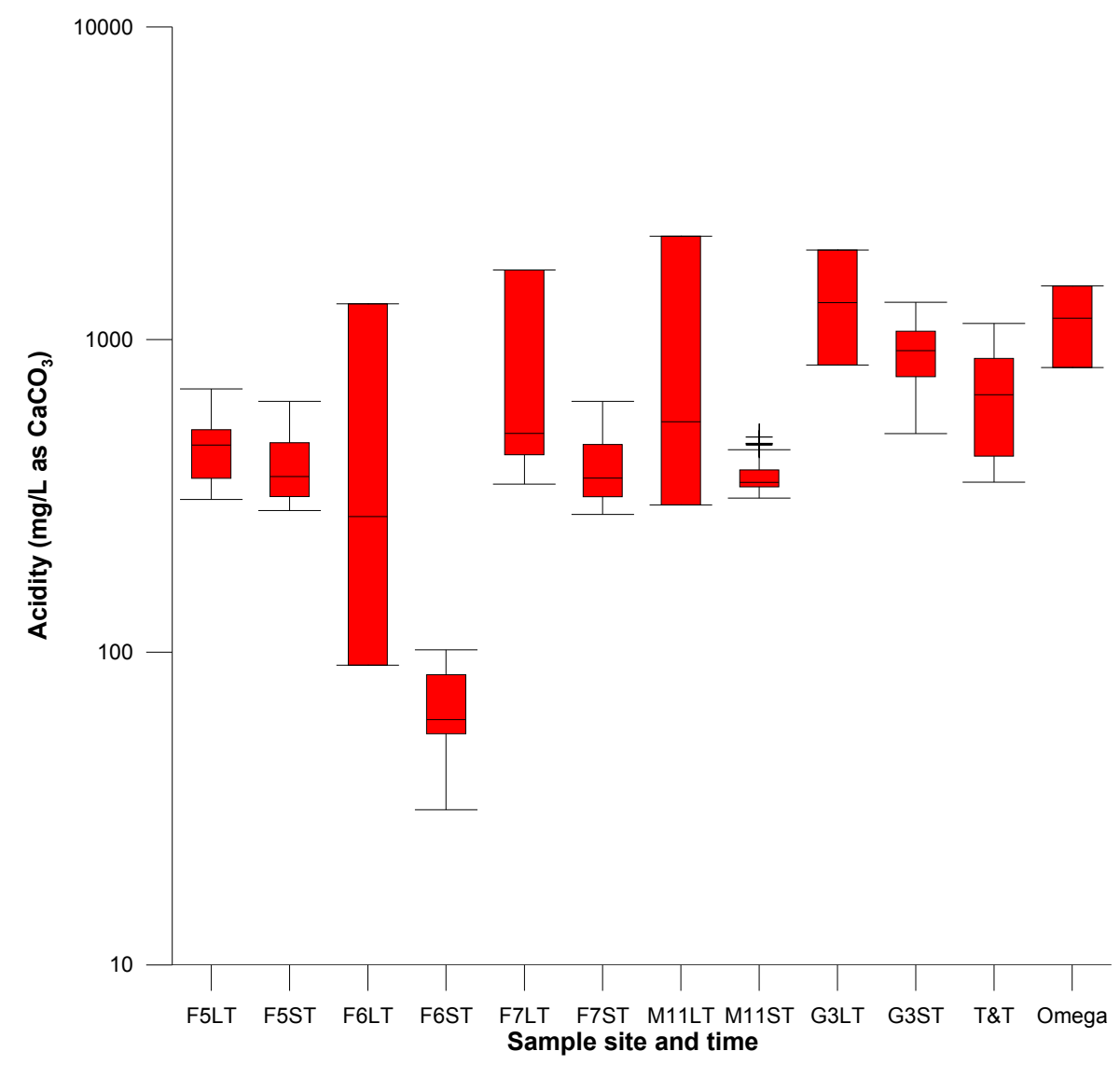

Fig. 3-7. Comparison of long-term and short-term acidity values. Each box represents the mid-range of the data while the black line in the middle of each box is the median. The lines extending from the box terminate at the minimum and maximum value of the data. F5, F6, and F7= Fickey 5, 6, and 7, M11= Muddy 11, and G3=Green 3. LT=Long-term, ST=Short-term. " "+" =outlier. 


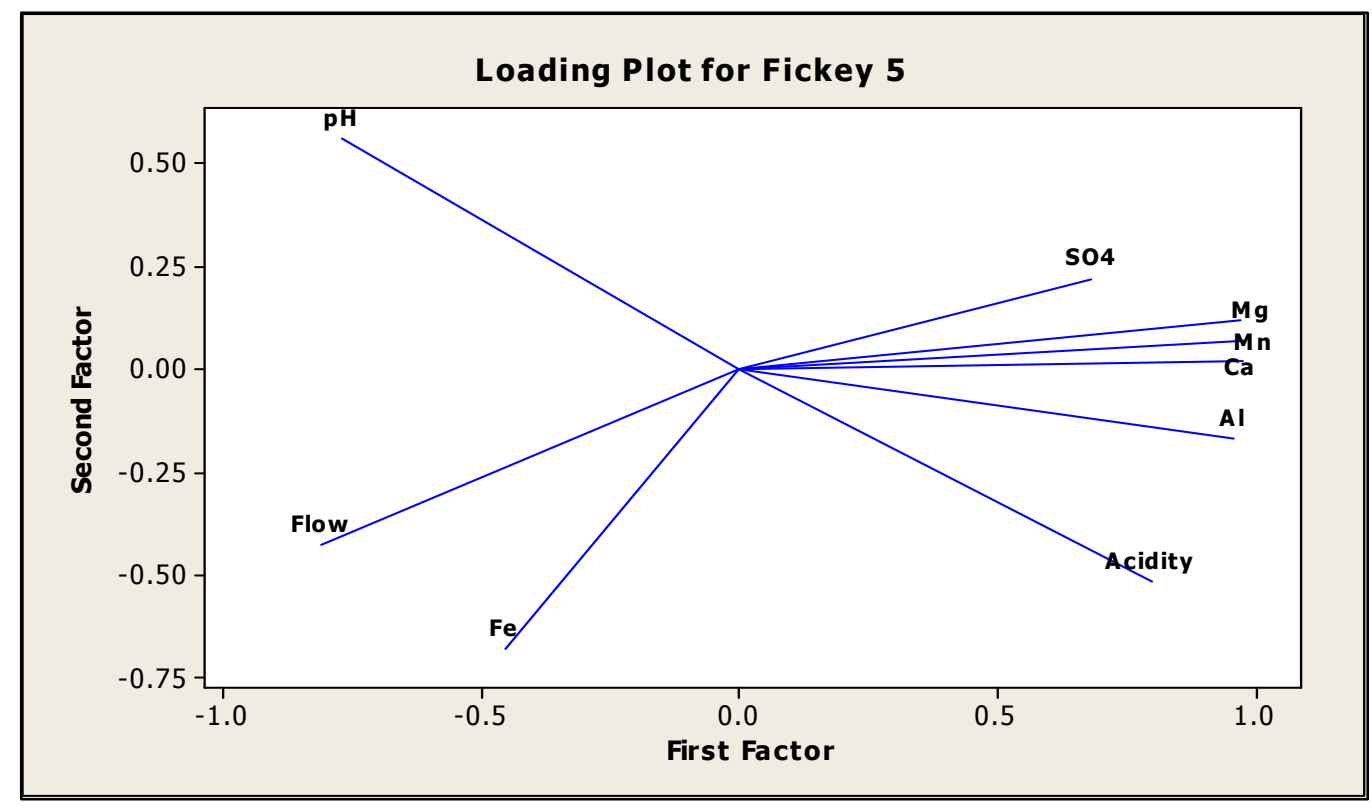

Fig. 3-8. FA results for Fickey 5. Direction of lines indicates the loading of a parameter on the first or factor. Length of the lines indicates parameter magnitude. Acidity and flow show an opposite relationship to one another, as do $\mathrm{pH}$ and acidity.

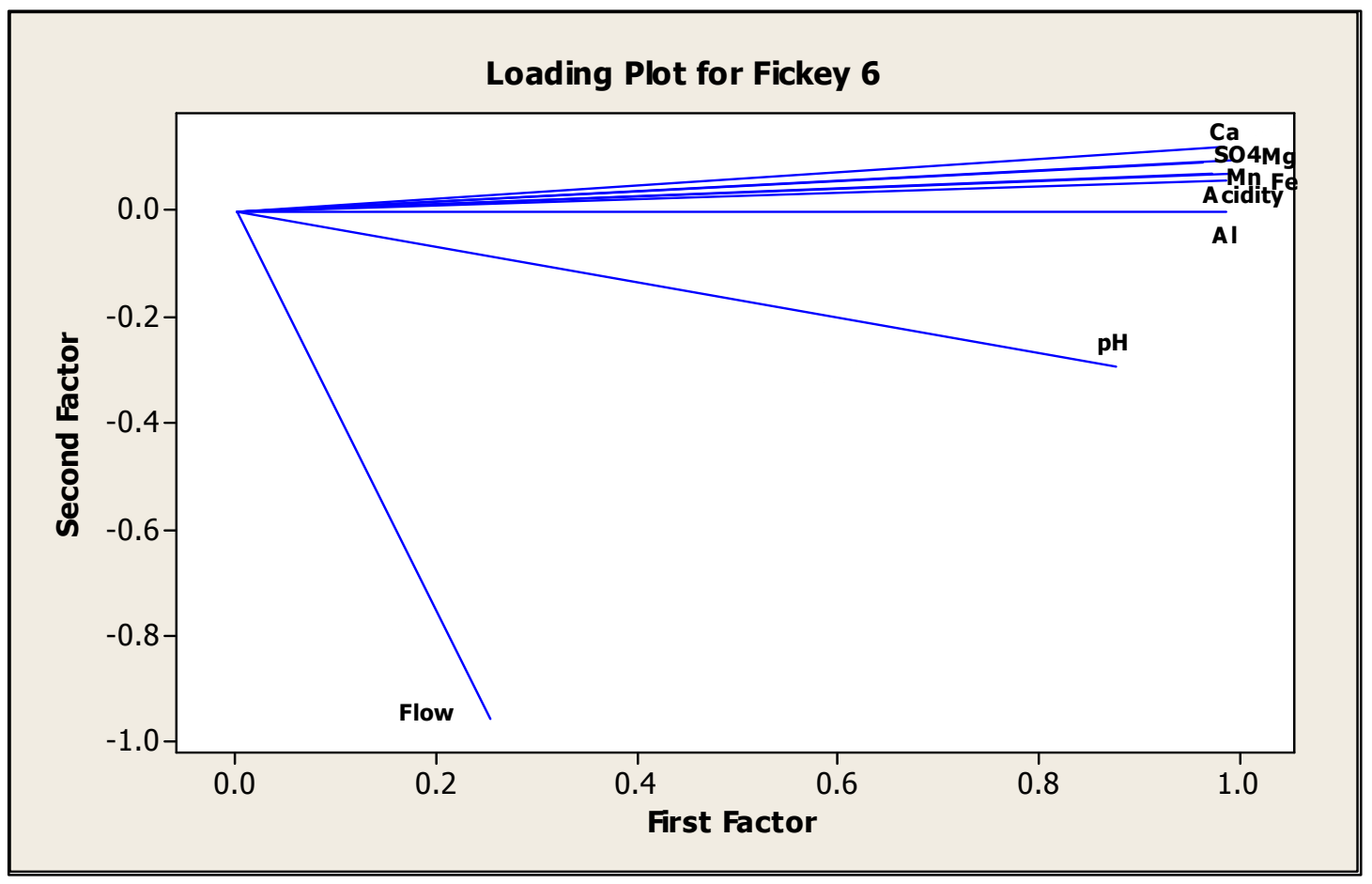

Fig. 3-9. FA results for Fickey 6. Direction of lines indicates the loading of a parameter on the first or second component. Length of the lines indicates parameter magnitude. Acidity and flow show an opposite relationship to one another, as do pH and acidity. 


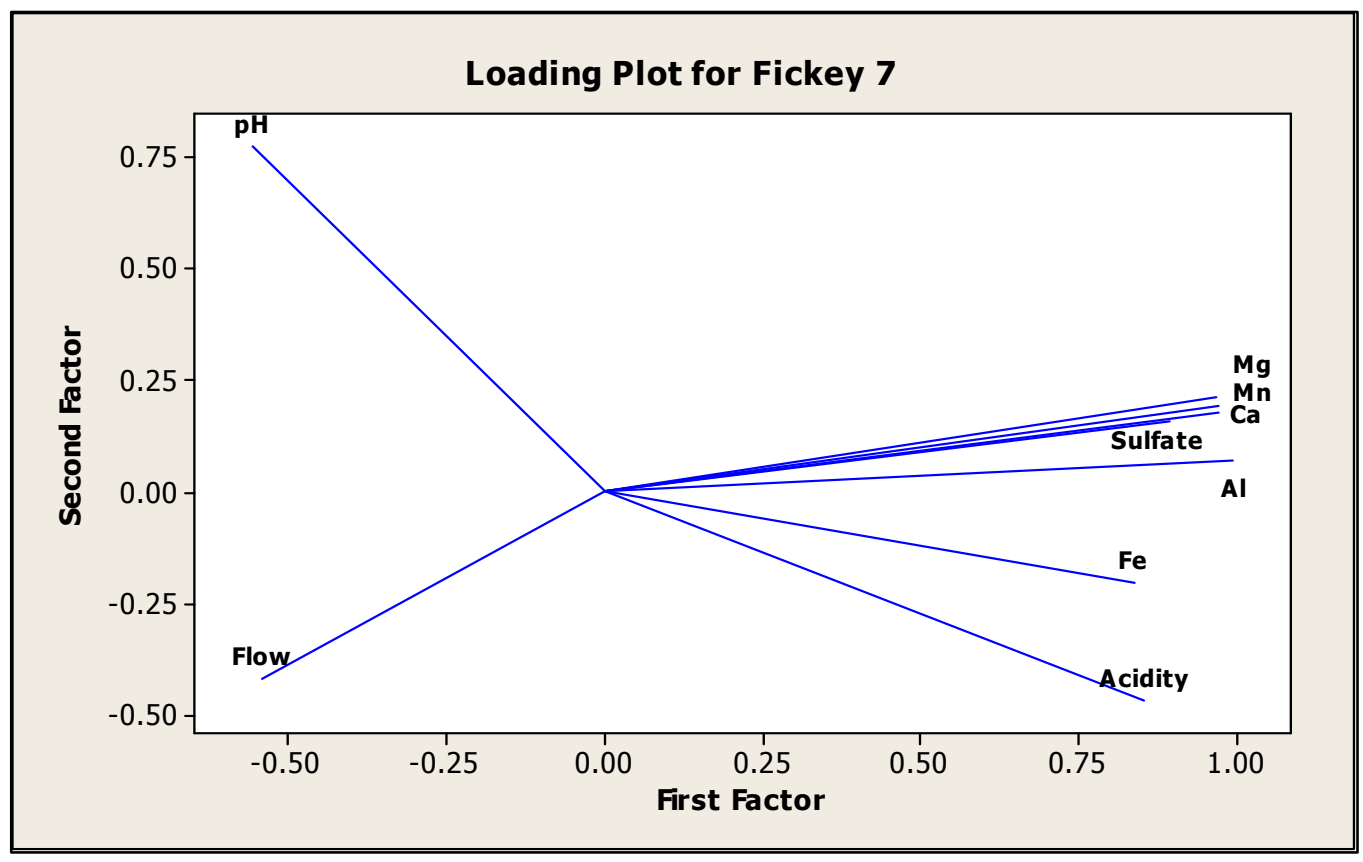

Fig 3-10. FA results for Fickey 7. Direction of lines indicates the loading of a parameter on the first or second component. Length of the lines indicates parameter magnitude. Acidity and flow show an opposite relationship to one another, as do pH and acidity.

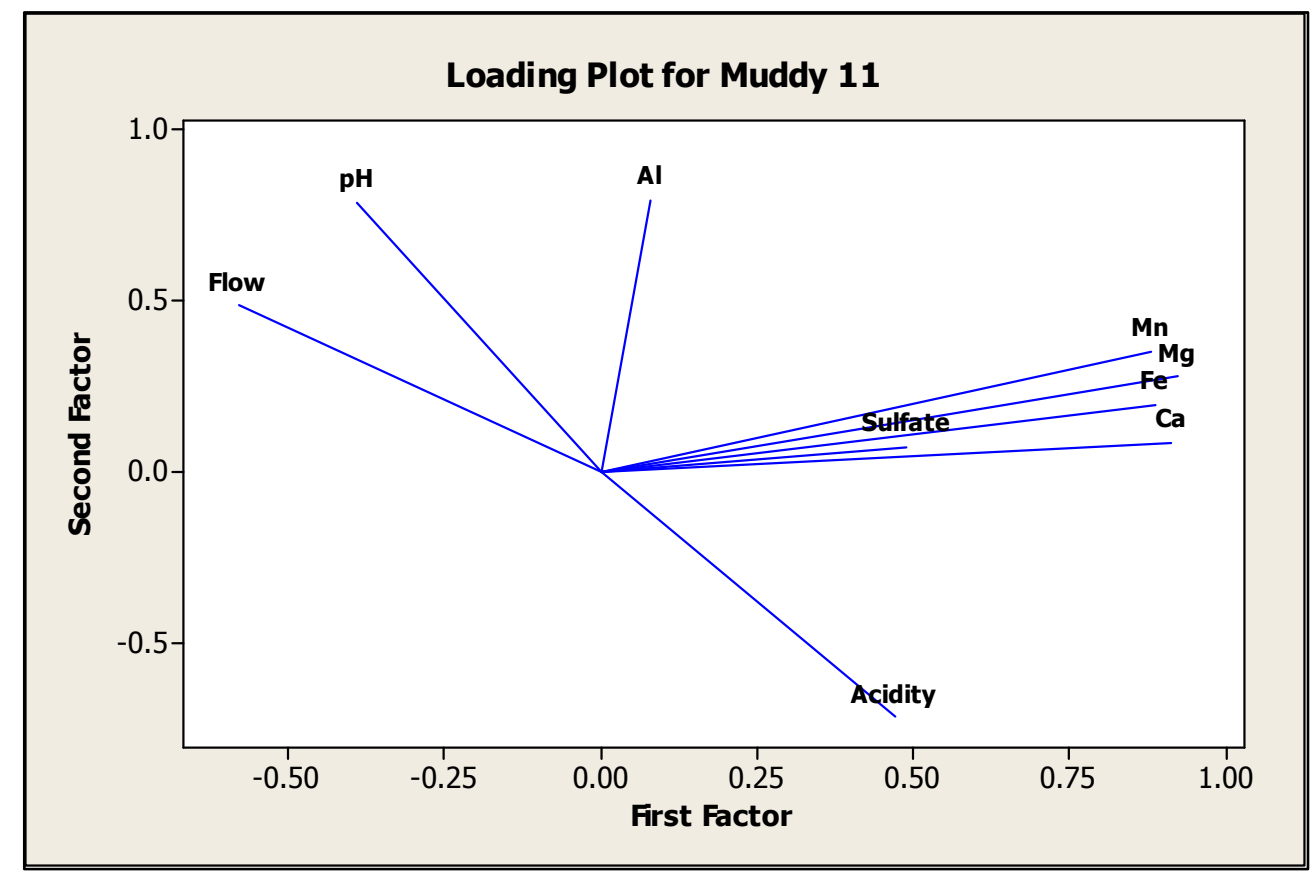

Fig 3-11. FA results for Muddy 11. Direction of lines indicates the loading of a parameter on the first or second component. Length of the lines indicates parameter magnitude. Acidity and flow show an opposite relationship to one another, as do pH and acidity. 


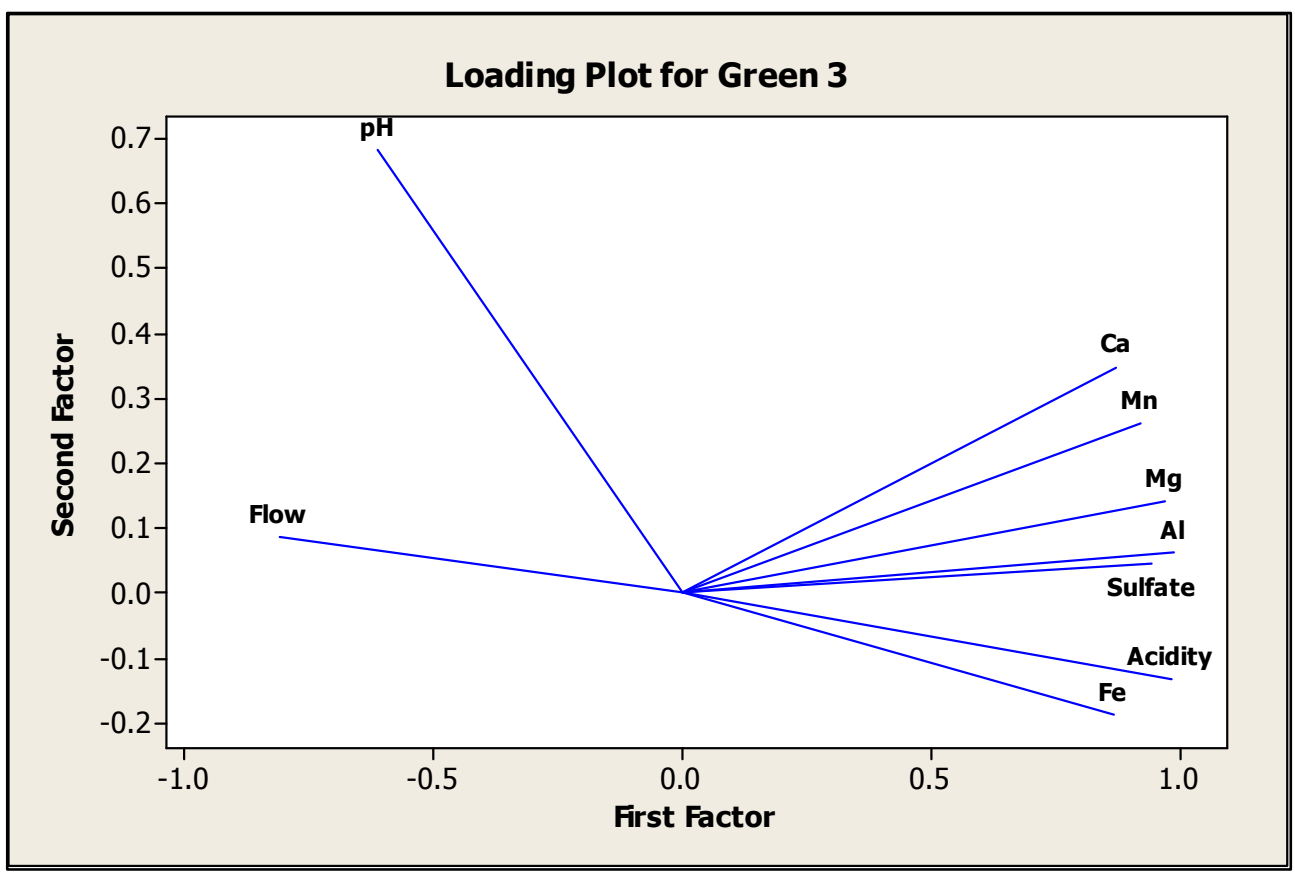

Fig 3-12. FA results for Green 3. Direction of lines indicates the loading of a parameter on the first or second component. Length of the lines indicates parameter magnitude. Acidity and flow show an opposite relationship to one another, as do pH and acidity.

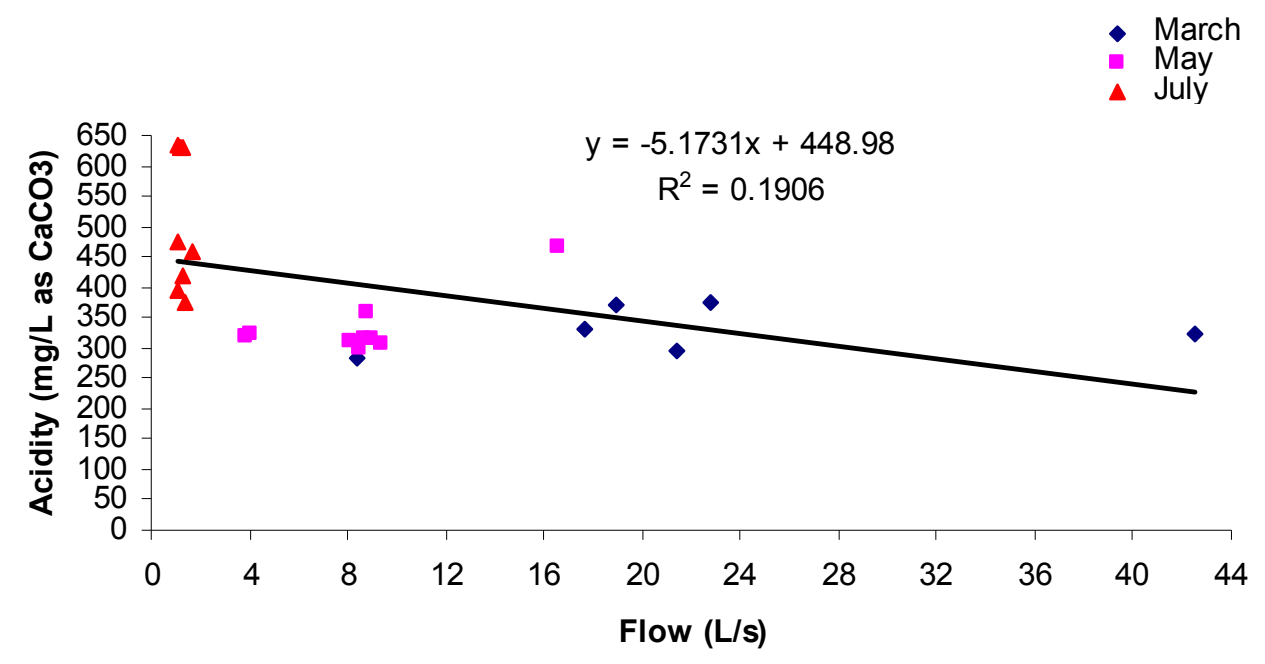

Fig. 3-13. Relationship between flow and acidity for Fickey 5. The slope of the regression line is negative, showing an inverse relationship between flow and acidity. 


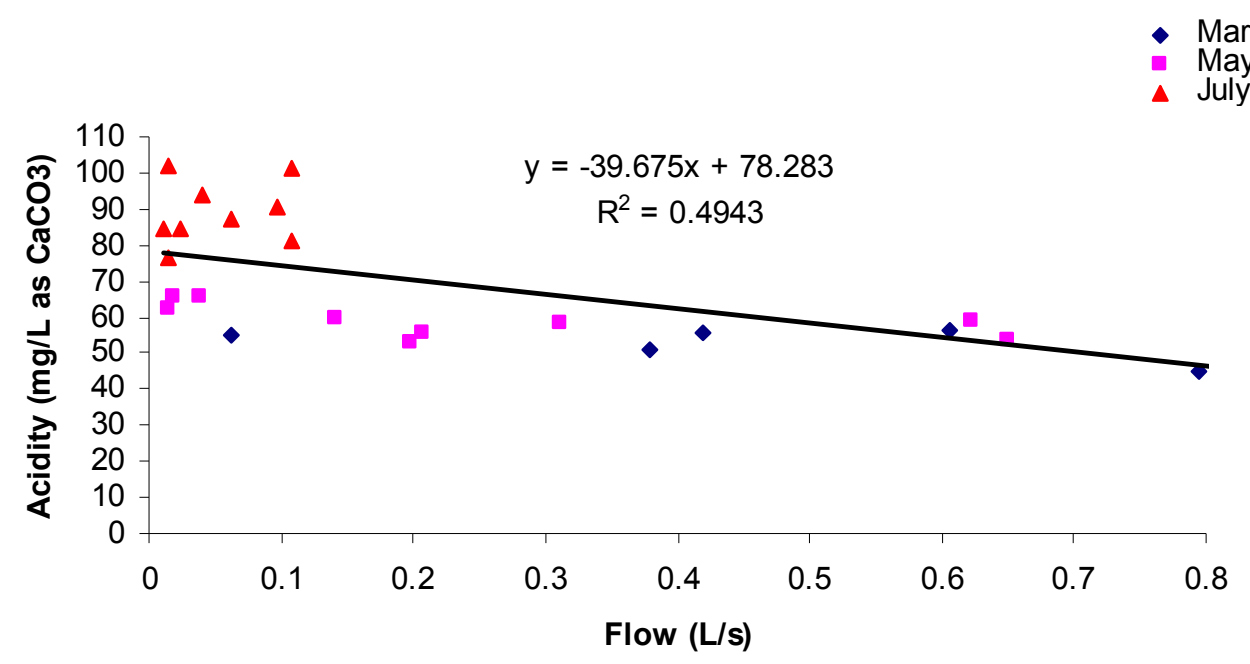

Fig. 3-14. Relationship between flow and acidity for Fickey 6. The slope of the regression line is negative, showing an inverse relationship between flow and acidity.

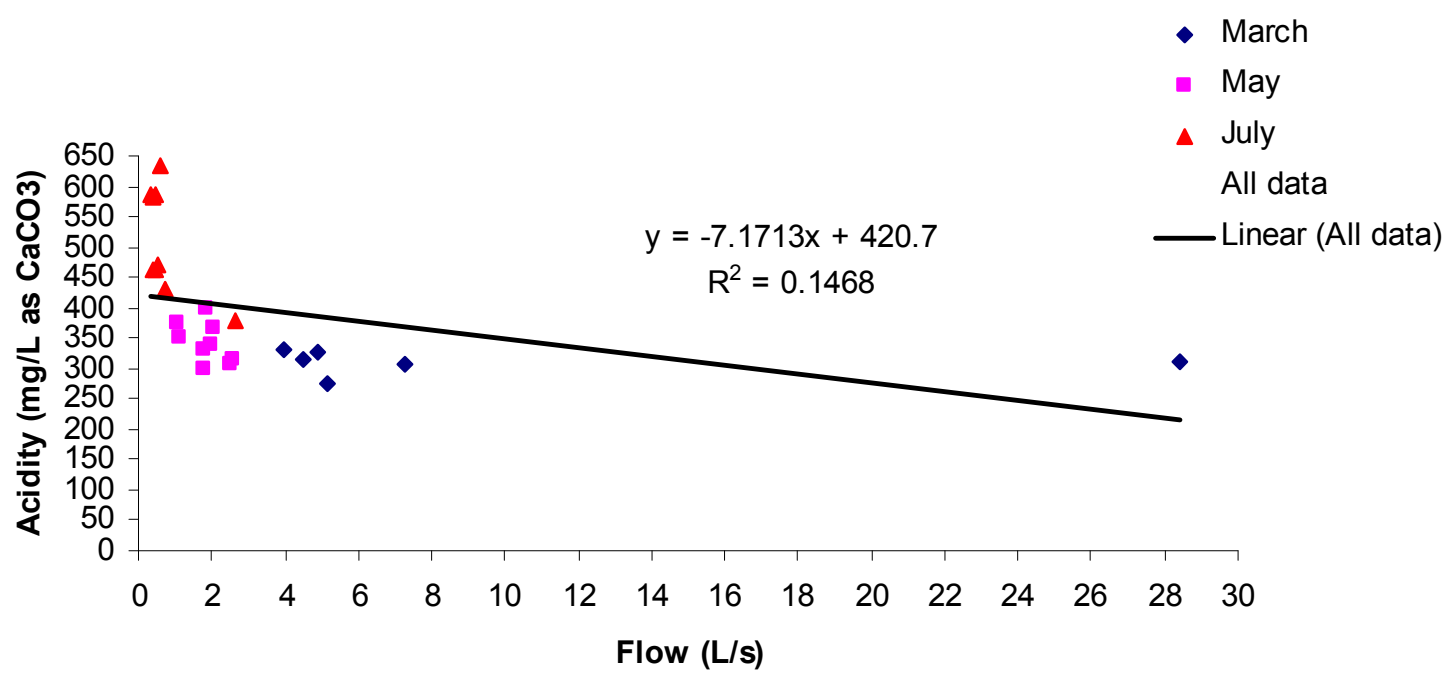

Fig 3-15. Relationship between flow and acidity for Fickey 7. The slope of the regression line is negative, showing an inverse relationship between flow and acidity. 


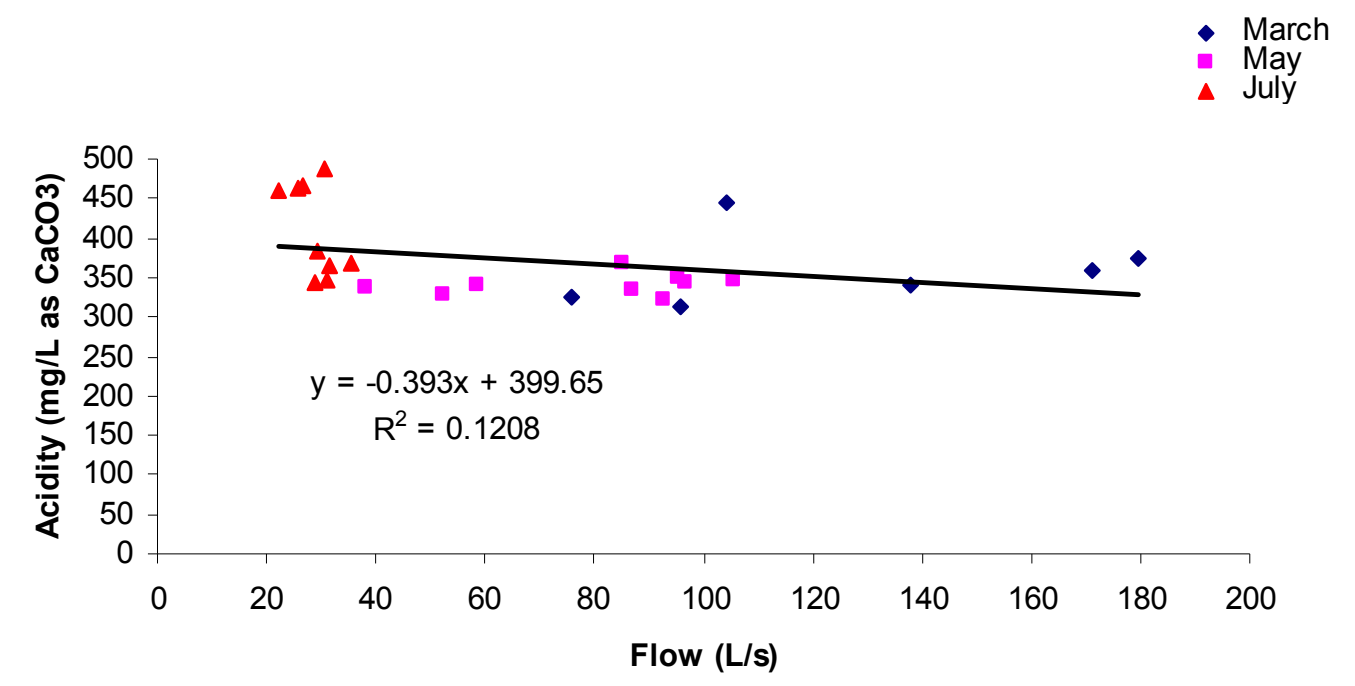

Fig 3-16. Relationship between flow and acidity for Muddy 11. The slope of the regression line is negative, showing an inverse relationship between flow and acidity.

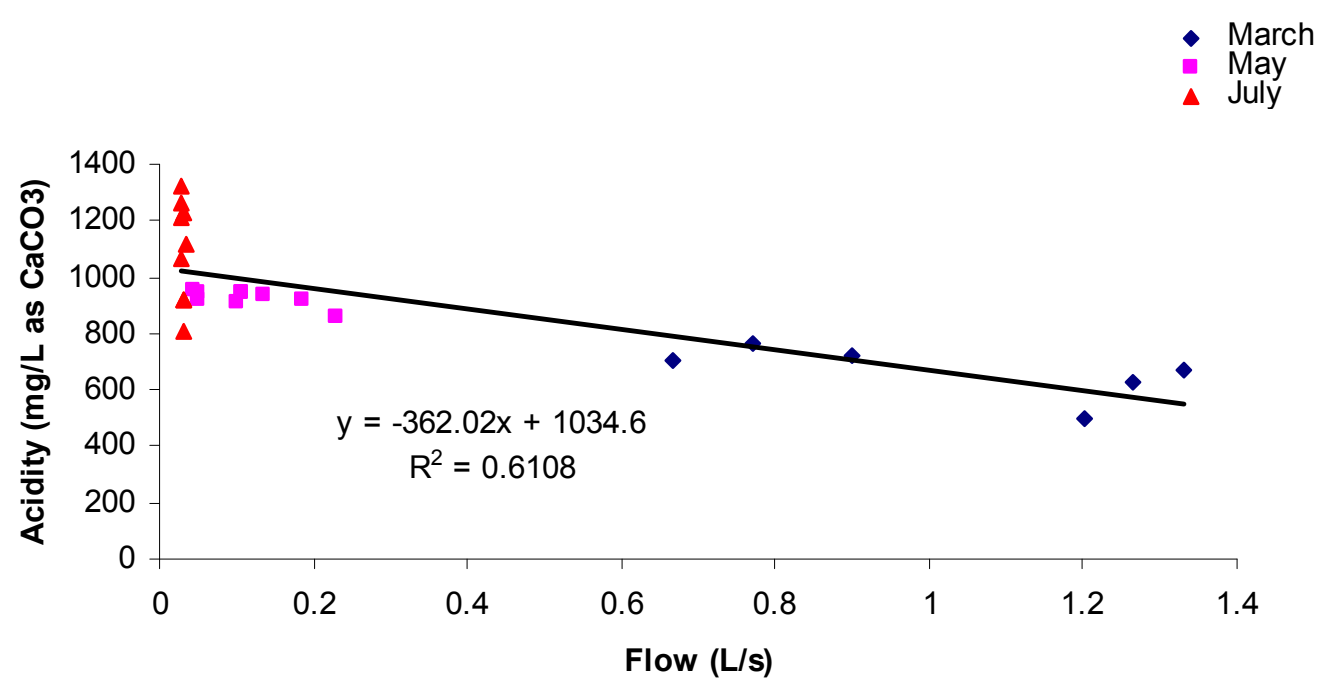

Fig 3-17. Relationship between flow and acidity for Green 3. The slope of the regression line is negative, showing an inverse relationship between flow and acidity. 

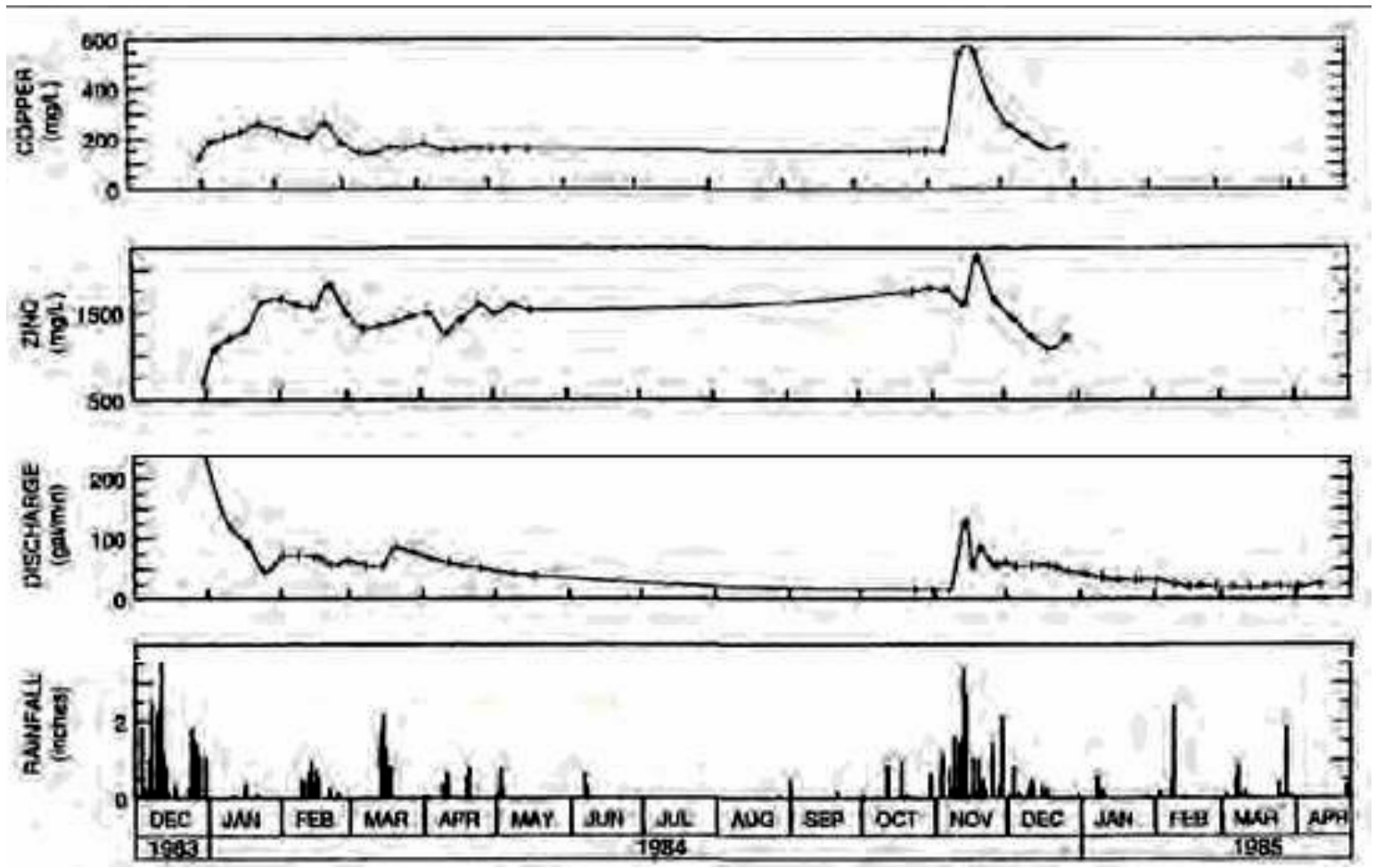

Fig. 3-18. $\mathrm{Cu}$ and $\mathrm{Zn}$ concentrations and discharge for Richmond mine effluent at Iron Mountain, CA with rainfall history at nearby Shasta Dam (from Alpers et al., 1992). 

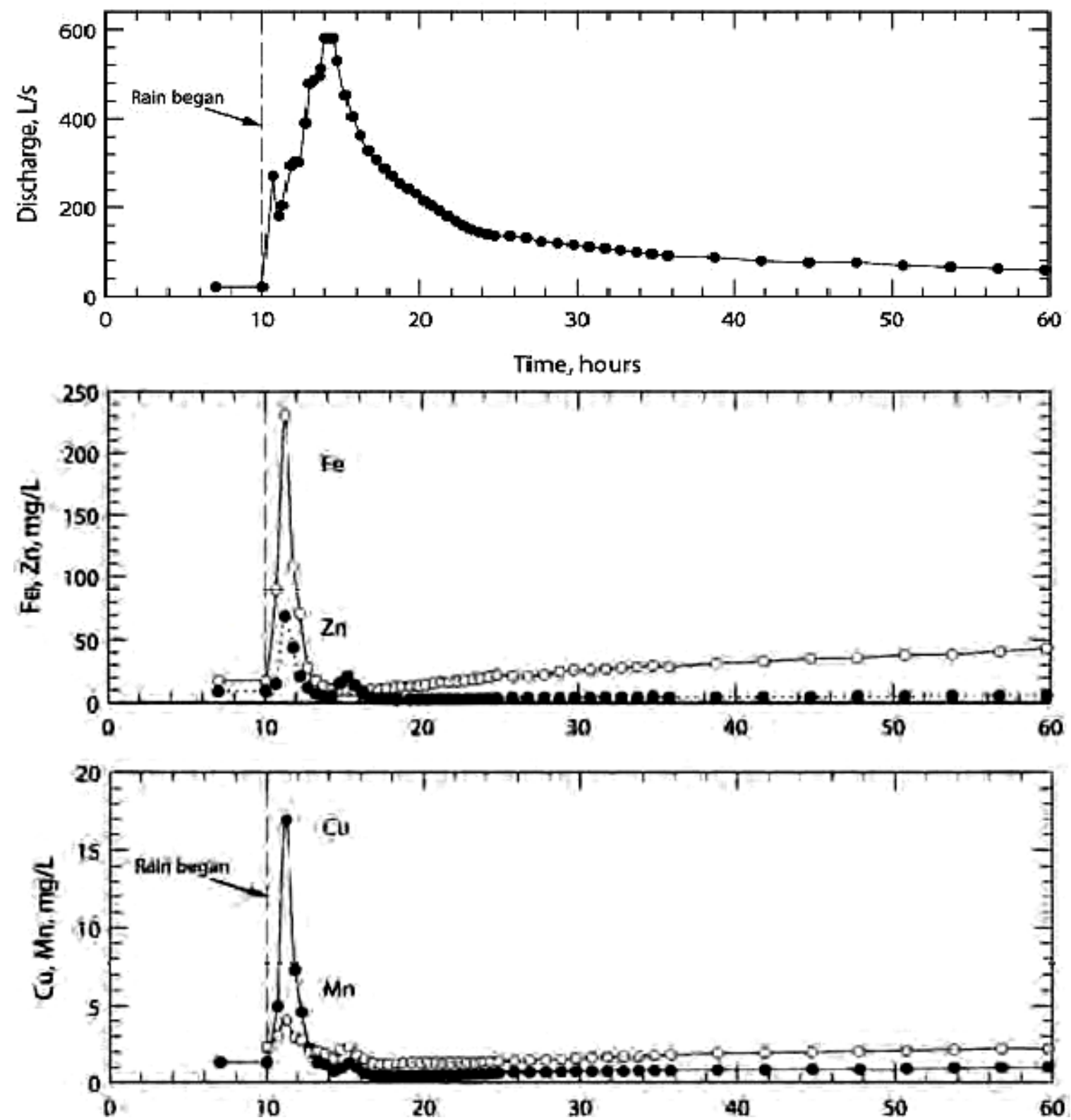

Fig. 3-19. Discharge, $\mathrm{Fe}, \mathrm{Zn}, \mathrm{Cu}$, and $\mathrm{Mn}$ concentrations in Contrary Creek during the rainstorm event of September 12-14, 1978 (modified from Dagenhart, 1980). 


\section{APPENDIX A: SUMMARY OF DECAY RATES}

\begin{tabular}{|c|c|c|c|c|c|}
\hline Author & Acidity & $\mathrm{Fe}$ & $\overline{A l}$ & SO4 & $\mathrm{Ca}$ \\
\hline $\begin{array}{l}\text { Mack } \\
(2007)\end{array}$ & $2.0 \% / y r$ & $2.1 \% / y r$ & $\begin{array}{c}1.6 \% / y r \\
.\end{array}$ & $1.4 \% / y r$. & $\begin{array}{c}1.4 \% / \mathrm{yr} \\
.\end{array}$ \\
\hline $\begin{array}{l}\text { Demchak et } \\
\text { al. (2001) }\end{array}$ & -- & -- & -- & $2.19 \% / y r$ & -- \\
\hline $\begin{array}{c}\text { Ziemkiewic } \\
\text { z (1994) }\end{array}$ & -- & -- & -- & $2.0 \% / y r$. & -- \\
\hline $\begin{array}{l}\text { Wood et al. } \\
\text { (1999) }\end{array}$ & -- & -- & -- & $\begin{array}{c}3.34 \% / y r \\
.\end{array}$ & -- \\
\hline $\begin{array}{l}\text { Koryak et } \\
\text { al. (2004) }\end{array}$ & $\begin{array}{c}1.63 \% / y r \\
.\end{array}$ & $2.0 \% / y r$ & -- & -- & -- \\
\hline $\begin{array}{l}\text { McDonoug } \\
\mathrm{h} \text { et al. } \\
\text { (2005) }\end{array}$ & -- & $1.8 \% / y r$ & -- & $2.0 \% / y r$. & -- \\
\hline $\begin{array}{l}\text { Richard } \\
\text { Mine }\end{array}$ & $4.9 \% / y r$ & $2.6 \% / y r$ & $2.1 \% / y r$ & -- & -- \\
\hline
\end{tabular}




\section{APPENDIX B: SIGNIFICANCE MATRICES FOR FLOW AND ACIDITY}

Matrix of significance for flow values of each sampling week. All values less than 0.05 are significantly different.

\begin{tabular}{ccccccccc}
\hline Week/Week & March, \#1 & March, \#2 & May, \#1 & May, \#2 & May, \#3 & July, \#1 & July, \#2 & July, \#3 \\
\hline March, \#1 & 1 & 0.0035 & 0.3404 & 0.1938 & 0.0006 & $<.0001$ & $<.0001$ & $<.0001$ \\
March, \#2 & 0.0035 & 1 & 0.0001 & $<.0001$ & $<.0001$ & $<.0001$ & $<.0001$ & $<.0001$ \\
May, \#1 & 0.3404 & 0.0001 & 1 & 0.727 & 0.011 & 0.0004 & 0.0003 & $<.0001$ \\
May, \#2 & 0.1938 & $<.0001$ & 0.727 & 1 & 0.0271 & 0.0012 & 0.0009 & 0.0003 \\
May, \#3 & 0.006 & $<.0001$ & 0.011 & 0.0271 & 1 & 0.2719 & 0.2377 & 0.1408 \\
July, \#1 & $<.0001$ & $<.0001$ & 0.0004 & 0.0012 & 0.2719 & 1 & 0.9339 & 0.7049 \\
July, \#2 & $<.0001$ & $<.0001$ & 0.0003 & 0.0009 & 0.2377 & 0.9339 & 1 & 0.7673 \\
July, \#3 & $<.0001$ & $<.0001$ & $<.0001$ & 0.0003 & 0.1408 & 0.7049 & 0.7673 & 1 \\
\hline
\end{tabular}

Matrix of significance for acidity values of each sampling week. All values less than 0.05 are significantly different.

\begin{tabular}{ccccccccc}
\hline Week/Week & March, \#1 & March, \#2 & May, \#1 & May, \#2 & May, \#3 & July, \#1 & July, \#2 & July, \#3 \\
\hline March, \#1 & 1 & 0.9643 & 0.0065 & 0.0164 & 0.003 & $<.0001$ & $<.0001$ & $<.0001$ \\
March, \#2 & 0.9643 & 1 & 0.0057 & 0.0146 & 0.0027 & $<.0001$ & $<.0001$ & $<.0001$ \\
May, \#1 & 0.0065 & 0.0057 & 1 & 0.7327 & 0.7997 & 0.0552 & $<.0001$ & $<.0001$ \\
May, \#2 & 0.0164 & 0.0146 & 0.7327 & 1 & 0.5519 & 0.0246 & $<.0001$ & $<.0001$ \\
May, \#3 & 0.003 & 0.0027 & 0.7997 & 0.5519 & 1 & 0.095 & $<.0001$ & $<.0001$ \\
July, \#1 & $<.0001$ & $<.0001$ & 0.0552 & 0.0246 & 0.095 & 1 & 0.0004 & $<.0001$ \\
July, \#2 & $<.0001$ & $<.0001$ & $<.0001$ & $<.0001$ & $<.0001$ & 0.0004 & 1 & $<.0001$ \\
July, \#3 & $<.0001$ & $<.0001$ & $<.0001$ & $<.0001$ & $<.0001$ & $<.0001$ & $<.0001$ & 1 \\
\hline
\end{tabular}




\section{APPENDIX C: MINE CHARACTERISTICS}

\begin{tabular}{|c|c|c|}
\hline Discharge Point & $\begin{array}{l}\text { Mine Name } \\
\text { Kimberly }\end{array}$ & $\begin{array}{c}\text { Year } \\
\text { closed } \\
1955\end{array}$ \\
\hline Bull 2 & Roxy Ann & 1957 \\
\hline Bull 3 & Roxy Ann & 1957 \\
\hline Bull 4 & Sherrey & 1955 \\
\hline Bull 5 & Marys & 1955 \\
\hline Cheat 2 & Morgantown North D & 1935 \\
\hline Cheat 5 & Canyon & 1940 \\
\hline Cheat 6 & Mountain Run & 1952 \\
\hline Cheat PA 1 & Morgantown North B & 1935 \\
\hline Fickey 1 & Valley Point C & 1945 \\
\hline Fickey 5 & Valley Point K & 1950 \\
\hline Fickey 6 & Valley Point $\mathrm{L}$ & 1950 \\
\hline Fickey 7 & Valley Point T & 1950 \\
\hline Fickey 8 & Tri State & 1952 \\
\hline Fickey 9 & Tri State 1 & 1945 \\
\hline Glade 1 & Liston & 1955 \\
\hline Glade 2 & Valley Point $F$ & 1950 \\
\hline Glade 3 & Valley Point G & 1950 \\
\hline Glade 4 & Valley Point A & 1950 \\
\hline Glade 5 & Valley Point A & 1950 \\
\hline Greens 1 & Pleasant & 1945 \\
\hline Greens 2 & Ricks & 1945 \\
\hline Greens 3 & Lowery & 1950 \\
\hline Lynn 1 & Hollow & 1943 \\
\hline Lynn 2 & Canyon & 1935 \\
\hline Lynn 3 & Canyon & 1935 \\
\hline Martin 2 & $\mathrm{Me}$ & 1955 \\
\hline Martin 3 & $\mathrm{Me}$ & 1955 \\
\hline Middle 1 & Mountain Run & 1952 \\
\hline Muddy 2, Seep \#1 & Cuzzart C & 1940 \\
\hline Muddy 2, Seep \#2 & Cuzzart C & 1940 \\
\hline Muddy 2, Seep \#3 & Cuzzart C & 1940 \\
\hline Muddy 2, Seep \#4 & Cuzzart C & 1940 \\
\hline Muddy 3 & Shermike & 1935 \\
\hline Muddy 5 & Gloria & 1950 \\
\hline Muddy 6 & Cuzzart B & 1945 \\
\hline Muddy 7 & Cuzzard D & 1945 \\
\hline Muddy 9 & Tri State & 1952 \\
\hline Muddy 10 & Short & 1940 \\
\hline Muddy 11 & Ruthbell 3 & 1943 \\
\hline
\end{tabular}

\begin{tabular}{|c|c|c|c|}
\hline $\begin{array}{l}\text { Coal } \\
\text { seam }\end{array}$ & $\begin{array}{l}\text { Mine size } \\
\text { (ha) }\end{array}$ & Lat & Long \\
\hline UF & 21 & 3934.646 & 7946.521 \\
\hline UF & 923 & 3933.861 & 7946.674 \\
\hline UF & 923 & 3933.398 & 7946.721 \\
\hline UF & 282 & 393325 & 794525 \\
\hline UF & 58 & 3933.567 & 7944.977 \\
\hline$P$ & 131 & 3943.041 & 7952.758 \\
\hline$P$ & 448 & 3940.254 & 7954.916 \\
\hline UF & 311 & 3935.825 & 7946.284 \\
\hline$P$ & 63 & 3944.817 & 7952.991 \\
\hline UF & 28 & 3934.807 & 7937.903 \\
\hline UF & 38 & 3933.881 & 7938.518 \\
\hline UF & 75 & 3933.776 & 7938.549 \\
\hline UF & 60 & 3933.687 & 7938.460 \\
\hline UF & 78 & 3933.386 & 7938.557 \\
\hline UF & 47 & 3933.077 & 7938.059 \\
\hline UF & 26 & 3935.273 & 7938.121 \\
\hline UF & 52 & 3935.055 & 7938.209 \\
\hline UF & 69 & 3934.969 & 7938.293 \\
\hline UF & 156 & 3934.433 & 7939.933 \\
\hline UF & 156 & 393335 & 793830 \\
\hline UF & 33 & 3929.374 & 7943.976 \\
\hline UF & 42 & 3929.570 & 7943.269 \\
\hline UF & 88 & 392943.7 & 794332 \\
\hline$P$ & 34 & 3940.66 & 7954.33 \\
\hline$P$ & 448 & 3940.256 & 7954.557 \\
\hline$P$ & 448 & 3940.843 & 7953.947 \\
\hline UF & 11 & 39.55 & 79.65 \\
\hline UF & 11 & 3933.204 & 7938.233 \\
\hline UF & 310 & 3934.839 & 7947.291 \\
\hline UF & 72 & 393521.3 & 793546. \\
\hline UF & 72 & 393516.8 & 793540. \\
\hline UF & 72 & 393512.9 & 793540. \\
\hline UF & 72 & 393530.4 & 793540. \\
\hline UF & 278 & 3935.376 & 7936.738 \\
\hline UF & 148 & 3934.848 & 7936.942 \\
\hline UF & 98 & 3934.710 & 7939.548 \\
\hline UF & 86 & 3934.273 & 7937.317 \\
\hline UF & 78 & 3933.40 & 7937.89 \\
\hline UF & 121 & 3933.082 & 7938.004 \\
\hline UF & 78 & 3932.53 & 7937.78 \\
\hline
\end{tabular}




\section{APPENDIX D: WATER CHEMISTRY FOR 40 MINE SITES}

\begin{tabular}{|c|c|c|c|c|c|c|c|c|c|c|c|c|c|c|c|c|c|c|c|c|c|c|c|c|c|c|c|c|c|c|c|c|c|c|}
\hline & & & & & & & $\mathrm{pH}$ & & & & & & & & & & & & & & & & & & & & & & & & & & & \\
\hline Site & 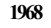 & & 00 & 6 & 7 & 1968 & & & 2006 & 2007 & 1968 & 980 & & 2006 & 2007 & 1968 & & & 2006 & 2007 & 1968 & 1980 & & 2006 & 2007 & 1968 & 2000 & 2006 & 2 & 1968 & 1980 & 20002 & & \\
\hline 111 & 140 & & 72 & 105 & 47 & 24 & & 29 & 26 & 25 & 2800 & & 1401 & 721 & 487 & 800 & & 206 & 162 & 94 & 260 & & 94 & 45 & 28 & 352 & 120 & 76 & 54 & 750 & & 1480 & 70 & ) \\
\hline 112 & 15 & & 61 & 48 & 33 & 24 & & & 26 & 24 & 1906 & & & 46 & 541 & 39 & & & 64 & & & & & & 28 & 664 & & 83 & 78 & 561 & & H4 & & 312 \\
\hline Bلll 3 & 72 & & 64 & 6 & 1 & 3.2 & & 5 & 3.4 & 3.4 & 640 & & 122 & & 164 & 57 & & & & 92 & 37 & & & & & 64 & 87 & 3 & 62 & 826 & & 40 & 30 & 80 \\
\hline Bill 4 & 42 & 106 & 171 & 6 & 38 & 3.3 & 22 & 3 & 3.2 & 25 & 250 & 360 & 530 & 364 & 391 & 82 & 85 & 48 & 17 & 41 & 1 & 3 & 4 & 30 & 21 & 260 & 453 & 109 & 75 & 556 & 00 & 199 & 37 & 29 \\
\hline Bull 5 & 212 & & 356 & 4 & 1 & 29 & & 3 & 28 & 26 & 1370 & & 336 & 56 & 322 & 624 & & 15 & 4 & 9 & 67 & & 36 & 26 & 22 & o/ & 00 & $1 /$ & 69 & 3276 & & 650 & 70 & 02 \\
\hline eat 2 & 11 & & 15 & 6 & 8 & 3.3 & & 22 & 25 & 24 & 1061 & & 1033 & 865 & 870 & 258 & & 203 & 197 & 214 & 85 & & 54 & 55 & 45 & 125 & B & 179 & 188 & 9750 & & 72 & 95 & 845 \\
\hline eat 5 & 19 & 8 & 38 & 163 & 124 & 26 & 26 & 3. & 27 & 26 & 1825 & 2 & 104 & 366 & $T$ & 458 & 2 & 2 & 62 & & 101 & 19 & & 14 & 1 & & & & 79 & 392 & 1100 & 19 & 44 & נד \\
\hline eat 6 & 296 & & 144 & 14 & 5 & 26 & & 28 & 5.0 & 27 & 1450 & & 487 & 331 & 308 & 28 & & 48 & 30 & 23 & 104 & & 46 & 33 & 22 & 64 & 56 & 0 & 39 & 1612 & & 775 & 90 & 72 \\
\hline PAl & 299 & & 19 & 22 & 17 & 3.3 & & 3.7 & 27 & 28 & 2457 & & 563 & 30 & 216 & 49 & & $\pi$ & 16 & & 141 & & & 15 & 16 & 160 & 79 & 59 & 66 & 2602 & & 833 & & 29 \\
\hline key & 23 & & 428 & 3 & 1 & 3 & & 3 & 3.1 & 28 & 3270 & & 154 & 95 & 563 & 672 & & & 134 & 19 & 180 & & & 91 & 59 & 224 & 172 & 57 & 64 & 3744 & & 883 & 20 & ) \\
\hline cey & 34 & 4 & 5 & 481 & $x$ & 3.1 & 25 & 3.8 & 29 & 27 & 515 & 460 & 697 & 57 & 451 & 88 & 42 & 43 & 22 & 35 & 24 & 29 & & 48 & 41 & 82 & 150 & 135 & 129 & 585 & 500 & 620 & & 204 \\
\hline cy & 4 & 30 & 42 & 4 & 3 & 24 & 23 & 3.0 & 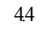 & 4.1 & 1300 & 425 & 118 & of & 97 & 288 & 4 & 13 & 10 & & 12 & 34 & & & & 128 & $30 /$ & 100 & 26 & 1456 & 900 & 849 & 010 & 106 \\
\hline key & 11 & & 212 & 45 & $\theta$ & 28 & & 22 & 3.1 & 27 & 1670 & & 1086 & 428 & 391 & 237 & & 19 & 11 & 3 & 157 & & 78 & 62 & 46 & 154 & 194 & 73 & 164 & 007 & & 1118 & 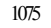 & 1153 \\
\hline $\mathrm{key}$ & 186 & 4 & 15 & 110 & 37 & 3 & 23 & 3.5 & 26 & 24 & 1505 & 1225 & 390 & 86 & 457 & 288 & 81 & 17 & 26 & 23 & 84 & 0 & 3 & 39 & 33 & 168 & 185 & 50 & 62 & 872 & 2000 & 996 & 42 & 887 \\
\hline $\mathrm{ke}$ & 64 & & 72 & 4 & 11 & 28 & & 26 & 28 & 25 & 1920 & & 498 & 69 & 869 & 378 & & 16 & 115 & 122 & 88 & & 4 & 85 & 84 & 44 & 83 & 2 & 122 & 501 & & 1311 & 05 & 1495 \\
\hline a & 5 & & 15 & 4 & 38 & 3.1 & & 3. & 36 & 3.1 & 1705 & & 151 & 65 & 10 & 228 & & & 3 & & 146 & & & & & 237 & & 9 & 23 & 26 & & 170 & & 71 \\
\hline a & 15 & & 72 & 34 & 19 & 3.6 & & 4 & 3. & 3.0 & 390 & & 179 & 136 & 328 & 53 & & 17 & & & 29 & & & & 3 & & & & 78 & Le & & 20 & & 725 \\
\hline hade? & 42 & & 42 & 15 & 3 & 28 & & & 4.5 & 4.3 & 675 & & 412 & 6 & 88 & 48 & & 3 & 2 & & 65 & & & & 1 & 214 & 72 & 16 & I & 118 & & 368 & & 80 \\
\hline Cade & 72 & 4 & 30 & 8 & 6 & 29 & 21 & & 32 & 7 & 1660 & 1250 & 23 & 348 & 92 & 39 & 12 & 3 & & & 28 & 43 & & & 36 & 178 & 214 & 174 & 159 & 50 & 1800 & 2 & 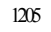 & 51244 \\
\hline Gade & 18 & 15 & 30 & & 8 & 24 & 22 & 3. & 3.6 & 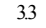 & 1765 & 0 & 383 & 146 & 160 & 15 & 16 & 4 & & & 150 & 13 & & & & 378 & 300 & 286 & 30 & 4 & 2 & 79 & 2200 & 2158 \\
\hline ens & 23 & 8 & 95 & 12 & 5 & 27 & 29 & 2 & 28 & 7 & 945 & 45 & 702 & 68 & 244 & 215 & 130 & 117 & & & 53 & 2 & & 10 & 10 & 76 & & 24 & 25 & 600 & 1 & 132 & 3 & 91 \\
\hline$a n$ & 4 & & 4 & 4 & $\mathrm{p}$ & 4 & & 4. & 5.4 & 5.1 & 8 & & . & 6 & 6 & 1 & & 6 & & & & & & 0.3 & 0.1 & & & & & 14 & & 42 & & 16 \\
\hline s & 15 & 30 & 114 & 27 & 6 & 25 & 3 & 21 & 25 & 27 & 1504 & 830 & 1932 & 926 & 1000 & 288 & 180 & 203 & 197 & 232 & 108 & 5 & & 69 & 88 & 98 & 30 & 42 & 61 & 1508 & 700 & 1521 & ) & 1000 \\
\hline 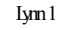 & 38 & 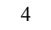 & 8 & 5 & 4 & 28 & 24 & 3. & 3.0 & 28 & 368 & 406 & 102 & 15 & 40 & 495 & 90 & 4 & 8 & & 100 & 4 & & 26 & ( & 92 & 66 & 3 & 81 & 861 & 0 & 240 & 76 & 556 \\
\hline ? & 14 & & 1 & 73 & $Q$ & 3 & 2 & 2 & & 29 & 2690 & 605 & 434 & 249 & 212 & 131 & 90 & 49 & 26 & & 302 & 4 & & & 1 & 81 & 04 & 83 & 88 & 105 & 1 & 745 & 10 & 573 \\
\hline & & 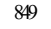 & 1 & 15 & $\gamma$ & 3 & 24 & & & 27 & 4988 & 1075 & 237 & 57 & 504 & 477 & 180 & & 135 & 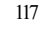 & 532 & 12 & & & 3 & & & 32 & 157 & 2593 & 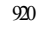 & 619 & 75 & 1237 \\
\hline $\mathrm{N}$ & & 4 & 14 & 15 & 2 & 2 & 24 & & & 11 & 2315 & 3 & 135 & 146 & 79 & 2 & $n$ & 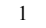 & 16 & 10 & 10 & & & & & & & & 12 & 90 & & 87 & 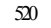 & 477 \\
\hline M & 23 & & 216 & 4 & 1 & 3 & & 5 & & 5 & 490 & & 25 & 1 & 0 & 105 & & $\pi$ & 1 & 0.2 & 1 & & & & 0.2 & 52 & 346 & & & 20 & & 1543 & & 22 \\
\hline blle 1 & 66 & 2 & 144 & & 6 & 2 & 23 & 3 & & 26 & 917 & 515 & 291 & & 34 & 16 & & 23 & 1 & & 46 & 3 & 3 & & 19 & 156 & & 42 & 45 & 105 & & 5 & & 407 \\
\hline 1 & & 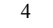 & 15 & 80 & 18 & 2 & 21 & 5 & 3. & 3.1 & 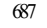 & 41 & 86 & 119 & & 1 & 12 & 7 & & & 14 & 1 & & & & & & 143 & 108 & 88 & & 46 & & 541 \\
\hline & & 4 & 15 & 4 & 5 & & 21 & 5 & & 29 & 7 & 41 & 86 & 100 & & 1 & 12 & & & & & & & & & & & 15 & 22 & & & 46 & & 09 \\
\hline & & 4 & 15 & $\varepsilon$ & 3 & & 2 & 5 & & 3.1 & & 41 & 86 & 12 & 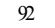 & 1 & 12 & & & & & & & & & & & 39 & 114 & 3 & & 46 & & 38 \\
\hline ty 24 & 01 & 4 & 1 & 95 & 19 & 2 & 21 & 5 & 3 & 29 & 687 & 410 & 86 & 126 & 152 & 11 & 120 & 7 & $\Delta u$ & & 4 & 10 & & & 11 & & 137 & 136 & 146 & 78 & 1 & 462 & 17 & 343 \\
\hline Maddy & 15 & 303 & 114 & 4 & 1 & 3. & 3.4 & 5.3 & 5 & 5.2 & 170 & 110 & 45 & - & 2 & 640 & 60 & 10 & 0.29 & 0 & 6 & 3 & & 12 & 0.1 & 180 & 32 & 24 & 28 & 377 & 400 & 111 & 84 & 89 \\
\hline Murdty & 15 & & 15 & 4 & $\mathrm{p}$ & 65 & 5.5 & & 6 & 7.3 & 20 & & 3 & 5 & 2 & . & & 7 & 1 & 0 & t & & & 0.3 & 01 & 60 & 8 & 33 & 26 & 13 & & 39 & 55 & 45 \\
\hline & 4 & & 15 & 10 & 5 & 27 & & 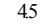 & & 64 & 4400 & & 9 & 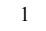 & 1 & 110 & & 5 & 0.04 & 0.09 & 266 & & & 2 & 0.01 & 1285 & 35 & 145 & 160 & 045 & & 147 & 82 & 314 \\
\hline & 5 & & 3 & 4 & $\mathrm{p}$ & 3.1 & 5.2 & & 4 & 4.2 & 520 & & 7 & 7 & 7 & 87 & & 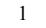 & & 0.4 & 26 & & & 5 & 0.4 & 400 & 8 & 0 & 7 & 1300 & & 15 & 24 & 28 \\
\hline & 387 & 10 & so & 34 & 3 & 29 & 22 & 2 & 2 & 27 & 3515 & 6 & 612 & 627 & 509 & 42 & 84 & 2 & 9 & 80 & 301 & 21 & 20 & $\omega$ & 58 & 200 & 194 & 150 & 151 & 1951 & & 2400 & 1170 & 670 \\
\hline & 20 & & 30 & 4 & & 29 & & J. & 3. & DKY & 1440 & & o & 32 & & 12 & & 1 & 11 & & 13 & & & 7 & & 340 & 30 & 110 & & 208 & & 150 & $0 x$ & \\
\hline adrdy 11 & 4298 & & 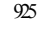 & . & & 26 & & 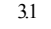 & . & 3.0 & 2140 & 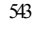 & -00 & & 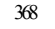 & 400 & & $10 \mathrm{E}$ & 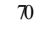 & & 108 & & & 2 & & 332 & 100 & 135 & & 2704 & & 1343 & 965 & \\
\hline
\end{tabular}

Digitally signed by John $\mathrm{H}$. Hagen

DN: $\mathrm{cn}=J$ John H. Hagen, o=West Virginia

University Libraries, ou=Acquisitions

Department, email=John.Hagen@mail. wvu.edu, $\mathrm{C}=$ US 